Portland State University

PDXScholar

1989

\title{
Chemical Modification of Skeletal Muscle Sarcoplasmic Reticulum Vesicles: A Study of Calcium Permeability
}

Janice F. Stuart

Portland State University

Follow this and additional works at: https://pdxscholar.library.pdx.edu/open_access_etds

Part of the Environmental Chemistry Commons

Let us know how access to this document benefits you.

Recommended Citation

Stuart, Janice F., "Chemical Modification of Skeletal Muscle Sarcoplasmic Reticulum Vesicles: A Study of Calcium Permeability" (1989). Dissertations and Theses. Paper 1389.

https://doi.org/10.15760/etd.1388

This Dissertation is brought to you for free and open access. It has been accepted for inclusion in Dissertations and Theses by an authorized administrator of PDXScholar. Please contact us if we can make this document more accessible: pdxscholar@pdx.edu. 
CHEMICAL MODIFICATION OF SKELETAI MUSCLE SARCOPLASMIC RETICULUM VESICLES: A STUDY OF CALCIUM PERMEABILITY

\author{
by \\ JANICE F. STUART
}

A dissertation submitted in partial fulfillment of the requirements for the degree of

\begin{abstract}
DOCTOR OF PHILOSOPHY
in

ENVIRONMENTAL SCIENCES AND RESOURCES/CHEMISTRY
\end{abstract}

Portland State University

C1989 
TO THE OFFICE OF GRADUATE STUDIES:

The members of the committee approve the dissertation of Janice F. Stuart presented May 4, 1989.

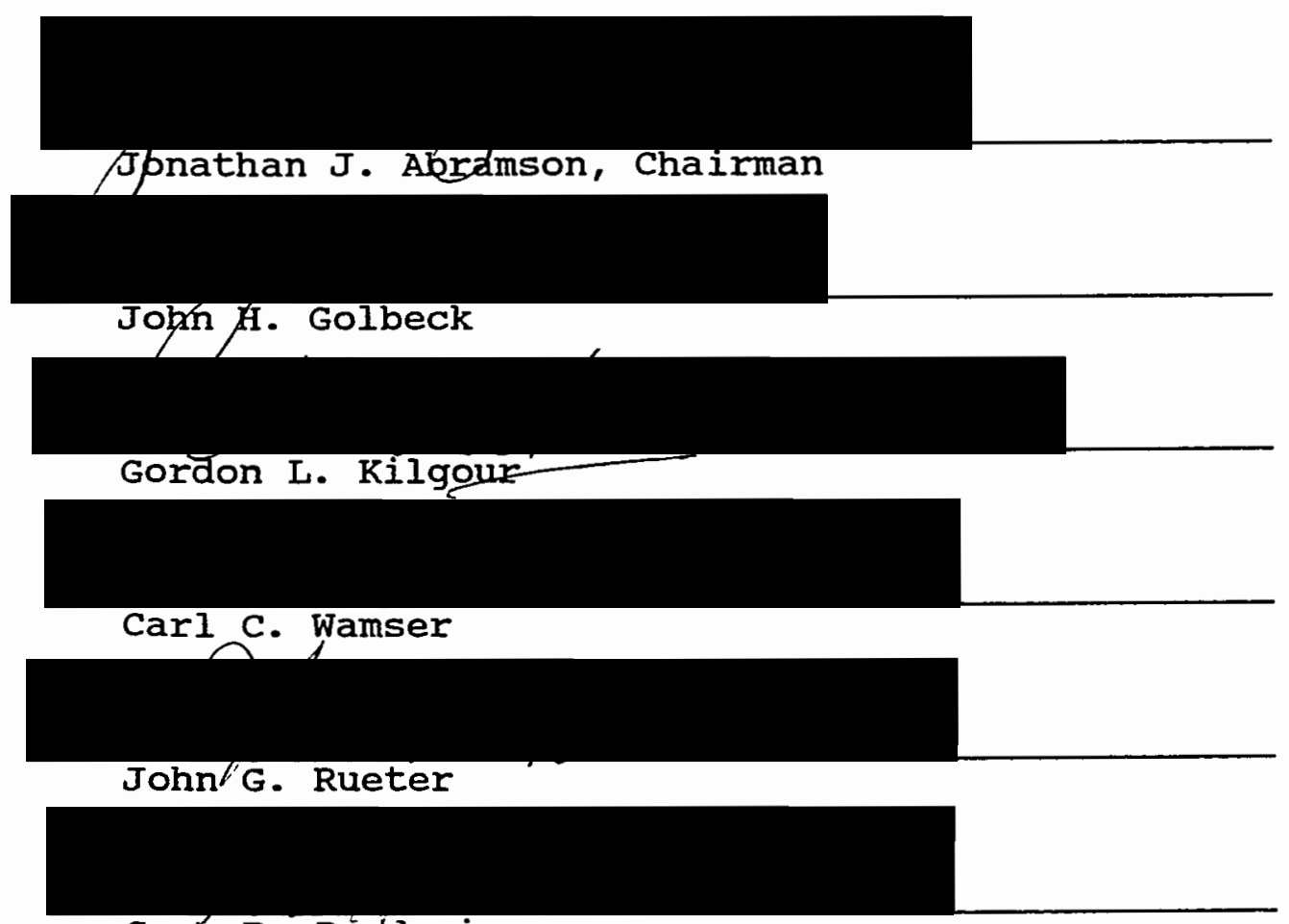

Gary R. Bródowicz,

Graduate Council Representative

APPROVED:

Pavel K. Smejtek, Director,

Environmental Sciences and Resources Program

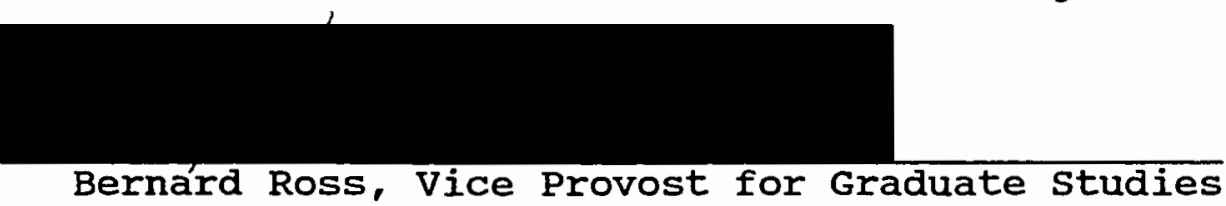


AN ABSTRACT OF THE DISSERTATION OF Janice F. Stuart for the Doctor of Philosophy in Environmental Science and Resources presented May 4, 1989.

Title: Chemical Modification of Skeletal Muscle Sarcoplasmic Reticulum Vesicles: A study of Calcium Permeability.

APPROVED BY THE MEMBERS OF THE DISSERTATION COMMITTEE:

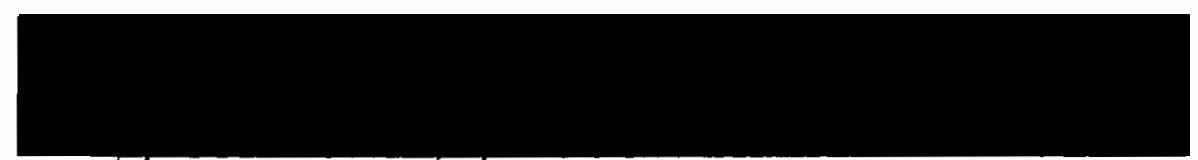

Jonathan J. Abramson, Chair

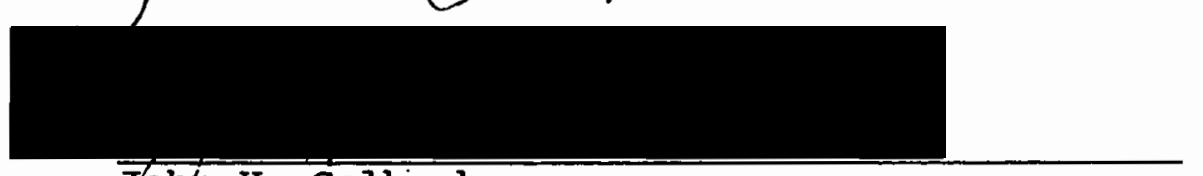

John H. Golbeck

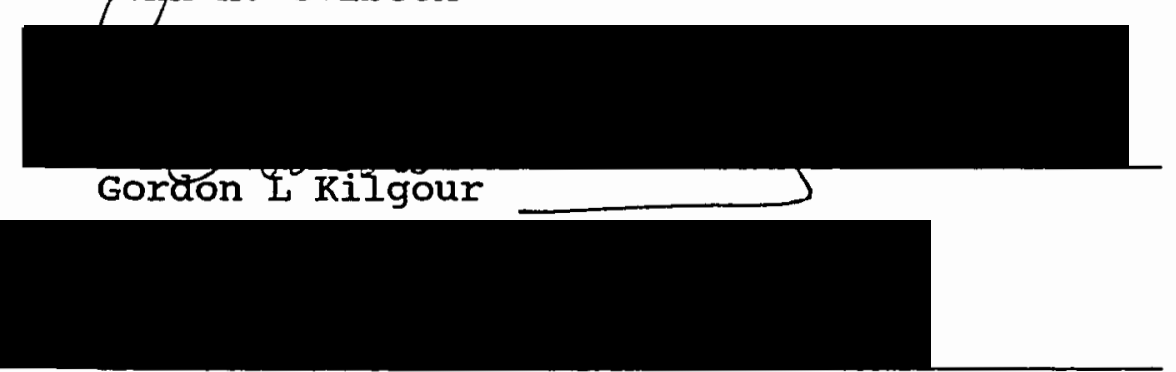

Carl c. Wamser

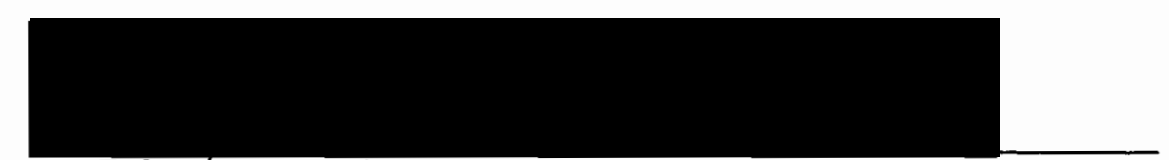

John/G. Rueter

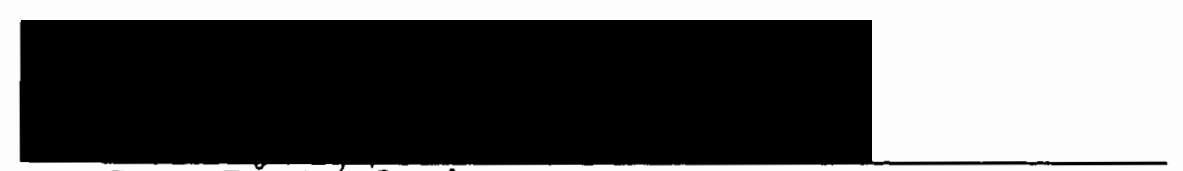

Gary R. Brodowicz 
Skeletal muscle contains an internal membrane system called the sarcoplasmic reticulum (SR) whose function is to regulate the $\mathrm{Ca}^{2+}$ concentration of the myoplasm. $\mathrm{Ca}^{2+}$ is transported into the $S R$ from the myoplasm via a $\mathrm{Ca}^{2+}$ dependent ATPase thus lowering the myoplasmic $\mathrm{Ca}^{2+}$ concentration. $\mathrm{Ca}^{2+}$ exits from the $\mathrm{SR}$ via a $\mathrm{Ca}^{2+}$ release pathway resulting in the increase of myoplasmic $\mathrm{Ca}^{2+}$. Muscles contract when the myoplasmic $\mathrm{Ca}^{2+}$ concentration is $>5 \mathrm{um}$ and relax when the $\mathrm{Ca}^{2+}$ concentration is lowered below 1 uM. The $\mathrm{Ca}^{2+}$ dependent ATPase has been extensively studied but the $\mathrm{Ca}^{2+}$ release system is less well understood.

SR vesicles release their internal $\mathrm{Ca}^{2+}$ when a reactive thiol group is oxidized (oxidation-induced $\mathrm{Ca}^{2+}$ release). It is shown in this dissertation that oxidationinduced $\mathrm{Ca}^{2+}$ release is stimulated by adenine nucleotides with an order of effectiveness of:

$$
\text { ATP }>\text { AMP-PCP > CAMP > AMP > adenine }
$$

The stimulatory effect is not dependent upon phosphorylation of a protein because AMP-PCP, a nonhydrolyzable analogue of ATP, is almost as effective as ATP in stimulating oxidation-induced $\mathrm{Ca}^{2+}$ release.

It is also shown in this dissertation that photooxidation of histidyl residues results in an increase $\mathrm{Ca}^{2+}$ permeability of the SR. Unlike oxidation-induced $\mathrm{Ca}^{2+}$ release, photooxidation-induced $\mathrm{Ca}^{2+}$ release is $\mathrm{Mg}^{2+}$ 
independent, not inhibited by ruthenium red and inhibited by adenine nucleotides. Covalent modifcation of histidyl residues with ethoxyformic anhydride results in the increased permeability of SR vesicles. similar to photooxidation-induced $\mathrm{Ca}^{2+}$ efflux, EFA-induced $\mathrm{Ca}^{2+}$ efflux is $\mathrm{Mg}^{2+}$ independent and is inhibited by ATP. The AMP-PCP protection of SR proteins from modification with EFA is similar to non-competitive inhibition with a $\mathrm{K}_{\mathrm{I}}=50 \mathrm{uM}$. The photooxidation effect is not on membrane lipids but on a protein component which may be an ion transport system, other that the $\mathrm{Ca}^{2+}$ release protein, altered in such a way that it now transports $\mathrm{Ca}^{2+}$ 
DEDICATED

to

ERIN MICHELLE BENNETT

and

JIM AND CHARLOTTE STUART 


\section{ACKNOWLEDGEMENTS}

Thanks go to many people for support they have provided during the process of obtaining my PhD. Many thanks go to Dr. Jon Abramson, my advisor, for all the help and direction he has provided. I would also like to thank the members of my committee for all their constructive critiques and careful reading of the dissertation manuscript. Thanks go to Dr. John Pooler, Emory University, for the valuable conversations we had regarding photooxidation and rose bengal. I am also eternally grateful to the Environmental science and Chemistry departments for providing financial support.

A very special thanks goes to Maria Brown and Charlotte stuart for the hours they spent typing and proofreading the dissertation manuscript. And last, but not least, I want to thank my daughter, Erin, for all the sacrifices she had to make for me to realize this goal. 
TABLE OF CONTENTS

PAGE

DEDICATION............................

ACKNOWLEDGEMENT. ........................ iv

LIST OF TABLES.........................

LIST of FIGURES........................ ix

CHAPTER

I OVERVIEW OF RELEVANT RESEARCH............ 1

Introduction................... 1

Membrances..................... 2

Calcium as an intracellular messenger... 7

Calcium ATPase in membranes......... 8

Calcium release................. 10

Calcium-incuded calcium release

Calcium release induced by amino acid modifying reagents

Isolation of SR proteins involved in $\mathrm{Ca}^{2+}$ release

overview of this dissertation........ 17

II EXPERIMENTAL METHODS AND MATERIALS........ 21

Protein preparations.............. 21

Protein isolation

Preparation of Light and Heavy SR vesicles

Protein concentration determination

Measurement of $\mathrm{Ca}^{2+}$ efflux.......... 25

Histidine modification............ 28 
ATPase activity................. 29

Gel electrophoresis............... 30

Asolectin Vesicles............... 32

Calcium uptake of rose bengal treated

SR vesicles.................... 33

singlet oxygen production........... 33

Materials..................... 34

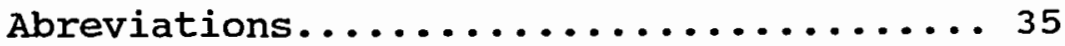

III ADENINE NUCLEOTIDES STIMULATE OXIDATION-

CALCIUM EFFLUX FROM SARCOPLASMIC RETICULUM

VESICLES.......................... 36

Summary..................... 36

Introduction................. 37

Results..................... 38

Discussion.................... 54

IV PHOTOOXIDATION OF SARCOPLASMIC RETICULUM

VESICLES......................... 59

summary........................ 59

Introduction................. 59

Results......................61

Discussion..................... 79

$\mathrm{V}$ THE ROLE OF HISTIDYL RESIDUES IN CALCIUM

EFFLUX FROM SARCOPLASMIC RETICULUM VESICLES... 86

summary ..................... 86

Introduction................. 87

Results...................... 87

Discussion..............................

VI SUMMARY AND PROJECTIONS............... 107 
REFERENCES............................... . . 124 


\section{LIST OF TABLES}

TABLE

PAGE

I Effect of Non-Adenine Nucleotides on copper/cysteine-induced calcium

efflux rate........................4 4

II Effect of various compounds on oxidationstimulated $\mathrm{Ca}^{2+}$ efflux from passively

loaded vesicles.....................443

III Effect of AsIII on oxidation and adenine nucleotide stimulation of oxidation-induced calcium efflux from actively loaded vesicles............... 53

IV Comparison of the effect of various reagents on calcium efflux rates from rose bengal treated vesicles.............67

$\mathrm{V}$ Rose bengal-induced calcium release from asolectin vesicles................ 74

VI Comparison of the effect of various reagents on calcium efflux rates from rose bengal treated vesicles.............89

VII Magnesium dependence of calcium efflux from actively loaded vesicles............. 97

VIII The effect of silver on photooxidationinduced $\mathrm{Ca}^{2+}$ release from LSR vesicles........115

IX The effect of DIDS on photooxidation-induced $\mathrm{Ca}^{2+}$ release from $\mathrm{SR}$ vesicles...............116 


\section{LIST OF FIGURES}

1. A diagram of the fluid mosaic membrane model............................ 6

2. Schematic representation of sarcoplasmic reticulum....................... 11

3. Adenine nucleotide stimulation of $\mathrm{Ca}^{2+}$ efflux release from actively loaded SR vesicles..... 40

4. Effect of AMP-PCP concentration on oxidationinduced $\mathrm{Ca}^{2+}$ efflux.................. 45

5. Magnesium dependence of oxidation-induced $\mathrm{Ca}^{2+}$ efflux.......................... 48

6. Effect of internal $\mathrm{Mg}^{2+}$ concentration on $\mathrm{Ca}^{2+}$ efflux from passively loaded sRvesicles...... 50

7. Effect of AMP-PCP on $\mathrm{Cu}^{2+}$ /cysteine-induced $\mathrm{Ca}^{2+}$ efflux measured with a $\mathrm{Ca}^{2+}$ selective electrode........................... 52

8. $\mathrm{Ca}^{2+}$ uptake and ATPase activity as a function of rose bengal................62

9. Rose bengal-induced $\mathrm{Ca}^{2+}$ efflux from actively loaded SR vesicles..............6 64

10. Concentration dependence of rose bengalinduced $\mathrm{Ca}^{2+}$ efflux..................66

11. Spectra of rose bengal and methylene blue in the presence or absence of ruthenium red..... 69

12. Detection of singlet oxygen production......71

13. Methylene blue-induced $\mathrm{Ca}^{2+}$ release........ 73

14. Comparison of rose bengal-induced $\mathrm{Ca}^{2+}$ release from HSR and LSR................76 
15. $\mathrm{Ca}^{2+}$ dependence of rose bengal-induced $\mathrm{Ca}^{2+}$ efflux........................... 78

16. Rose bengal-induced $\mathrm{sa}^{2+}$ efflux from passively loaded vesicles..............8 80

17. Absorbance spectra of histidine, tryptophan and $S R$ vesicles after photooxidation........91

18. The ${ }_{+} \mathrm{pH}$ dependence of rose bengal-induced $\mathrm{Ca}^{2+}$ efflux....................... 93

19. EFA stimulation of $\mathrm{Ca}^{2+}$ efflux from SR vesicles....................... 94

20. $\mathrm{Mg}^{2+}$ dependence of EFA-induced $\mathrm{Ca}^{2+}$ efflux... 96

21. The effect of AMP-PCP concentration on the rate of histidine modification by EFA....... 99

22. The concentration dependence of EFA modification of histidyl residues..........101

23. The effect of $\mathrm{Cs}^{+}$ions on photooxidationinduced $\mathrm{Ca}^{2+}$ release...................114

24. The effect of photooxidation on SDS-PAGE pattern of $S R$ proteins................118

25. The effect of photooxidation-induced $\mathrm{Ca}^{2+}$ release from SR vesicles using erythrosin $B$

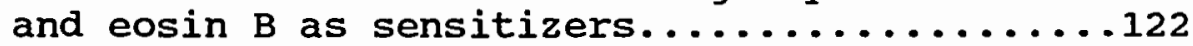


CHAPTER I

OVIRVIEW OF RELEVANT RESEARCH

\section{INTRODUCTION}

Living cells, in simple bacteria to complex organisms, have a need to sense and respond to their environment. If the environmental signals are right, the healthy cells will respond to produce the desired action. There are many different signals, mostly chemical, which can activate cells. Early in evolution, cells developed ways to recognize crucial signals and discount disruptive signals. The cells developed systems of membranes and methods of translating information across them. Membranes give cells their individuality by separating them from their environment. As compartmentalization has evolved so has intracellular communication via intracellular messengers. Calcium has been selected as an intracellular messenger and is the messenger of interest in this dissertation.

As technological advances are made, more environmental signals are ever present. Evolution is proceeding slower than technology. For example, trace metals in the water supplies become bioconcentrated and reach levels that may be toxic to membrane proteins not yet evolved to deal with the toxic effect. Drug-induced photosensitivity is also 
becoming a health problem. Many photoactive chemicals are found in cosmetics, food additives, antibacterial agents, anti-cancer agents, industrial and agricultural products. It is important to determine how these toxic agents interact with biological membranes to produce deleterious effects. In this dissertation, the interaction between an intracellular membrane, the sarcoplasmic reticulum (SR), and environmentally toxic agents are investigated to help understand the molecular mechanism behind excitationcontraction coupling in skeletal muscle.

Before discussing the historical research directly related to the $S R$, it is important to describe membranes and calcium homeostasis in a general way. Further information can be obtained from any general biochemistry text such as found in references $1-4$.

\section{MEMBRANES}

The membrane that surrounds a living cell is much more than a simple boundary. It not only defines the outer limits of the cell but also acts to maintain a distinct environment inside and outside of the cell. The outer membrane regulates the transport of substances into and out of the cell. The internal membranes, which enclose the nucleus and other organelles, such as microsomes, endoplasmic (sarcoplasmic) reticulum and mitochondria, play 
an equally important role. The composition of the membranes make them suited to accomplish their functions.

The plasma membrane (outer) and internal membranes have many common features. They are both composed of proteins and lipids. In mammalian cells, carbohydrates can also be associated with either proteins (glycoproteins), or the lipids (glycolipids). Lipids make up the structural matrix of the membrane. While membrane-bound proteins can contribute to the structural integrity of the membrane, their primary function is to act as enzymes, pumps or ionic channels. Variation in the protein and lipid compositon of the membrane help define its distinctive characteristics.

Individual phospholipid molecules contain a polar head and hydrophobic tails. The head and tails are joined by a glycerol group. The tails consist of long chains of fatty acids which are hydrophobic and as such will orient away from water. The hydrophilic heads are more soluble in water. Molecules of this kind, with hydrophilic and hydrophobic ends are called amphipatic. It is this characteristic which helps determine the arrangements of the lipids in the membrane. They form a bilayer; i.e., two layers form back to back. The bilayer of most biological membranes is about 45 Angstroms thick. It is this bilayer framework of the membrane which anchors the proteins.

Membrane proteins can be divided into two distinct types according to orientation in the membrane lipid 
framework. One class of proteins, extrinsic membrane proteins, are only associated with the membrane surface. They can be adjacent to either the outer or inner surface of the membrane. These proteins can usually be dissociated from the membranes by either high salt concentrations or by chaotropic agents. A second class of proteins actually penetrate into the lipid bilayer and are called intrinsic membrane proteins. The intrinsic proteins are more difficult to dissociate from the membranes, however, they may be extracted by treating the membranes with detergents such as sodium dodecyl sulfate or by the addition of organic solvents (5).

In a similar fashion to the phospholipids, proteins are amphipathic. They contain a hydrophilic part which predominantly faces the aqueous phase, and a hydrophobic region which is buried in the membrane and is usually associated with the fatty acid tails of the phospholipids. The region exposed to water is made up of primarily hydrophilic amino acids (cysteine, lysine, histidine, arginine, aspartic acid, glutamic acid, serine and threonine), while the part embedded inside the lipid bilayer contains predominantly hydrophobic amino acids (alanine, leucine, isoleucine, valine, proline, phenylalanine, tryptophan and methionine). The more deeply the protein is embedded in the membrane the less surface of the protein is exposed to the aqueous surroundings. 
The most popular model of membrane structure is the fluid mosaic model proposed by S.J. Singer and G.L. Nicolson in 1972 (6) and expanded by Capaldi in 1974 (5) (see Figure 1). Their model provides for widely different protein content, for asymmetry, and can be used to explain the electrical properties and permeability of membranes (6). In this model, the individual lipids can move laterally giving the membrane its fluidity and the proteins are either associated with or embedded within the bilayer forming a mosaic-like structure on the lipid bilayer. The proteins are not static but are free to diffuse laterally in two dimensions. Transverse diffusion of proteins is not favored thermodynamically, therefore the membrane does show sidedness $(5,6)$.

Distinct functions of the membrane such as ion transport and energy transduction are the responsibility of specific proteins. Transmembrane (intrinsic) proteins serve as ionic channels, and gating probably involves major tertiary and quaternary conformational changes of the channel protein. The channels may be gated by electrical or chemical messengers. When errant signals are received, the results are often serious. Major diseases, such as cholera and whooping cough, are caused by a toxin produced by the invading organism (7). The toxin reacts at a biochemical level to interfere with cellular communication. 


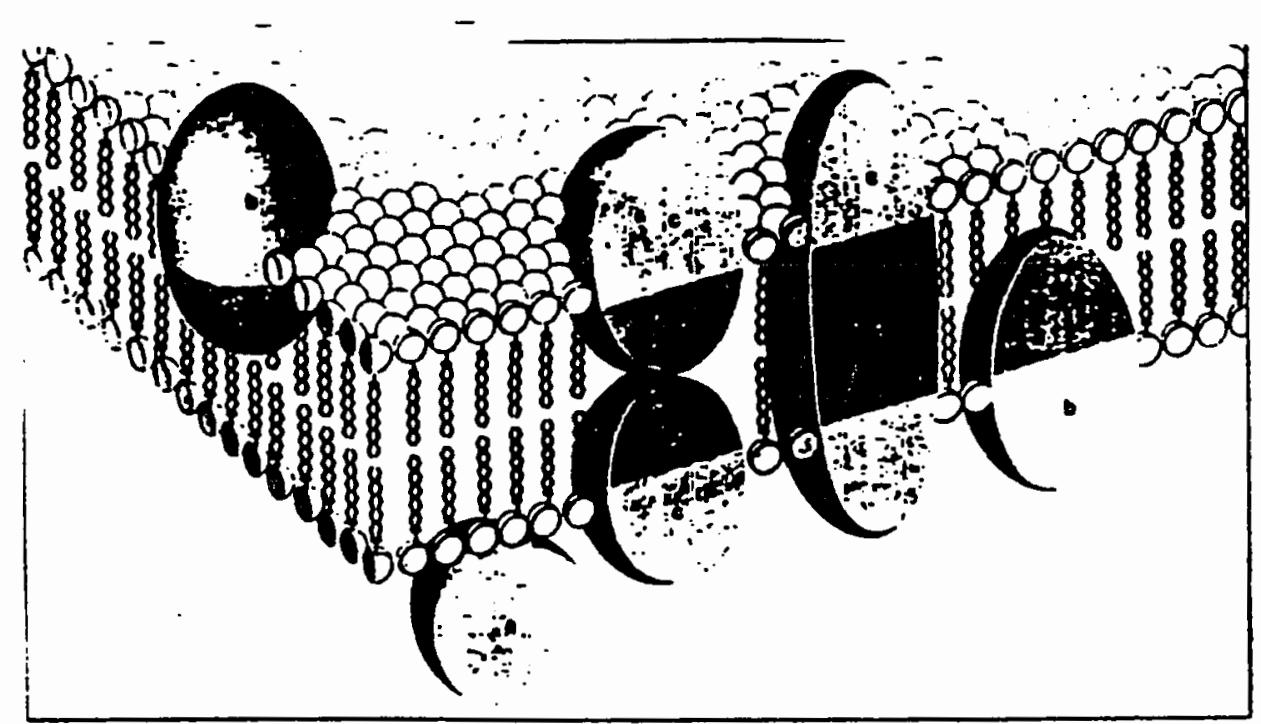

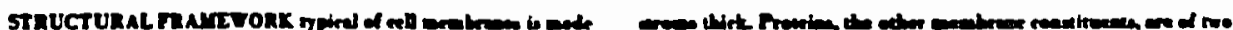

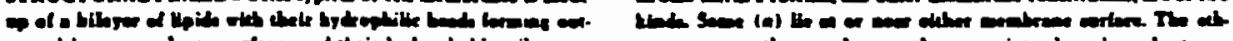

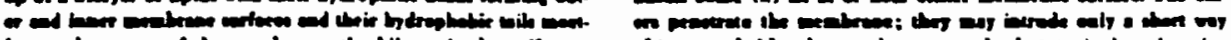

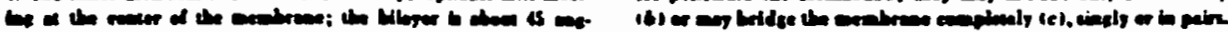

Figure 1. A diagran of the fluid mosaic membrane model. This diagram was adapted from reference 5 . 
CALCIUM AS AN INTRACELLULAR MESSENGER

Any chemical designed to function as an intracellular messenger may undergo large fluctuations in concentration. It is evident that significant concentration swings can only be achieved rapidly if the chemical in question is designed to perform the signaling function in a very low concentration range. $\mathrm{Ca}^{2+}$ is one such important chemical messenger in biological systems. $\mathrm{Ca}^{2+}$ was probably selected as a messenger over monovalent ions or other divalent ions because of its size and charge density (8). since control of $\mathrm{Ca}^{2+}$ concentration is not possible by metabolic synthesis and degradation, other mechanisms have evolved. Cells regulate their calcium concentration by reversibly complexing $\mathrm{Ca}^{2+}$ to specific ligands. $\mathrm{Ca}^{2+}$ may have been chosen over $\mathrm{Mg}^{2+}$ due to its larger radius and flexible coordination number of 6-8. These features may apply less physical constraints on the ligating protein with its irregular cavities or varying distances to coordinating oxygen atoms (8).

The evidence for the role of $\mathrm{Ca}^{2+}$ as a trigger for cell movement, cell division, secretion and other types of cell activity has been based on direct measurements of free $\mathrm{Ca}^{2+}$ in the cells and indirect evidence such as $\mathrm{Ca}^{2+}$ fluxes induced by $\mathrm{Ca}^{2+}$ ionophores (9). It is important to determine how $\mathrm{Ca}^{2+}$ operates and how it is mobilized; i.e. how it is released from subcellular $\mathrm{Ca}^{2+}$ storage 
compartments such as the sarcoplasmic reticulum and transported through ion channels.

The calcium ion serves as a chemical messenger in different ways $(8-9):$ 1) gated $\mathrm{Ca}^{2+}$ channels deliver messenger ions rapidly into the cytoplasm across the plasma membrane or an internal membrane (e.g., the vision cascade), 2) $\mathrm{Ca}^{2+}$ pumps sequester free calcium ions to limit signal duration (e.g., the $\mathrm{Ca}^{2+}, \mathrm{Mg}^{2+}$-ATPase of muscles), and 3) regulatory molecules, such as calmodulin, are turned on or off by varying concentrations of $\mathrm{Ca}^{2+}$. Intracellular $\mathrm{Ca}^{2+}$ performs the function of carrying signals to a large number of biochemical activities in the subcellular compartments. The very high extracellular $\mathrm{Ca}^{2+}$ concentration (in the $\mathrm{mM}$ range) as compared to the very low intracellular $\mathrm{Ca}^{2+}$ concentration (sub $\mu \mathrm{M}$ ) is particularly useful to its role as an intracellular regulator. Very small changes in the membrane permeability produces large fluxes of $\mathrm{Ca}^{2+}$, thereby significantly changing the intracellular $\mathrm{Ca}^{2+}$ concentration. These changes in intracellular $\mathrm{Ca}^{2+}$ then affect cellular function.

\section{CALCIUM ATPaSE IN MEMBRANES}

Eukaryotic cells contain $\mathrm{Ca}^{2+}$ transporting systems in the plasma membrane, in mitochondria and in the endoplasmic/sarcoplasmic reticulum $(10,11)$. There are at least two distinctive types of $\mathrm{Ca}^{2+}$ transporting systems: 
1.) low-affinity exchangers and gated channels which transport bulk amounts of $\mathrm{Ca}^{2+}$ and, 2.) high- affinity $\mathrm{Ca}^{2+}, \mathrm{Mg}^{2+}$-ATPases which couple the energy- producing hydrolysis of ATP to the translocation of $\mathrm{Ca}^{2+}$ across a membrane against a large $\mathrm{Ca}^{2+}$ gradient.

The $\mathrm{Ca}^{2+}$ pump on the endoplasmic reticulum has a molecular weight of approximately 100,000. It is an intrinsic membrane protein representing between $50-80 \%$ of the protein content of the endoplasmic reticulum $(10,11$, 12). The sarcoplasmic reticulum (SR) in skeletal muscle is a specialized endoplasmic reticulum which has been adapted to control the $\mathrm{Ca}^{2+}$ concentration in muscle cells. The pump, $\mathrm{Ca}^{2+}, \mathrm{Mg}^{2+}-\mathrm{ATPase}$, is capable of lowering the free cytosolic $\mathrm{Ca}^{2+}$ concentration to less than $100 \mathrm{nM} \mathrm{(13)} \mathrm{and}$ can establish a 1000 or greater fold gradient.

The density of the pump in the SR is approximately $20,000 / \mu^{2}$. It accounts for approximately $70-80 \%$ of the membrane protein (13). The SR contains two distinct regions: the heavy or terminal cisternae region and the light or longitudinal region (14-17). The heavy sarcoplasmic reticulum (HSR) contains a high density of the $\mathrm{Ca}^{2+}$ binding protein, calsequestrin (18). Calsequestrin acts as a $\mathrm{Ca}^{2+}$ storage site in the HSR (18). The light sarcoplasmic reticulum (LSR) contains no calsequestrin. The ISR and HSR can be separated by sucrose-gradient centrifugation (19-22). These two membrane components 
differ in protein composition and $\mathrm{Ca}^{2+}$ transport activity $(21,22,23)$ (see Figure 2).

While the ATPase has been extensively characterized $(13,24)$, the mechanism by which $\mathrm{Ca}^{2+}$ is rapidly released from the SR is less well defined. Muscle contraction is initiated by depolarization of the sarcolemma which subsequently results in the depolarization of the transverse tubule $(17,25,26)$. The depolarization of the T-tubules somehow triggers a series of events resulting in the rapid release of $\mathrm{Ca}^{2+}$ from the $\mathrm{SR}(27,28)$. As a result of $\mathrm{Ca}^{2+}$ release from the $\mathrm{SR}$, the myoplasmic $\mathrm{Ca}^{2+}$ concentration increases to greater than $10^{-6} \mathrm{M}$ (29-34). The cytoplasmic $\mathrm{Ca}^{2+}$ then binds to troponin which results in a change in the filament structure, thereby facilitating the interaction of myosin with actin, with the subsequent cleavage of ATP and the development of a contraction $(35-37)$.

\section{CALCIUM RELEASE}

Currently, most theories recognize that depolarization of the $\mathrm{T}$-tubule is coupled to $\mathrm{Ca}^{2+}$ release from skeletal muscle SR. Schneider-Chandler $(28,38)$ proposed a model coupling depolarization of the $\mathrm{T}$-tubule to opening of $\mathrm{Ca}^{2+}$ channels in the junctional region of the SR. Since a large $\mathrm{Ca}^{2+}$ gradient, generated by the $\mathrm{Ca}^{2+}$ pump, exists across the SR in the resting muscle, the opening of $\mathrm{Ca}^{2+}$ channels results in the rapid release of stored $\mathrm{Ca}^{2+}$ from 

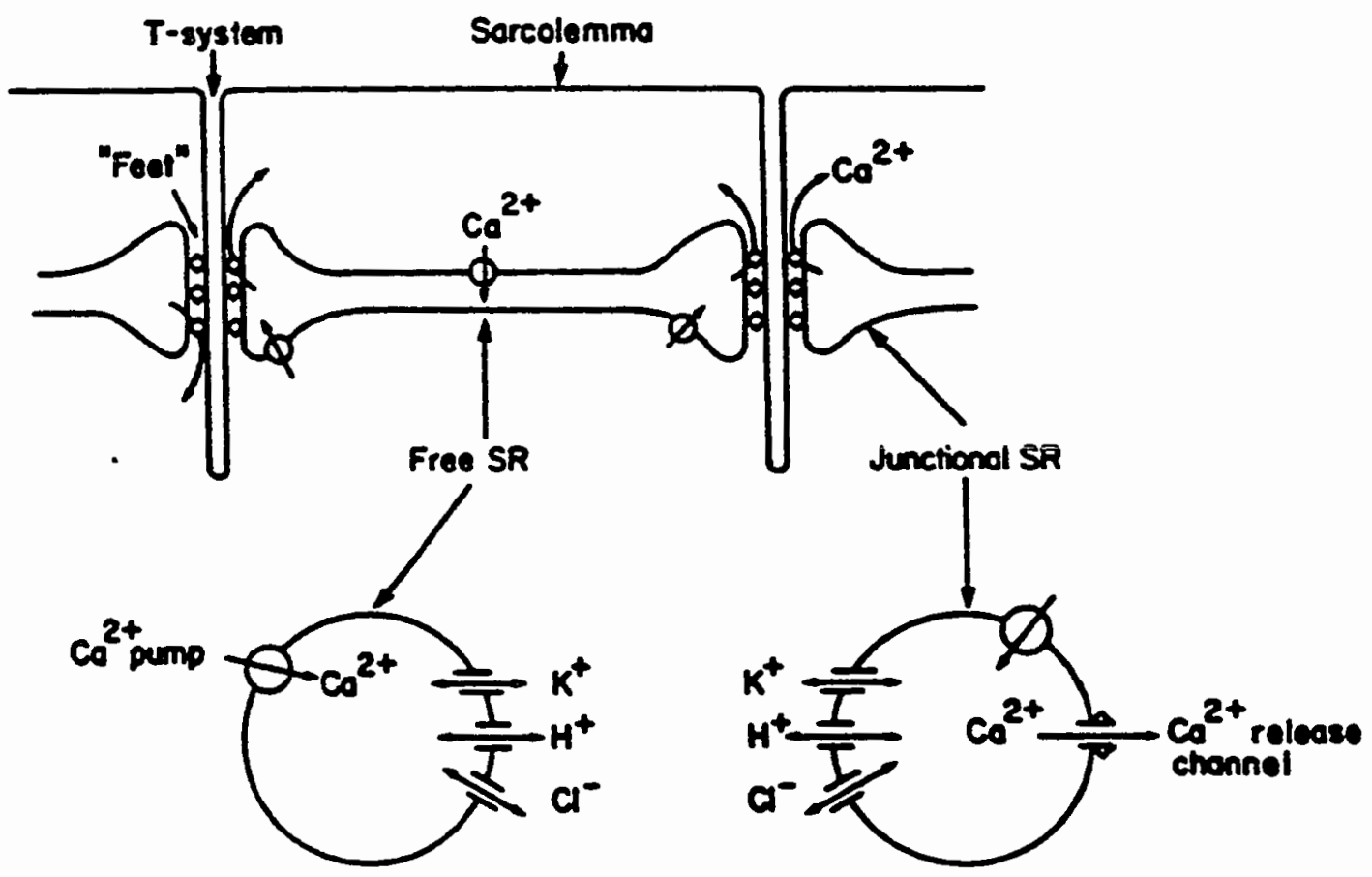

"LIGHT" SR VESICLES "HEAVY" SR VEsicles

Figure 2. Schematic representation of sarcoplasmic reticulum. This drawing is adapted from reference 23 . 
the SR. The coupling of charge movement to $\mathrm{Ca}^{2+}$ release is complex and is proposed to involve electrical and mechanical intermediates $(39,40)$. The second, and currently more popular model among biochemists, is that of chemical signaling $(41-44)$. This model proposes that $\mathrm{Ca}^{2+}$ release is triggered either directly or indirectly by chemical modification of the SR. The $\mathrm{Ca}^{2+}$ content of the SR reflects an equilibrium between active uptake of $\mathrm{Ca}^{2+}$ by the pump, the binding of $\mathrm{Ca}^{2+}$ to components of the SR and the release of $\mathrm{Ca}^{2+}$ from the SR. The mechanism of the pump has been briefly discussed; more information can be found in references $(12,13)$. Further discussion will focus on the $\mathrm{Ca}^{2+}$ release system of skeletal muscle sarcoplasmic reticulum.

Before 1980 a limited amount of work had been done on $\mathrm{Ca}^{2+}$ release from $\mathrm{SR}$. Most of these studies involved examining "leakiness" of $S R$ vesicles rather than the specific triggering of the $\mathrm{Ca}^{2+}$ release system. For a complete review of these works see reference (10).

\section{Calcium-induced calcium release}

Nevertheless, in the 1960's some farsighted hypotheses were proposed. Bianchi and Bolton (45-46) first suggested the mechanism of $\mathrm{Ca}^{2+}$-induced $\mathrm{Ca}^{2+}$ release. Endo (47) and Ford and Podolsky (48) independently provided the first experimental support for this proposed mechanism. since then $\mathrm{Ca}^{2+}$-induced $\mathrm{Ca}^{2+}$ release has been extensively studied 
in skinned skeletal $(44,49-50)$ and cardiac fibers $(34,37$, $42-43,51-52)$ and in SR vesicles (53-60). Still, no clear evidence has appeared to indicate a physiological relevance of $\mathrm{Ca}^{2+}$-induced $\mathrm{Ca}^{2+}$ release (61). $\mathrm{Ca}^{2+}$-induced $\mathrm{Ca}^{2+}$ release is influenced by the extravesicular $\mathrm{Ca}^{2+}$ concentration (49, 57-58), the $\mathrm{Ca}^{2+}$ gradient (58-59), adenine nucleotides $(57,59-60)$, magnesium $(44,49,55,59$, 62-63), caffeine, (49, 57, 59-60, 62, 64-65), local anesthetics $(49,58,59,63,66-67)$, and the cationic dye, ruthenium red $(53,55)$.

It has been suggested that the $\mathrm{Ca}^{2+}$ release channels are activated by adenine nucleotides (68-72) and opened by the binding of $\mathrm{Ca}^{2+}$. Upon opening, the internal $\mathrm{Ca}^{2+}$ exits at a rate determined by the $\mathrm{Ca}^{2+}$ gradient (58). The ATP binding site responsible for stimulating $\mathrm{Ca}^{2+}$ release has a $\mathrm{K}_{\mathrm{d}} \sim 0.1 \mathrm{mM}(68)$. This site appears to be distinct from the high-affinity $\left(\mathrm{K}_{\mathrm{d}}-2-3 \mu \mathrm{M}\right)$ or low-affinity $\left(\mathrm{K}_{\mathrm{d}}-500\right.$

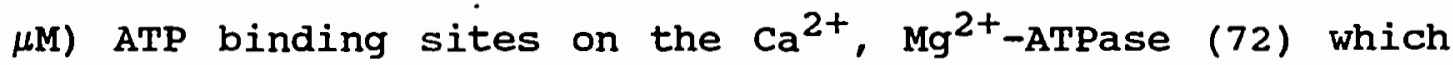
are involved in activating the $\mathrm{Ca}^{2+}$ accumulation into the SR.

$\mathrm{Mg}^{2+}$ apparently acts as a competitive inhibitor for $\mathrm{Ca}^{2+}$ by binding to the $\mathrm{Ca}^{2+}$ binding site $(49,62)$ with a $\mathrm{K}_{\mathrm{I}}$ $=100 \mu \mathrm{M}$. This suggests the $\mathrm{Mg}^{2+}$ decrease the affinity of the $\mathrm{Ca}^{2+}$ binding sites for $\mathrm{Ca}^{2+}$, thereby increasing the concentration of $\mathrm{Ca}^{2+}$ needed to induce $\mathrm{Ca}^{2+}$ release from the SR (49). Ogawa suggests that caffeine changes the 
affinity of the SR for $\mathrm{Mg}^{2+}(63-64)$. Caffeine also increase the affinity of the $\mathrm{Ca}^{2+}$ binding site for $\mathrm{Ca}^{2+}$ by 14-fold (63).

Calcium release induced by amino acid modifying reagents

Martonosi et al. (77) observed that the addition of micromolar concentrations of salyrgan induced rapid release of accumulated $\mathrm{Ca}^{2+}$ from SR vesicles. Similar effects were observed with N-ethylmaleimide (77) and pchloromercuribenzene sulfonate (pCMBS) (78). In 1983, our laboratory reported that various heavy metal ions increased the permeability of $S R$ vesicles (79). Chiu et al. (80) also reported modification by metal ions of active and passive $\mathrm{Ca}^{2+}$ transport across the $\mathrm{SR}$ membrane. Subsequently, Trimm et al. (22) showed that the addition of cysteine and copper to $S R$ vesicles induced a rapid release of the internal $\mathrm{Ca}^{2+}$. This is a result of covalent attachment of exogenous cysteine to an endogenous reactive thiol via an oxidation reaction catalyzed by copper. stuart et al. subsequently showed that oxidation-induced $\mathrm{Ca}^{2+}$ release is stimulated in the presence of adenine nucleotides (81). Phthalocyanine dyes (82) and anthraquinones (83) have also been shown to induce rapid $\mathrm{Ca}^{2+}$ release from $\mathrm{SR}$ vesicles. The reaction site of these compounds is presumed to be the same reactive thiol modified by the addition of $\mathrm{Cu}^{2+}$ and cysteine (22). Doxorubicin, a potent antineoplastic anthraquinone (84), 
can be covalently attached to several SR proteins in the presence of ultraviolet irradiation (85). Doxorubicininduced $\mathrm{Ca}^{2+}$ release is ATP dependent; however, it is inhibited in the presence of caffeine (83).

Modification of $S R$ vesicles with reagents specific for free amino groups increase the permeability of the SR to $\mathrm{Ca}^{2+}$ (86). Tenu et al. (87) have reported that the modification of 1 mole lysine and 2 mole histidine per $10^{5}$ $g$ of $S R$ protein uncoupled the translocation of $\mathrm{Ca}^{2+}$ from the hydolysis of ATP. Yu (88), Martonosi (89) and Kondo and Kasai et al. (90) also reported that the destruction of histidyl residues in SR decreases the translocation of $\mathrm{Ca}^{2+}$ by the ATPase followed by a slower disruption of the hydrolysis of ATP.

Isolation of SR proteins involved in $\mathrm{Ca}^{2+}$ release

To totally characterize a protein requires working with an isolated protein. SR vesicles can be isolated into distinct populations which are biochemically and structurally distinct (68). The terminal cisternae, the part of the SR which lies in close proximity to the transverse tubule in vivo, contains the $\mathrm{Ca}^{2+}$ release protein, calsequestrin (a $\mathrm{Ca}^{2+}$ binding protein), and other minor components as well as the $\mathrm{Ca}^{2+}, \mathrm{Mg}^{2+}$-ATPase. The primary protein component of the longitudinal SR is the $\mathrm{Ca}^{2+}, \mathrm{Mg}^{2+}$-ATPase. The longitudinal $\mathrm{SR}$ is noticeably void of $\mathrm{Ca}^{2+}$ release protein and calsequestrin. Electron 
micrographs have shown that the transverse tubule and the terminal cisternae are structurally connected by a spanning protein and this protein is retained in $S R$ vesicles isolated from the terminal cisternae (HSR) (91-92).

Ryanodine, a neutral plant alkaloid, has been shown to either increase or decrease the $\mathrm{Ca}^{2+}$ permeability of HSR depending upon the reaction conditions. At concentrations less than $10 \mu \mathrm{M}$, ryanodine increased $\mathrm{Ca}^{2+}$ efflux while at concentrations greater than $10 \mu \mathrm{M}$ the $\mathrm{Ca}^{2+}$ efflux decreased (94). The high affinity binding site has a $K_{d} \sim 2-10 \mathrm{nM}$ (94). The addition of $1 \mathrm{mM} \mathrm{Mg}^{2+}$ increases the $\mathrm{K}_{\mathrm{d}}$ from $\sim 2$ nM to $4.5 \mathrm{nM}$. Stimulators of $\mathrm{Ca}^{2+}$ release such as ATP, caffeine (94-95) and doxorubicin (83) stimulate ryanodine binding. Silver and reactive disulfides rapidly displace bound ryanodine (94) .

on the basis of ryanodine binding, a $~ 400 \mathrm{~K}$ dalton protein has been isolated (96-97), which when incorporated into a black lipid membrane shows $\mathrm{Ca}^{2+}$ conductance that is inhibited by ruthenium red. This isolated protein shows a $\mathrm{K}_{\mathrm{d}} \sim 10 \mathrm{nM}$ and $\mathrm{a} \mathrm{B}_{\max } \sim 540 \mathrm{pmole} / \mathrm{mg}$ which corresponds to 1 mole ryanodine bound per four $400 \mathrm{~K}$ dalton proteins. Electron microscopy has shown that the $400 \mathrm{~K}$ dalton protein forms a tetrameric complex, which corresponds to the previously isolated junctional membrane foot structure (96). On the basis of these findings it has been proposed that the $400 \mathrm{~K}$ dalton protein acts as both the $\mathrm{Ca}^{2+}$ release 
protein and the foot structure which bridges the gap between the T-tubule and the terminal cisternae of the SR.

\section{OVERVIEW OF THIS DISSERTATION}

In this dissertation, the interaction between an intracellular membrane, the sarcoplasmic reticulum (SR), and environmentally toxic agents is used to help understand the molecular mechanism behind excitation-contraction coupling in skeletal muscle. The SR plays a critical role in the muscle contraction/relaxation cycle. When the myoplasmic $\mathrm{Ca}^{2+}$ concentration exceeds a few micromolar muscles contract and when the myoplasmic $\mathrm{Ca}^{2+}$ concentration is lowered into the submicromolar range muscles relax. The major role or function of the $S R$ is to regulate the myoplasmic $\mathrm{Ca}^{2+}$ concentration. $\mathrm{Ca}^{2+}$ is transported into the SR from the myoplasm via a $\mathrm{Ca}^{2+}, \mathrm{Mg}^{2+}$-ATPase, thus lowering the myoplasmic $\mathrm{Ca}^{2+}$ concentration. $\mathrm{Ca}^{2+}$ exits from the $\mathrm{SR}$ via a $\mathrm{Ca}^{2+}$ release pathway resulting in the increase of myoplasmic $\mathrm{Ca}^{2+}$. The $\mathrm{Ca}^{2+}, \mathrm{Mg}^{2+}-\mathrm{ATPase}$ has been extensively studied, but the $\mathrm{Ca}^{2+}$ release system is less well understood. The main focus of this dissertation is to study the $\mathrm{Ca}^{2+}$ release pathway in isolated $\mathrm{SR}$ vesicles.

Skeletal muscle SR vesicles are isolated from the fast twitch muscles of rabbit. Isolation of $S R$ vesicles does remove the SR membrane system from its biomechanical 
constraints, however, it is believed that the SR vesicles provide an acceptable model for the studies performed here. SR vesicles are further fractionated into heavy SR (HSR) and light SR (LSR) using a sucrose gradient. Both fractions of the SR contain $\mathrm{Ca}^{2+}, \mathrm{Mg}^{2+}$-ATPases and $\mathrm{K}^{+}, \mathrm{Cl}^{-}$, and possibly $\mathrm{H}^{+}$ion channels. In addition, the HSR contains the $\mathrm{Ca}^{2+}$ release protein.

It is shown in chapter III of this dissertation that oxidation-induced $\mathrm{Ca}^{2+}$ release is stimulated by adenine nucleotides with an order of effectiveness of:

$$
\text { ATP > AMP-PCP > CAMP > AMP > adenine }
$$

The stimulatory effect has an absolute requirement for the adenine moiety but does not require the phosphorylation of a protein. AMP-PCP, a non-hydrolyzable analogue of ATP, is almost as effective as ATP in stimulating $\mathrm{Ca}^{2+}$ release. oxidation-induced $\mathrm{Ca}^{2+}$ efflux is affected by the same modulators as $\mathrm{Ca}^{2+}$-induced $\mathrm{Ca}^{2+}$ efflux. This indicates that the two methods of stimulating $\mathrm{Ca}^{2+}$ release from the SR are probably operating on the same protein.

oxidation-induced $\mathrm{Ca}^{2+}$ release exhibits an unusual $\mathrm{pH}$ dependence (22). The $\mathrm{pH}$ optimum is 7.0 and the efflux rates are slower at $\mathrm{pH}$ below or above 7.0. The $\mathrm{pk}_{\mathrm{a}}$ of amino acids can be altered by the mircoenvironment in which they reside. Histidines are known to hydrogen bond to cysteines in soluble enzymes and histidines are also found in ATP binding sites. It was of interest to determine if 
the modification of histidyl residues would alter the $\mathrm{Ca}^{2+}$ permeability of the SR vesicles.

Photooxidation of SR vesicles, using rose bengal or methylene blue as the sensitizer, results in the increased $\mathrm{Ca}^{2+}$ permeability of the vesicles. It is shown in chapter IV of this dissertation that photooxidation-induced $\mathrm{Ca}^{2+}$ release reacts differently to known modulators of $\mathrm{Ca}^{2+}$ release than does either $\mathrm{Ca}^{2+}$-induced or oxidation-induced $\mathrm{Ca}^{2+}$ efflux. Photooxidation-induced $\mathrm{Ca}^{2+}$ release is inhibited by adenine nucleotides and the maximal efflux rates are $\mathrm{Mg}^{2+}$ independent. The photooxidation target is a ruthenium red insensitive protein in the SR indicating that this effect is likely to be on some protein other than the $\mathrm{Ca}^{2+}$ release protein.

Covalent modification of histidyl residues with ethoxyformic anhydride (EFA) also results in an increase in the $\mathrm{Ca}^{2+}$ permeability of $\mathrm{SR}$ vesicles. Similar to photooxidation-induced $\mathrm{Ca}^{2+}$ efflux, EFA-induced $\mathrm{Ca}^{2+}$ efflux is inhibited by adenine nucleotides and the maximal $\mathrm{Ca}^{2+}$ efflux rates are $\mathrm{Mg}^{2+}$ independent. Nevertheless, there is a delay in the initiation of $\mathrm{Ca}^{2+}$ efflux after the addition of EFA when the experiments are performed at high $\mathrm{Mg}^{2+}$. Thus $\mathrm{Mg}^{2+}$ somehow provides some protection to modification of histidyl residues or interferes with the reaction mechanism thereby resulting in a delay in the initiation of 
$\mathrm{Ca}^{2+}$ efflux. Once the SR vesicles have been modified the $\mathrm{Ca}^{2+}$ efflux rates are $\mathrm{Mg}^{2+}$ independent.

The data presented in this dissertation provide new and valuable information describing the $\mathrm{Ca}^{2+}$ release pathway of $S R$ vesicles. While histidine modification appears to be on a protein other than the $\mathrm{Ca}^{2+}$ release protein, the techniques established here can be used to study SR ion channels and their arrangement in the membrane. 
GHAPTER II

EXPERIMENTAL METHODS AND MATERIALS

PROTEIN PREPARATION

\section{Protein Isolation}

Sarcoplasmic reticulum vesicles were prepared from white skeletal muscle of a rabbit hind leg according to a modification of the method described by MacLennan (98). The rabbit was anesthetized with pentobarbital, bled by cutting the jugular vein, and the muscles from the back and hind legs removed. The muscle was trimmed of fat and connective tissue, ground through a meat grinder, then mixed in a $1: 4$ ratio with a $0.12 \mathrm{M} \mathrm{NaCl,} 0.01 \mathrm{M}$ Imidazole, pH 7.4, $100 \mu \mathrm{M}$ dithiothreitol (DTT) buffer. The suspension was homogenized for 15 seconds on low, then 30 seconds on high speed in a waring blender. The suspension was then centrifuged at $1600 \mathrm{~g}$ for $10 \mathrm{minutes.} \mathrm{The} \mathrm{supernatant} \mathrm{was}$ separated, strained through cheesecloth, the $\mathrm{pH}$ adjusted to 7.4 with dry imidazole and centrifuged for 15 minutes at $10,000 \mathrm{~g}$. The brown mitochondrial pellet was discarded and the supernatant was again filtered through cheesecloth and centrifuged at $44,000 \mathrm{~g}$ for 70 minutes. The supernatant was pipetted off, discarded and the pellet was scraped off the bottom of the tube (avoiding the brown mitochondrial 
ring). The protein was homogenized and suspended at approximately $10 \mathrm{mg} / \mathrm{ml}$ in the same buffer without DTT. The homogenate was centrifuged for 10 minutes at 75,000 $\mathrm{g}$. The supernatant was very carefully removed to avoid disturbing the large flocculent myosin pellet and then was centrifuged for 30 minutes at $78,000 \mathrm{~g}$. The pellet which contained the preparation of $S R$ vesicles was homogenized and resuspended at about $25 \mathrm{mg} / \mathrm{mL}$ in $100 \mathrm{mM} \mathrm{KCl}, 50 \mathrm{mM}$ Hepes$\mathrm{KOH} \mathrm{pH}$ 7.0. The $\mathrm{SR}$ was frozen in liquid nitrogen until needed. The whole procedure was conducted in the cold room and the centrifugations were carried out at $0^{0} \mathrm{c}$.

\section{Preparation of Light and Heavy SR Vesicles}

SR vesicles prepared as described above were further fractionated on a $30-45 \%(\mathrm{w} / \mathrm{w})$ discontinuous sucrose gradient. A $45 \%(\mathrm{w} / \mathrm{w})$ sucrose stock solution was prepared by combining $450 \mathrm{~g}$ ultrapure sucrose with $550 \mathrm{~g} 100 \mathrm{mM} \mathrm{KCl}$, $50 \mathrm{mM}$ Hepes-KOH (KCl-Hepes) buffer, $\mathrm{pH}$ 7.0. The sucrose solution was run through an ion-exchange column to remove any trace metal contamination. The column was prepared from Bio-Rad Chelex-100 (50-100 mesh) resuspended in $\mathrm{KCl}-$ Hepes buffer, $\mathrm{pH}$ 7.0. The column was washed until the eluate was $\mathrm{pH} 7.0$. The sucrose solution was slowly poured onto the column, the beads allowed to settle, and the first $50 \mathrm{~mL}$ discarded. The remaining heavy-metal-free sucrose solution was collected in a beaker rinsed thoroughly with EGTA followed by 10 double distilled water rinses. Using 
the density of sucrose solutions (CRC Handbook of Chemistry and Physics) as a guide, the stock sucrose solution was diluted with $\mathrm{KCl}$-Hepes buffer, $\mathrm{pH} 7.0$ to the following percentages:

$\begin{array}{llr}40 \% & \text { Sucrose }(90 \mathrm{~mL}): & 79 \mathrm{~mL} 45 \% \text { sucrose }+11 \mathrm{~mL} \text { buffer } \\ 36 \% \text { Sucrose }(140 \mathrm{~mL}): & 108 \mathrm{~mL} 45 \% \text { sucrose }+32 \mathrm{~mL} \text { buffer } \\ 32 \% \text { Sucrose }(90 \mathrm{~mL}): & 60 \mathrm{~mL} 45 \% \text { sucrose }+30 \mathrm{~mL} \text { buffer } \\ 30 \% \text { Sucrose }(50 \mathrm{~mL}): & 31 \mathrm{~mL} 45 \% \text { sucrose }+19 \mathrm{~mL} \text { buffer }\end{array}$

Six sucrose gradient tubes, using disposable polyallomer tubes, were prepared in the cold room to minimize mixing of the solution as they were pipetted. The gradient was made by adding the following volumes of each of the sucrose solutions:

$$
\begin{array}{r}
4 \mathrm{~mL} \text { of } 45 \% \\
7 \mathrm{~mL} \text { of } 40 \% \\
11 \mathrm{~mL} \text { of } 36 \% \\
7 \mathrm{~mL} \text { of } 32 \% \\
4 \mathrm{~mL} \text { of } 30 \%
\end{array}
$$

A normal unfractionated SR preparation yields 500-600 $\mathrm{mg}$ of protein. Approximately $300 \mathrm{mg}$ of the crude SR was further fractionated into heavy (HSR) and light SR (LSR). Approximately $2 \mathrm{~mL}$ of the unfractionated $\mathrm{SR}$ at $25 \mathrm{mg} / \mathrm{mL}$ was layered unto the top of each of six gradient tubes. The tubes were placed into the buckets of a Beckman SW28 swinging-bucket rotor, opposite buckets were balanced and then hung on the rotor head. The SR/sucrose gradient was centrifuged at 22,000 RPM for 15-18 hours.

The centrifuge was allowed to stop without using the brake in order to avoid mixing of the gradients. Two distinct bands were usually present. ISR vesicles 
equilibrated at the $32-36 \%$ interface while HSR vesicles were found at the $36-40 \%$ interface. The protein bands were withdrawn with a $10 \mathrm{~mL}$ syringe fitted with an 18-gauge needle. The protein/sucrose samples were diluted 2-3x with $\mathrm{KCl}$-Hepes buffer, $\mathrm{pH} 7.0$ and centrifuged at 45,000 RPM for 30 minutes. The pellets were resuspended in the same buffer and centrifuged again at 45,000 RPM for 30 minutes. The protein was then homogenized and suspended at a concentration of approximately $15 \mathrm{mg} / \mathrm{mL}$ in $\mathrm{KCl}$-Hepes buffer, $\mathrm{pH}$ 7.0. The protein was stored as $100 \mathrm{uL}$ samples in liquid nitrogen until needed.

\section{Protein Concentration Determination}

Protein concentration was determined by absorption spectroscopy (99). The protein was diluted 1:100 in 1\% sodium dodecyl sulfate and the absorbance at 280 and $260 \mathrm{~nm}$ was determined. The protein concentration was then calculated by the following formula:

eq 1: Protein $(\mathrm{mg} / \mathrm{mL})=1.45 \mathrm{Abs}_{280}-0.74 \mathrm{Abs}_{260}$

The protein concentration determined by the above equation was multiplied by 100 to compensate for a 100 fold dilution into the spectrophotometer. 
MEASUREMENT OF $\mathrm{Ca}^{2+}$ EFFIUX

$\mathrm{Ca}^{2+}$ fluxes were measured by three different methods: 1) spectrophotometrically using a $\mathrm{Ca}^{2+}$-sensitive dye, arsenazo III (AsIII) or antipyrylazo III (APIII); 2) using a $\mathrm{Ca}^{2+}$-selective electrode (WPI-Cal-1-electrode); and 3) by ${ }^{45} \mathrm{Ca}^{2+}$ retention on Millipore filters. Extravesicular $\mathrm{Ca}^{2+}$, using AsIII (APIII) as an indicator, was measured using a dual wavelength spectrophotometer (100) by monitoring the differential absorption changes at 675-685 $\mathrm{nm}$ (for AsIII) or 710-790 $\mathrm{nm}$ (for APIII). For active experiments, $\mathrm{SR}$ vesicles $(0.2 \mathrm{mg} / \mathrm{mL}$ unless otherwise noted)

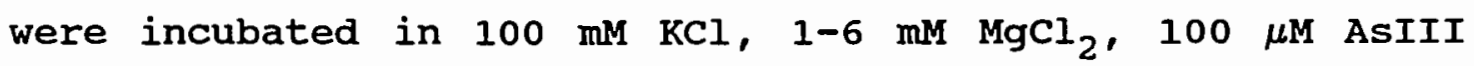
(APIII), $50 \mathrm{mM}$ Hepes-KOH, $\mathrm{pH} \mathrm{6.8-7.0.} \mathrm{Two} \mathrm{aliquots} \mathrm{of} \mathrm{Ca}^{2+}$ (10 $\mu \mathrm{M}$ each) were added to calibrate the AsIII (APIII)-Ca ${ }^{2+}$ signal. Uptake was initiated by the addition of either acetyl phosphate $\left(\mathrm{ACPO}_{4}\right)$ or $\mathrm{Mg}^{2+}$-ATP. Release was initiated by the addition of the effluxing reagent. After efflux had stopped, as indicated by a leveling off of the AsIII (APIII) signal, A23187 ( - .2 ug/mL), a $\mathrm{Ca}^{2+}$ ionophore, was added to release any remaining $\mathrm{Ca}^{2+}$. In passive experiments, SR vesicles $(-10 \mathrm{mg} / \mathrm{mL})$ were incubated in 100 $\mathrm{mM} \mathrm{KCl}, 1-6 \mathrm{mM} \mathrm{MgCl}_{2}, 1 \mathrm{mM} \mathrm{CaCl} 2,50 \mathrm{mM}$ Hepes-KOH, $\mathrm{pH} 7.0$ overnight at $4^{\circ} \mathrm{C}$. The vesicles were then diluted $50 \mathrm{x}$ into a $\mathrm{Ca}^{2+}$-free buffer containing $100 \mu \mathrm{M}$ AsIII (APIII). Efflux was initiated by addition of the appropriate reagent. Approximately $1 \mu \mathrm{M} \quad \mathrm{A} 23187$ was added after efflux had 
stopped. The $\mathrm{Ca}^{2+}$-AsIII (APIII) signal was calibrated with the addition of $4-8 \mu \mathrm{M} \mathrm{Ca}^{2+}$. For slower release experiments, $S R$ was diluted into a buffer containing releasing reagent, then after a specified time (usually several minutes with or without illumination) $100 \mu \mathrm{M}$ AsIII (APIII) was added to establish an absorbance baseline and differential absorption was monitored at 675-685 nm (710$790 \mathrm{~nm}$ for APIII). Approximately 1-2 $\mu \mathrm{M}$ A23187 was added to release the remaining $\mathrm{Ca}^{2+}$. To determine the amount of internal $\mathrm{Ca}^{2+}$ in the untreated vesicles, 1-2 \}M A23187 was added to an untreated sample. This amount of $\mathrm{Ca}^{2+}$ was taken to represent $100 \%$ of the internal releasable $\mathrm{Ca}^{2+}$. The percent of $\mathrm{Ca}^{2+}$ remaining in the vesicles was determined by dividing the amount of $\mathrm{Ca}^{2+}$ remaining in the treated vesicles by the amount of releasable $\mathrm{Ca}^{2+}$ in the untreated vesicles. A 4-8 $\mu \mathrm{M}$ aliquot of $\mathrm{Ca}^{2+}$ was added after the release of $\mathrm{Ca}^{2+}$ by $\mathrm{A} 23187$ to calibrate the AsIII (APIII) $-\mathrm{Ca}^{2+}$ signal.

$\mathrm{Ca}^{2+}$ uptake and efflux were also monitored using a $\mathrm{Ca}^{2+}$-selective electrode (WPI-Cal-1-electrode). The electrode was calibrated and the data were digitized by a Scientific Solutions Labmaster analog to digital converter interfaced with an IBM XT computer. Voltage readings from the electrode were converted into free $\mathrm{Ca}^{2+}$ concentrations in the extravesicular space. Only active experiments could be performed using the $\mathrm{Ca}^{2+}$-selective electrode. Uptake 
was initiated by the addition of either $\mathrm{ACPO}_{4}$ or $\mathrm{Mg}^{2}$-ATP. $\mathrm{Ca}^{2+}$ uptake was determined by monitoring the decrease in extravesicular $\mathrm{Ca}^{2+}$ concentration. Release was initiated by the addition of effluxing reagent and the change in extravesicular $\mathrm{Ca}^{2+}$ concentration was recorded as a function of time. $\mathrm{Ca}^{2+}$ efflux rates were determined from the maximal slope of the extravesicular $\mathrm{Ca}^{2+}$ concentration versus time.

Active or passive experiments using ${ }^{45} \mathrm{Ca}^{2+}$ were performed using Millipore filtration techniques coupled with rapid filtration or reaction quenching techniques. The amount of ${ }^{45} \mathrm{Ca}^{2+}$ remaining in the vesicles after reaction with a releasing reagent for a specific time was determined by measuring the amount of radioactivity remaining on a filter. Vesicles loaded with ${ }^{45} \mathrm{Ca}^{2+}$ were placed on Millipore filters $(0.45 \mu \mathrm{m}$ for quench experiments, $0.65 \mu \mathrm{m}$ for rapid filtration), washed, subjected to releasing reagent (for rapid filtration experiments only), vacuum filtered, and the remaining radioactivity counted using a solvent-free liquid scintillation fluid (Isolab, Inc.).

For some active experiments two different ATP regenerative systems were used: 1) a phosphoenolpyruvate (PEP)/pyruvate kinase (PK) system and 2) a phosphocreatine (PC)/creatine phosphokinase (CPK) system. The PEP/PK system consisted of $2 \mathrm{mM}$ PEP and 20 units PK in a $3 \mathrm{~mL}$ 
reaction vessel. The PC/CPK system used 5 units CPK and 3 $\mathrm{mM} \mathrm{PC}$ in a $3 \mathrm{~mL}$ reaction vessel.

The effluxing reagents used were copper, cysteine, rose bengal, or ethoxyformic anhydride (EFA). All effluxing reagents were prepared fresh before each experiment. When copper and cysteine were used, the cysteine was added first to the reaction buffer followed by the copper which was added to catalyze the oxidation reaction and initiate $\mathrm{Ca}^{2+}$ release. In some experiments rose bengal was irradiated with a 360-watt, broad-spectrum light source placed approximately $30 \mathrm{~cm}$ away from the sample. A beaker of water was placed between the light source and the sample to screen out infrared light. In semi-dark experiments using rose bengal, the room was lighted with diffuse light from the adjoining room. The rose bengal stock solution was stored in a dark bottle, and the reaction beaker was placed in a dark box.

\section{HISTIDINE MODIFICATION}

Ethoxyformic anhydride react with the imidazole ring of histidine according to the following reaction:

rx 1:
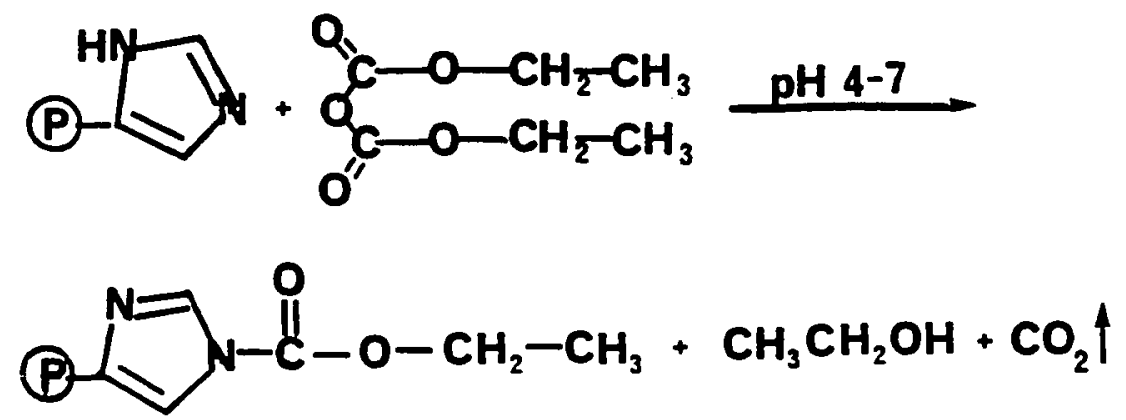
The product, N-ethoxyformylimidazole, has a characteristic spectrum with a maximum absorbance between 230 and $242 \mathrm{~nm}$ (101). The increase in the absorbance at $242 \mathrm{~nm}(\epsilon=3.2 \mathrm{x}$ $10^{3} \mathrm{M}^{-1} \mathrm{~cm}^{-1}$ [102]) was used to quantitate the extent of histidine modification. Between $0.5-0.7 \mathrm{mg} / \mathrm{mL} \mathrm{SR}$ was suspended in $100 \mathrm{mM} \mathrm{KCl}, 1-6 \mathrm{mM} \mathrm{MgCl}_{2}, 50 \mathrm{mM}$ Hepes-KOH, pH 7.0. Upon addition of EFA (various concentrations), the change in absorbance at $242 \mathrm{~nm}$ was followed as a function of time. The rate of formation of the chromophore was used to determine the kinetics of histidine modification by the following equation:

eq 2: $\frac{\text { change in } \mathrm{Abs}_{240}}{\left(3.2 \times 10^{3} \mathrm{M}^{-1}\right) \text { (change in time, seconds) }}=\mathrm{k}\left(\mathrm{M} \mathrm{sec}^{-1}\right)$

\section{ATPase ACTIVITY}

ATPase activity was determined using two coupled enzyme systems (103). The SR ATPase converted ATP to ADP, then the ADP formed was converted back into ATP in a reaction catalyzed by $\mathrm{PK}$ which converts PEP to pyruvate. The pyruvate formed was converted to lactate by the action of lactic dehydrogenase (LDH) with the subsequent oxidation of $\beta$-nicotinamide adenine dinucleotide, reduced form (NADH) . The hydrolysis of one ATP results in the oxidation of one NADH. ATPase activity was determined by monitoring 
the change in $\mathrm{Abs}_{340}\left(\epsilon_{\mathrm{NADH}}=6.22 \times 10^{3} \mathrm{M}^{-1} \mathrm{~cm}^{-1}\right)$ as a function of time.

To $980 \mathrm{uL}$ of the reaction buffer $(100 \mathrm{mM} \mathrm{KCl}, 50 \mathrm{mM}$ Hepes-KOH, $\mathrm{pH} 7.0,1.5 \mathrm{mM} \mathrm{\textrm {MCl } _ { 2 }}, 10 \mathrm{mg} / \mathrm{mL} \mathrm{PEP}, 30 \mathrm{units} / \mathrm{mL}$ PK, 70 units/mL LDH, $0.4 \mathrm{mM} \mathrm{NADH),} 5 \mu \mathrm{M} \mathrm{A23187}$ and $2.0 \mathrm{mM}$ $\mathrm{Mg}^{2+}$-ATP were added, mixed, and the absorbance allowed to level off. The reaction was started by the addition of $0.08 \mathrm{mg} / \mathrm{mL} \mathrm{SR}$. The initial decrease in $\mathrm{Abs}_{340}$, as a function of change in time, was used to calculate the ATPase activity by the following equation:

eq 3: $\quad$ ATPase activity $=$ change in $\mathrm{Abs}_{340}$

(change in time, minutes) (6.22 $\left.\times 10^{-3} \mu \mathrm{M}^{-1}\right)(\mathrm{mg} \mathrm{SR}, \mathrm{mg} / \mathrm{L})$

SR vesicles were irradiated in the presence of rose bengal for 1 minute prior to dilution into the reaction buffer. After irradiation, ATPase activity was determined by monitoring the decrease in absorbance at $340 \mathrm{~nm}$ as a function of time. ATPase activity remaining was reported as a percentage and was calculated by dividing the ATPase of the rose bengal-treated sample by the ATPase activity of a sample containing no rose bengal.

\section{GEL ELECTROPHORESIS}

Polyacrylamide gel electrophoresis of SR proteins was performed according to a modification of the Laemmi method 
(104). SR proteins were solubilized with sodium dodecyl sulfate (SDS), applied to a polyacrylamide slab gel, and subjected to electrophoresis. Following SDS binding to the proteins the mass/charge ratio was the same for all proteins, and the proteins separated according to their mass. Standards of known molecular weight were run for comparison. The $\mathrm{R}_{\mathrm{f}}$ of the standards and protein bands were deternined by the following equation:

eq $4: \quad R_{f}=\frac{\text { distance of protein migration }}{\text { distance of dye front migration }}$

The $R_{f}$ values of the protein standards were then plotted as a function of the log of their molecular mass. The log of the molecular mass of the unknown proteins could then be determined from a graph of $R_{f}$ versus log molecular weight.

A running gel of $7 \%$ polyacrylamide buffered to $\mathrm{pH} 8.8$ was used. A stacking gel of $4 \%$ polyacrylamide, $\mathrm{pH} 6.8$, was layered on top of the running gel. The purpose of the stacking gel was to force SDS-solubilized proteins to enter the running gel at the same time. Between 25-50 $\mu \mathrm{g}$ of $\mathrm{SR}$ proteins was applied to each well and subjected to electrophoresis under a constant voltage of $100 \mathrm{mV}$. When the dye front reached the bottom of the running gel, the electric field was turned off. The gels were then stained in a Coomassie Blue staining solution for several hours. The gels were then destained in methanol/acetic acid until the background was essentially colorless. A densitometer 
was used to determine the relative density of the different protein components of the SR.

\section{ASOLECTIN VESICLES}

Asolectin vesicles were prepared without the incorporation of protein to determine the effect of the photooxidizing dyes on the phospholipids of the vesicles.

Asolectin, $60 \mathrm{mg}$, was diluted with $1.0 \mathrm{~mL}$ of distilled deionized $\mathrm{H}_{2} \mathrm{O}$ and homogenized until a uniform suspension was obtained. The suspension was purged with $\mathrm{N}_{2}$ gas and sonicated for $15-20$ minutes. During sonication, the suspension was repurged with $\mathrm{N}_{2}$ gas. After sonication, $50 \mu \mathrm{L}$ of the asolectin vesicles suspension (ALV) was added to $100 \mu \mathrm{L}$ of $200 \mathrm{mM} \mathrm{KCl}, 100 \mathrm{mM}$ Hepes, $\mathrm{pH} 7.0$ buffer, 2.5 $\mu \mathrm{L}$ of $100 \mathrm{mM} \mathrm{Ca}{ }^{2+}$ and $97.5 \mu \mathrm{L}$ of distilled deionized $\mathrm{H}_{2} \mathrm{O}$. The vesicles were immediately frozen in liquid nitrogen and thawed at room temperature for 15 minutes. The ALV were then sonicated for 30 seconds. The ALV, now containing $\mathrm{Ca}^{2+}$ on the inside, were ready to use for $\mathrm{Ca}^{2+}$ permeability studies.

ALV, $20 \mu \mathrm{L}$, were diluted into an effluxing buffer containing $100 \mathrm{mM} \mathrm{KCL}, 50 \mathrm{mM}$ Hepes, $\mathrm{pH} 7.0,3 \mathrm{mM} \mathrm{MgCl}_{2}, 100$ $\mu \mathrm{M}$ AsIII. A base line was set and A23187 was added to release internal $\mathrm{Ca}^{2+}$. The internal $\mathrm{Ca}^{2+}$ was determined after treatment with $0 \mu \mathrm{M}$ rose bengal, $1 \mu \mathrm{M}$ rose bengal 
(irradiated for 1 or 2 minutes), and $10 \mu \mathrm{M}$ rose bengal (incubated in the dark for 4 or 8 minutes).

CALCIUM UPTAKE OF ROSE BENGAL-TREATED SR VESICLES

$\mathrm{Ca}^{2+}$ uptake was measured using the $\mathrm{Ca}^{2+}-$ sensitive dye, APIII. SR vesicles $(0.2 \mathrm{mg} / \mathrm{mL})$ were incubated in an uptake buffer $\left(100 \mathrm{mM} \mathrm{KCl}, 1 \mathrm{mM} \mathrm{MgCl}_{2}\right.$, $50 \mathrm{mM}$ Hepes, $\mathrm{pH} 7.0,20 \mu \mathrm{M}$ $\mathrm{CaCl}_{2}$ ) in the presence or absence of rose bengal. The sample was irradiated for 1 minute. Irradiation was then stopped, $100 \mu \mathrm{M}$ APIII added, and $1 \mathrm{mM} \mathrm{Mg}^{2+}-\mathrm{ATP}$ added to initiate uptake. After uptake was completed, as evidenced by the leveling off of the signal, A23187 was added to release the accumulated $\mathrm{Ca}^{2+}$. The AP III/Ca ${ }^{2+}$ signal was calibrated by the addition of $2-4 \mu \mathrm{M} \mathrm{Ca}^{2+}$. The percentage uptake activity remaining was determined by dividing the amount of $\mathrm{Ca}^{2+}$ uptake in the irradiated sample by the amount of $\mathrm{Ca}^{2+}$ uptake in the control (without rose bengal).

\section{SINGLET OXYGEN PRODUCTION}

Singlet oxygen production was measured by the RNO bleaching method described by Kraljic and Mohsni (105) (see $\mathrm{rx}$ 2-5) . 40-50 $\mu \mathrm{M}$ p-nitrosodimethylaniline (RNO), $8 \mathrm{mM}$ imidazole and $3 \mu \mathrm{M}$ rose bengal or $10 \mu \mathrm{M}$ methylene blue were added to a $100 \mathrm{mM} \mathrm{KCl}, 50 \mathrm{mM}$ Hepes, $\mathrm{pH} 7.0$ buffer in the presence or absence of $10 \mu \mathrm{M}$ ruthenium red. Samples were irradiated with a 360-watt broad spectrum lamp at a 
distance of $30 \mathrm{~cm}$ (shielded with a beaker of water). Aliquots were removed at various times and the $\mathrm{Abs}_{440}$ was recorded. Controls in the dark and in the absence of sensitizer dye were performed. In the equations below $D$ represents the sensitizer, rose bengal or methylene blue; $A$ represents imidazole; and $\left(\mathrm{AO}_{2}\right)$ represents a transannular peroxide intermediate in the reaction between imidazole and singlet oxygen. RNO represents p-nitrosodimethylaniline and -RNO represents the bleached species of RNO.

$$
\begin{aligned}
& \text { rx 2: } \mathrm{D}+\mathrm{hv} \longrightarrow-{ }^{1} \mathrm{D}^{*}-\ldots-\ldots->{ }^{3} \mathrm{D} \\
& \mathrm{rx} \mathrm{3:} \quad{ }^{3} \mathrm{D}+\mathrm{O}_{2}-\rightarrow \mathrm{D}+{ }^{1} \mathrm{O}_{2} \\
& \mathrm{rx} 4: \quad \mathrm{l}_{2}+\mathrm{A}-\rightarrow\left(\mathrm{AO}_{2}\right) \rightarrow-\rightarrow \mathrm{AO}_{2} \\
& \text { rX 5: }\left(\mathrm{AO}_{2}\right)+\mathrm{RNO}--->\quad \text {-RNO + various products }
\end{aligned}
$$

In all figures and tables where no error bars are shown, the typical errors are less than $20 \%$ of the value displayed.

\section{MATERIALS}

All materials were purchased from Sigma Chemical Company (St. Louis, Missouri) except for the following: DTT and Hepes buffer were purchased from Research Organics (Cincinnati, ohio): imidazole was purchased for Aldrich Chemical Company; Chelex-100 (50-100 mesh) was purchased from Bio-Rad and ultrapure sucrose was purchased from Schwarz-Mann; ${ }^{45} \mathrm{Ca}^{2+}$ was obtained from New England Nuclear; 
and solvent free liquid scintillation fluid was obtained from Isolab, Inc.

\section{ABBREVIATIONS}

SR, sarcoplasmic reticulum; HSR, heavy sarcoplasmic reticulum; LSR, light sarcoplasmic reticulum; Hepes, 4-(2hydroxyethyl)-1-piperazineethanesulfonic acid; adenosine 5'-triphosphate; $\mathrm{ACPO}_{4}$, acetyl phosphate; GTP, guanosine 5'-triphosphate; ITP, inosine 5'-triphosphate; CTP, cytosine 5'-triphosphate; UTP, uridine 5'triphosphate; AMP-PCP, $\beta-\gamma$-methyleneadenosine $5^{\prime}-$ triphosphate; CAMP, adenosine $3^{\prime}: 5^{\prime}$ cyclic monophosphate; AsIII, arsenazo III; APIII, antipyrylazo III; SOD, superoxide dismutase; EFA, ethoxyformic anhydride; RNO, pnitrosodimethylaniline: $\mathrm{NADH}, \quad \beta$-nicotinamide adenine dinucleotide, reduced form; NAD, $\beta$-nicotinamide adenine dinucleotide, oxidized form; LDH, lactic dehydrogenase; PK, pyruvate kinase; PEP, phosphoenolpyruvate; SDS, sodium dodecyl sulfate; PAGE, polyacrylamide gel electrophoresis; ALV, asolectin vesicles; DTT, dithiothreitol. 
CHAPTER III

ADENINE NUCLEOTIDES STIMULATE OXIDATION-INDUCED CALCIUM EFFLUX FROM SARCOPLASMIC RETICULUM VESICLES

\section{SUMMARY}

Micromolar concentrations of copper $\left(\mathrm{Cu}^{2+}\right)$ and cysteine induce rapid efflux of $\mathrm{Ca}^{2+}$ from $\mathrm{SR}$ vesicles. This effect appears to be due to a $\mathrm{Cu}^{2+}$-catalyzed oxidation of the added cysteine to a critical sulfhydryl group on the release protein from SR (22). The data presented here indicate that adenine nucleotides synergistically stimulate $\mathrm{Cu}^{2+} /$ cysteine (oxidation)-induced $\mathrm{Ca}^{2+}$ efflux from SR vesicles. The order of effectiveness in stimulating $\mathrm{Ca}^{2+}$ efflux is ATP $>$ AMP-PCP $>$ CAMP $>$ adenine $\sim$ NAD $\sim$ NADH. Non-adenine containing nucleotides such as GTP, CTP, UTP, ITP and the high energy phosphate compound, acetyl phosphate, were ineffective in stimulating oxidationinduced $\mathrm{Ca}^{2+}$ efflux. The relative effectiveness of various adenine nucleotides in stimulating $\mathrm{Ca}^{2+}$-induced $\mathrm{Ca}^{2+}$ efflux and oxidation-induced $\mathrm{Ca}^{2+}$ efflux are identical, suggesting that a common mode of action is involved when $\mathrm{Ca}^{2+}$ release is triggered by either method. The stimulatory effect of the adenine nucleotides on oxidation-induced efflux is independent of external $\mathrm{Mg}^{2+}$ concentration and independent of the $\mathrm{Mg}^{2+}$ gradient across the SR membrane. 
INTRODUCTION

It is well established that physiological contraction and relaxation of skeletal muscle are regulated by the SR which controls the myoplasmic $\mathrm{Ca}^{2+}$ concentration (59). The $\mathrm{Ca}^{2+}$ pump protein from SR hydrolyzes ATP and actively accumulates $\mathrm{Ca}^{2+}$ into the SR. This lowers the myoplasmic $\mathrm{Ca}^{2+}$ concentration and leads to relaxation of the muscle. Rapid efflux of $\mathrm{Ca}^{2+}$ from the $\mathrm{SR}$ leads to muscle contraction. The molecular mechanism of $\mathrm{Ca}^{2+}$ release from the SR remains the least well understood step in excitation-contraction coupling (10).

The most widely accepted theory of how depclarization of the transverse tubule triggers release of $\mathrm{Ca}^{2+}$ from the $\mathrm{SR}$ is $\mathrm{Ca}^{2+}$-induced $\mathrm{Ca}^{2+}$ release. This theory states that micromolar concentrations of $\mathrm{Ca}^{2+}$ serve as a chemical messenger to signal the opening of a $\mathrm{Ca}^{2+}$ release channel on the SR. $\mathrm{Ca}^{2+}$-induced $\mathrm{Ca}^{2+}$ release is inhibited by local anesthetics (62), ruthenium red (54), and high concentrations of $\mathrm{Mg}^{2+}(54,263,106)$ and is stimulated by caffeine (57-58, 62, 107) and adenine nucleotides (57-58, 63, 68-69, 108). Smith et al. (109) have directly demonstrated the presence of $\mathrm{Ca}^{2+}$ channels in SR which are inhibited by ruthenium red, stimulated by ATP, and capable of conducting $\mathrm{Mg}^{2+}$.

Trimm et al. (22) have previously reported that the oxidation of a critical sulfhydryl on the SR membrane 
induces a rapid efflux of $\mathrm{Ca}^{2+}$. Oxidation-induced $\mathrm{Ca}^{2+}$ efflux is inhibited by $\mathrm{Mg}^{2+}$, ruthenium red, and local anesthetics. Also, SR derived from the terminal cisternae region (HSR) is much more sensitive to oxidation-induced $\mathrm{Ca}^{2+}$ efflux than SR derived from the longitudinal SR (LSR). In this chapter it is shown that adenine nucleotides synergistically stimulate oxidation-induced efflux of $\mathrm{Ca}^{2+}$ from SR vesicles, indicating that these two types of affectors of $\mathrm{Ca}^{2+}$ release influence two interacting sites on the $\mathrm{Ca}^{2+}$ release protein from skeletal muscle SR.

\section{RESULTS}

Trimm et al. (22) have previously shown that the addition of $\mathrm{Cu}^{2+}$ and cysteine to actively loaded vesicles causes a rapid efflux of accumulated $\mathrm{Ca}^{2+}$. Here it has been observed that vesicles actively loaded with $\mathrm{Ca}^{2+}$ using ATP as the substrate for the $\mathrm{Ca}^{2+}$ pump have an oxidationinduced efflux rate approximately 5 times greater than that of passively loaded vesicles. It appear that the presence of ATP stimulates oxidation-induced $\mathrm{Ca}^{2+}$ efflux from SR vesicles.

To test this hypothesis, $S R$ vesicles were actively loaded using acetyl phosphate and $\mathrm{Ca}^{2+}$ efflux was induced with $\mathrm{Cu}^{2+} /$ cysteine and/or various adenine containing nucleotides (Figure 3). The vesicles were allowed to accumulate added $\mathrm{Ca}^{2+}(10 \mu \mathrm{M})$ in the presence of $10 \mu \mathrm{M}$ 
cysteine and $0.5 \mathrm{mM}$ acetyl phosphate or $0.5 \mathrm{mM}$ ATP at a free $\mathrm{Mg}^{2+}$ concentration of $3 \mathrm{mM}$. After the added $\mathrm{Ca}^{2+}$ was accumulated, efflux was stimulated by the addition of $4 \mu \mathrm{M}$ $\mathrm{Cu}^{2+}$ and/or $0.5 \mathrm{mM}$ of various adenine nucleotides. (Note that $\mathrm{Ca}^{2+}$ uptake was recorded on a time scale 10 times slower than that for $\mathrm{Ca}^{2+}$ release.) Figure 3 shows that the addition of adenine nucleotides stimulates oxidationinduced $\mathrm{Ca}^{2+}$ efflux. The order of stimulating effectiveness is ATP > AMP-PCP > CAMP > AMP. The total amount of $\mathrm{Ca}^{2+}$ effluxed was approximately $50-60 \%$ in the presence of adenine nucleotides and approximately $25-30 \%$ in their absence.

To determine whether the stimulation of $\mathrm{Ca}^{2+}$ efflux is due to the adenine moiety or to the triphosphate, nonadenine nucleotide triphosphates were tested. $\mathrm{Cu}^{2+} /$ cysteine-induced efflux rates from vesicles actively loaded using ATP, $\mathrm{ACPO}_{4}$, or various non-adenine nucleotides (GTP, UTP, CTP, and ITP) are reported in Table I. SR vesicles were actively loaded (in the presence of $10 \mu \mathrm{M}$ cysteine) with $10 \mu \mathrm{L} \mathrm{Ca}^{2+}$ using various non-adenine nucleotides as substrate for the ATPase. Under these conditions vesicles were submaximally loaded such that after accumulation of the $\mathrm{Ca}^{2+}$ the extravesicular $\mathrm{Ca}^{2+}$ concentration in all experiments was less than $1 \mu \mathrm{M}$. At 


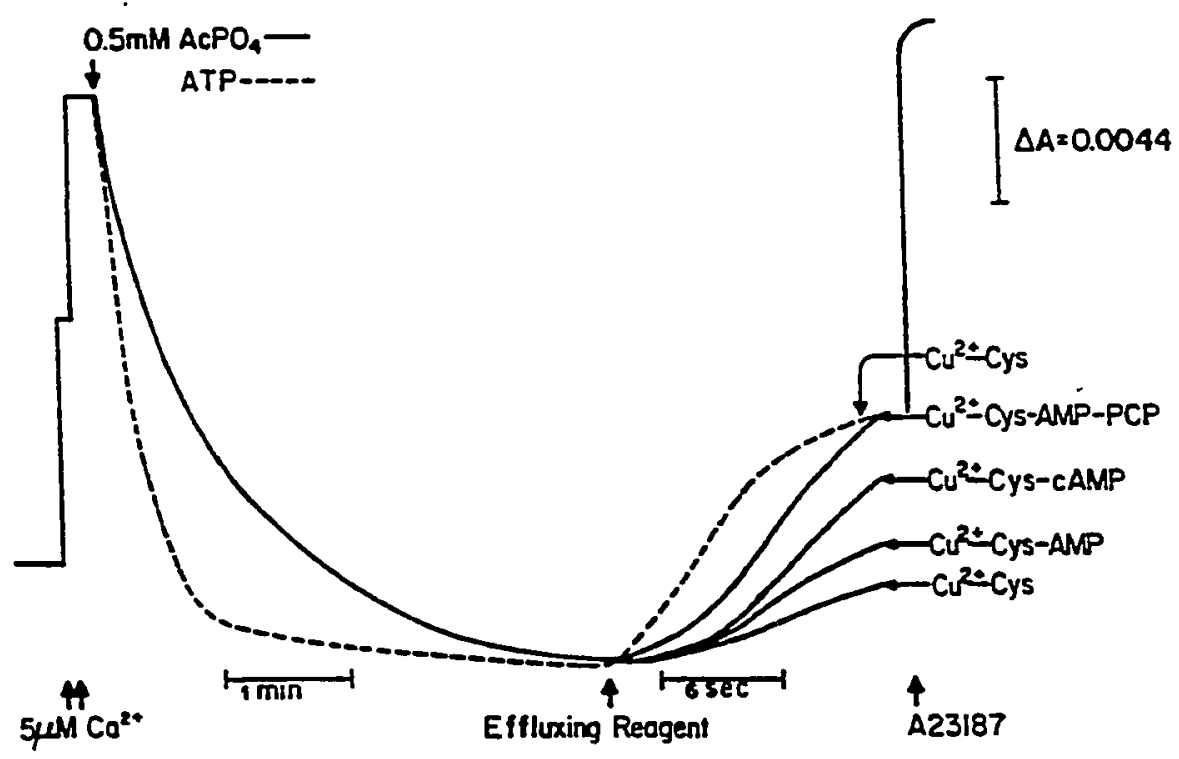

Figure 3. Adenine nucleotide stimulation of $\mathrm{Ca}^{2+}$ efflux from actively loaded SR vesicles. SR vesicles were diluted into uptake buffer, $\mathrm{pH} 6.8$ containing $10 \mu \mathrm{M}$ cysteine and $100 \mu \mathrm{M}$ AsIII to a final protein concentration of $0.15 \mathrm{mg} / \mathrm{mL}$ and the change in $\mathrm{Abs}_{675}$ - Abs 685 was monitored, as a function of time. Two allquots of $5 \mu \mathrm{M} \mathrm{Ca}^{2+}$ were added and uptake was initiated by the addition of either $0.5 \mathrm{mM} \mathrm{Mg}^{2+} \mathrm{ATP}_{\mathrm{P}}$ or $0.5 \mathrm{mM} \mathrm{AcPO} 4_{4}$ After accumulation of the $\mathrm{Ca}^{2+}$ efflux was initiated by the addition of $4 \mu \mathrm{M} \mathrm{Cu}^{2+}$ or $4 \mu \mathrm{M} \mathrm{Cu}^{2+}$ plus 0.5 $\mathrm{mM}$ adenine nucleotide. Approximately $0.8 \mu \mathrm{M}$ A23187 was added at the end of the experiment. 
TABLE I

EFFECT OF NON-ADENINE NUCLEOTIDES ON COPPER/CYSTEINE-INDUCED CALCIUM EFFLUX RATE

\begin{tabular}{lcc}
\hline Substrate & $\begin{array}{c}\text { Efflux rate } \\
\text { (nmol/mg-sec) }\end{array}$ & \%Effluxed \\
\hline ATP & 4.4 & 49 \\
AcPO & 1.1 & 30 \\
GTP & 0.9 & 27 \\
ITP & 1.2 & 28 \\
UTP & 0.8 & 30 \\
CTP & 1.0 & 28 \\
\hline
\end{tabular}

SR vesicles were actively loaded as described in Figure 3 using various substrates. Efflux was initiated by the addition of $4 \mu \mathrm{M} \mathrm{Cu}{ }^{2+}$. The percentage $\mathrm{Ca}^{2+}$ effluxed was determined by dividing the amount of $\mathrm{Ca}^{2+}$ effluxed after addition of $\mathrm{Cu}^{2+} /$ cysteine (calculated from the change of absorbance from the time that the releasing reagent is added to the time. that the absorbance levels off) by the total initial internal $\mathrm{Ca}^{2+}$ content of the vesicle (determined by adding A23187 to the actively loaded SR vesicle). Vesicles loaded using ATP as the substrate had $-4 \mathrm{x}$ greater efflux rates than vesicles loaded using nonadenine substrates. 
this point, efflux was initiated by the addition of $4 \mu \mathrm{M}$ $\mathrm{Cu}^{2+}$. The oxidation-induced $\mathrm{Ca}^{2+}$ efflux rates from vesicles loaded using non-adenine nucleotides were approximately the same as the rates obtained from $\mathrm{AcPO}_{4}$ loaded vesicles. The total amount of $\mathrm{Ca}^{2+}$ effluxed was 25$30 \%$ as compared to $\sim 50 \%$ from ATP loaded vesicles. The stimulation of the $\mathrm{Ca}^{2+}$ efflux rate triggered by $\mathrm{Cu}^{2+} /$ cysteine is observed only in the presence of the adenine moiety.

To ensure that the adenine nucleotide stimulation of $\mathrm{Ca}^{2+}$ release is not an indirect effect on the $\mathrm{Ca}^{2+}$ pump, $\mathrm{Ca}^{2+}$ efflux from passively loaded $S R$ vesicles was measured in the absence of $\mathrm{Ca}^{2+}$ pump substrate. Under these experimental conditions $\left(100 \mathrm{mM} \mathrm{KCl}, 3 \mathrm{mM} \mathrm{Mg}^{2+}, \mathrm{pH} 6.8\right.$, using $100 \mu \mathrm{M}$ AsIII), $0.5 \mathrm{mM}$ AMP-PCP by itself caused no measurable $\mathrm{Ca}^{2+}$ efflux. However, when added simultaneously with $4 \mu \mathrm{M} \mathrm{Cu}{ }^{2+}$ (10 $\mu \mathrm{M}$ cysteine in the effluxing buffer) the efflux rate was 5-6 times larger than that with $\mathrm{Cu}^{2+} /$ cysteine alone. Adenine nucleotides also stimulated silver-induced $\mathrm{Ca}^{2+}$ efflux (Table II). When $1 \mu \mathrm{M} \mathrm{Ag}^{+}$was added to passively loaded vesicles the rate of $\mathrm{Ca}^{2+}$ efflux observed was only slightly higher than oxidation-induced

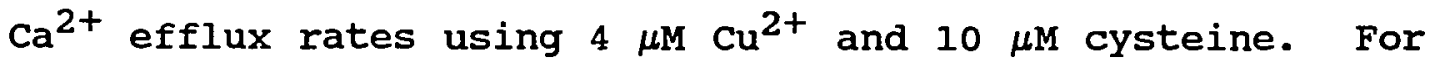
most entries in Table II, adenine nucleotides stimulate $\mathrm{Ag}^{+}$-induced $\mathrm{Ca}^{2+}$ efflux more than they stimulate $\mathrm{Cu}^{2+} /$ cysteine-induced $\mathrm{Ca}^{2+}$ efflux. However, adenine 
TABLE II

EFFECT OF VARIOUS COMPOUNDS ON OXIDATION-STIMULATED $\mathrm{Ca}^{2+}$ EFFLUX FROM PASSIVELY LOADED VESICLES

\begin{tabular}{|c|c|c|c|c|c|}
\hline \multicolumn{3}{|c|}{ Effluxing reagent } & $\begin{array}{l}\text { Efflux rate } \\
\text { (nmol/mg-sec) }\end{array}$ & $\begin{array}{l}\text { Stimulation } \\
\text { factor }\end{array}$ & \% Effluxed \\
\hline $\begin{array}{l}\text { Copper-cystei } \\
\text { +Adenine } \\
\text { +AMP } \\
\text { +CAMP } \\
\text { +AMP-PCP } \\
\text { +NAD } \\
\text { +NADH }\end{array}$ & $\begin{array}{l}\text { ne } \\
(0.5 \\
10.5 \\
(0.5 \\
10.5 \\
10.5 \\
10.5\end{array}$ & $\begin{array}{l}\mathrm{mM} \text { ) } \\
\mathrm{mM} \text { ) } \\
\mathrm{mM} \text { ) } \\
\mathrm{mM} \text { ) } \\
\mathrm{mM} \text { ) } \\
\mathrm{mM} \text { ) }\end{array}$ & $\begin{array}{l}0.28 \\
0.63 \\
0.94 \\
1.49 \\
1.57 \\
0.47 \\
0.67\end{array}$ & $\begin{array}{l}1.0 \\
2.3 \\
3.4 \\
5.3 \\
5.6 \\
1.7 \\
2.4\end{array}$ & $\begin{array}{l}63 \\
60 \\
70 \\
68 \\
72 \\
53 \\
60\end{array}$ \\
\hline $\begin{array}{l}\text { Silver } \\
\text { +Adenine } \\
\text { +AMP } \\
\text { +CAMP } \\
\text { +AMP-PCP } \\
\text { +NAD } \\
\text { +NADH }\end{array}$ & $\begin{array}{l}0.5 \\
(0.5 \\
(0.5 \\
(0.5 \\
(0.5 \\
10.5\end{array}$ & $\begin{array}{l}\mathrm{mM} \text { ) } \\
\mathrm{mM} \text { ) } \\
\mathrm{mM} \text { ) } \\
\mathrm{mM} \text { ) } \\
\mathrm{mM} \text { ) } \\
\mathrm{mM} \text { ) }\end{array}$ & $\begin{array}{l}0.40 \\
1.05 \\
1.21 \\
3.30 \\
3.50 \\
0.69 \\
0.79\end{array}$ & $\begin{array}{l}1.0 \\
2.6 \\
3.0 \\
8.3 \\
8.8 \\
1.7 \\
2.0\end{array}$ & $\begin{array}{l}38 \\
63 \\
58 \\
71 \\
72 \\
55 \\
63\end{array}$ \\
\hline $\begin{array}{l}\text { Adenine } \\
\text { nucleotides }\end{array}$ & $(0.5$ & $\mathrm{mM}$ ) & $<0.1$ & & \\
\hline
\end{tabular}

SR vesicles were passively loaded as described in Figure 4. Efflux was initiated by the addition of $4 \mu \mathrm{M}$ $\mathrm{Cu}^{2+} / 10 \mu \mathrm{M}$ cysteine or $1 \mu \mathrm{M} \mathrm{Ag}^{+}$. Various nucleotides $(0.5$ $\mathrm{mM}$ ) were simultaneously added with either the $\mathrm{Cu}^{2+} /$ cysteine or silver. The stimulation factor is the ratio of the efflux rate with added nucleotide to the efflux rate without added nucleotide. The percentage $\mathrm{Ca}^{2+}$ effluxed was determined by dividing the amount of $\mathrm{Ca}^{2+}$ effluxed after addition of either $\mathrm{Ag}^{+}$or $\mathrm{Cu}^{2+} /$ cysteine plus nucleotide (determined when there was no further change in absorbance) by the total initial internal $\mathrm{Ca}^{2+}$ content of the vesicle, as determined by adding A23187 to the passively loaded SR vesicle. 
nucleotides synergistically stimulate both oxidationinduced and $\mathrm{Ag}^{+}$-induced $\mathrm{Ca}^{2+}$ efflux from $\mathrm{SR}$ vesicles with the order of effectiveness being:

$$
\text { AMP-PCP > CAMP > AMP > adenine NAD NADH }
$$

These data suggest that the complete adenine nucleotide (purine + ribose + phosphates) may be required for maximal stimulation. The fact that AMP-PCP, which is nonhydrolyzable, is the most potent stimulator suggests that only the binding of the adenine nucleotide, not the hydrolysis of a phosphate bond or phosphorylation of a protein, is necessary for stimulation. The requirement for the adenine moiety is supported by the fact that nonadenine nucleotides do not enhance the oxidation-induced efflux rate (Table I). However, non-adenine nucleotides can support active accumulation of $\mathrm{Ca}^{2+}$ by the vesicles.

Figure 4 shows that AMP-PCP plus $\mathrm{Cu}^{2+} /$ cysteine exhibit Michaelis-Menten efflux kinetics with respect to nucleotide concentration. Vesicles were passively loaded with $1 \mathrm{mM}$ $\mathrm{Ca}^{2+}$ and allowed to equilibrate overnight at $0^{\circ} \mathrm{C}$. The vesicles were then diluted $50 x$ into the effluxing buffer containing $10 \mu \mathrm{M}$ cysteine to yield an external $\mathrm{Ca}^{2+}$ concentration of approximately $20 \mu \mathrm{M}$. Efflux was initiated

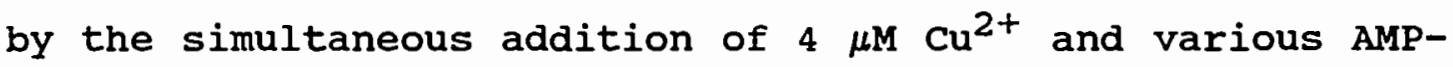
PCP concentrations. Under these experimental conditions $\mathrm{V}_{\max }$ was $1.4 \mathrm{nmol} / \mathrm{mg}-\mathrm{s}$ and the $\mathrm{K}_{\mathrm{m}}$ was $0.14 \mathrm{mM}$. 

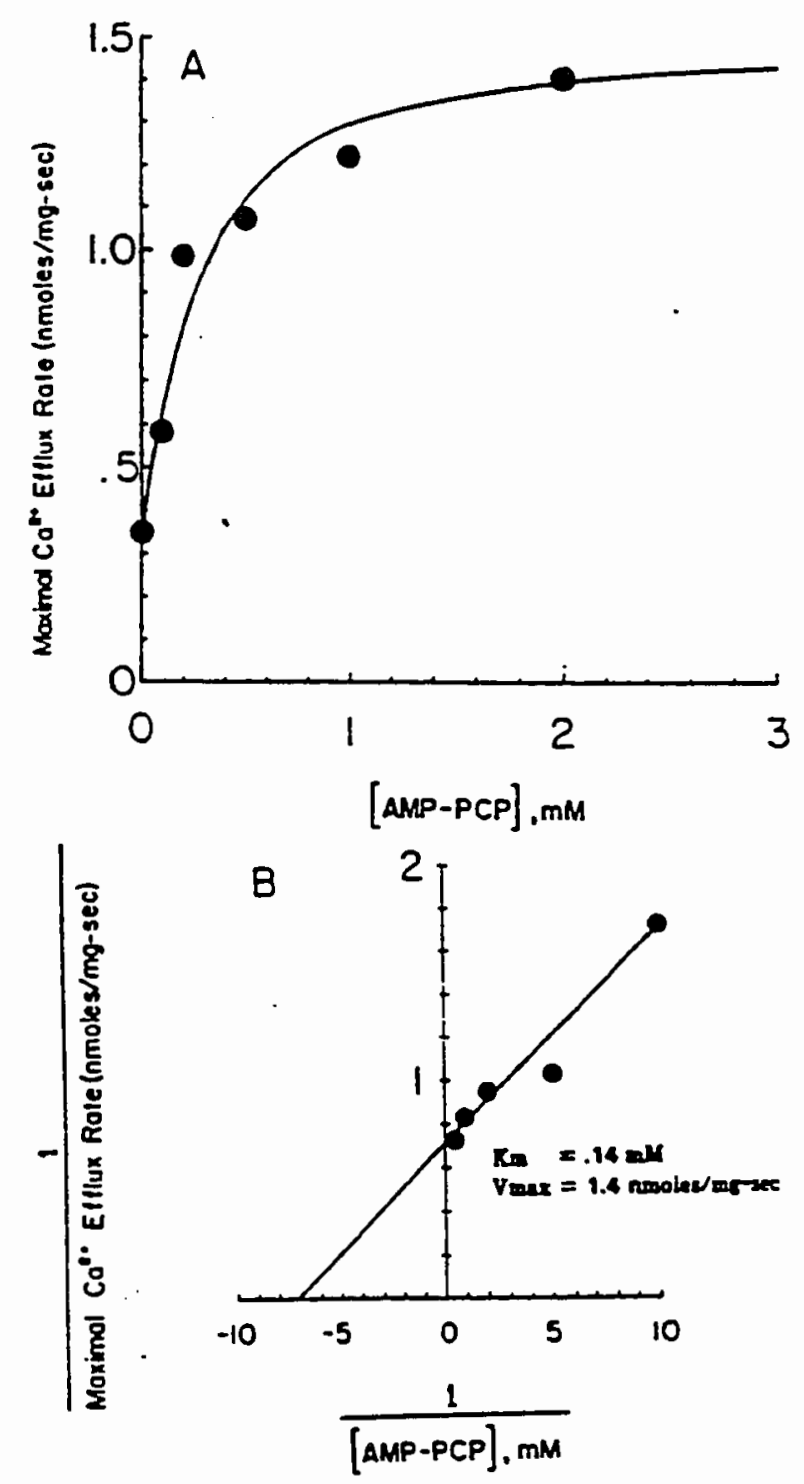

Figure 4. Effect of AMP-PCP concentration on oxidation-induced $\mathrm{Ca}^{2+}$ efflux. SR vesicles were incubated overnight at $0^{\circ} c$ in a medium containing $100 \mathrm{mM} \mathrm{KCl}, 3 \mathrm{mM} \mathrm{Mg}{ }^{2+}, 1 \mathrm{mM} \mathrm{Ca}{ }^{2+}, 50$ $\mathrm{mM}$ Hepes, $\mathrm{pH}$ 6.8. Vesicles were diluted in effluxing buffer containing $100 \mathrm{mM} \mathrm{KCl}, 3 \mathrm{mM}$ $\mathrm{Mg}^{2+}, 10 \mu \mathrm{M}$ cysteine, $100 \mu \mathrm{M}$ AsIII, $50 \mathrm{mM}$ Hepes, $\mathrm{pH}$ 6.8. The final protein concentration was 0.15 $\mathrm{mg} / \mathrm{mL}$. $\mathrm{Cu}^{2+}(4 \mu \mathrm{M})$ and various concentrations of magnesium AMP-PCP were added to induce $\mathrm{Ca}^{2+}$ efflux. (A) The efflux rates as a function of AMP-PCP concentration. (B) A Lineweaver-Burk plot of the data. $\mathrm{K}_{\mathrm{M}}=0.14 \mathrm{mM}$ and $\mathrm{V}_{\max }=1.4$ nmol/mg-sec. 
Efflux rates from ATP actively loaded vesicles [4.4 nmol/mg-s (Table I)] were approximately 3.0 times higher than the $V_{\max }[1.4$ nmol/mg-s (Figure 4)] observed using AMP-PCP to stimulate $\mathrm{Ca}^{2+}$ efflux from passively loaded vesicles. It appears as if ATP was more effective in stimulating $\mathrm{Cu}^{2+} /$ cysteine-induced $\mathrm{Ca}^{2+}$ efflux than AMP-PCP. However, in order to quantify the difference between ATP and AMP-PCP stimulation of oxidation-induced $\mathrm{Ca}^{2+}$ release the experimental conditions in the two experiments must be more similar. To further examine this observation, $\mathrm{Ca}^{2+}$ efflux induced by $\mathrm{Cu}^{2+} /$ cysteine or $\mathrm{Cu}^{2+} /$ cysteine $+0.2 \mathrm{mM}$ $\mathrm{Mg}^{2+}-\mathrm{ATP}$ or $\mathrm{Cu}^{2+} /$ cysteine $+0.2 \mathrm{mM} \mathrm{Mg}^{2+}-\mathrm{AMP}-\mathrm{PCP}$ was measured from actively loaded vesicles (using $\mathrm{AcPO}_{4}$ as substrate). The efflux rates were $1.6 \pm 0.2,4.1 \pm 0.2$, and $3.2 \pm 0.4 \mathrm{nmol} / \mathrm{mg}-\mathrm{sec}$, respectively. Under these conditions ATP is 1.3 times more effective than AMP-PCP in stimulating $\mathrm{Cu}^{2+} /$ cysteine-induced $\mathrm{Ca}^{2+}$ release. During passive efflux experiments $72 \%$ of internal $\mathrm{Ca}^{2+}$ exits in the presence of AMP-PCP and $\mathrm{Cu}^{2+} /$ cysteine (Table II), while during active experiments in the presence of ATP approximately 50\% (Table I) of accumulated $\mathrm{Ca}^{2+}$ exits. This discrepancy is apparently due to the $\mathrm{Ca}^{2+}$ pump reaccumulating some of the $\mathrm{Ca}^{2+}$ released by the $\mathrm{Cu}^{2+} /$ cysteine in the presence of pump substrate.

oxidation-induced $\mathrm{Ca}^{2+}$ efflux is known to be inhibited at high $\mathrm{Mg}^{2+}$ concentrations (22). In Figure 5, the $\mathrm{Mg}^{2+}$ 
dependence of AMP-PCP stimulation of oxidation-induced $\mathrm{Ca}^{2+}$ efflux was examined. Vesicles were incubated overnight in a $1 \mathrm{mM} \mathrm{Ca}{ }^{2+}$ buffer with varying concentrations of $\mathrm{Mg}^{2+}$. The vesicles were then diluted into a $\mathrm{Ca}^{2+}$-free buffer containing the same concentration of $\mathrm{Mg}^{2+}$ with $10 \mu \mathrm{M}$ cysteine present. There was no $\mathrm{Mg}^{2+}$ gradient across the vesicle. Efflux was initiated by either $2 \mu \mathrm{M} \mathrm{Cu}{ }^{2+}$ or $2 \mu \mathrm{M}$ $\mathrm{Cu}^{2+}+0.5 \mathrm{mM} \mathrm{Mg}^{2+}-\mathrm{AMP}-\mathrm{PCP}$. At high concentrations of $\mathrm{Mg}^{2+}$ both the oxidation-induced efflux and the adeninestimulated oxidation-induced efflux were inhibited. There is, however, a constant difference between the two curves, indicating that the AMP-PCP stimulation of $\mathrm{Cu}^{2+} /$ cysteineinduced efflux is $\mathrm{Mg}^{2+}$ independent.

To determine if $\mathrm{Ca}^{2+}$ efflux rates are affected by a $\mathrm{Mg}^{2+}$ gradient across the $\mathrm{SR}$, vesicles were incubated overnight in a $1 \mathrm{mM} \mathrm{Ca}^{2+}$ buffer containing varying $\mathrm{Mg}^{2+}$ concentrations $(0,3$, and $30 \mathrm{mM})$ and diluted into a similar $\mathrm{Ca}^{2+}$-free buffer with $3 \mathrm{mM} \mathrm{Mg}^{2+}$. As seen in Figure $6 \mathrm{~A}$ there is an apparent inhibition of efflux rates by increased internal $\mathrm{Mg}^{2+}$. As the concentration of the internal $\mathrm{Mg}^{2+}$ increased, the internal $\mathrm{Ca}^{2+}$ present at equilibrium decreased (at 0,3 , and $30 \mathrm{mM}$ internal $\mathrm{Mg}^{2+}$ the releasable internal $\mathrm{Ca}^{2+}$ was $6.4,5.4$, and $2.7 \mu \mathrm{M}$, respectively). If the efflux rate is normalized, (divide 


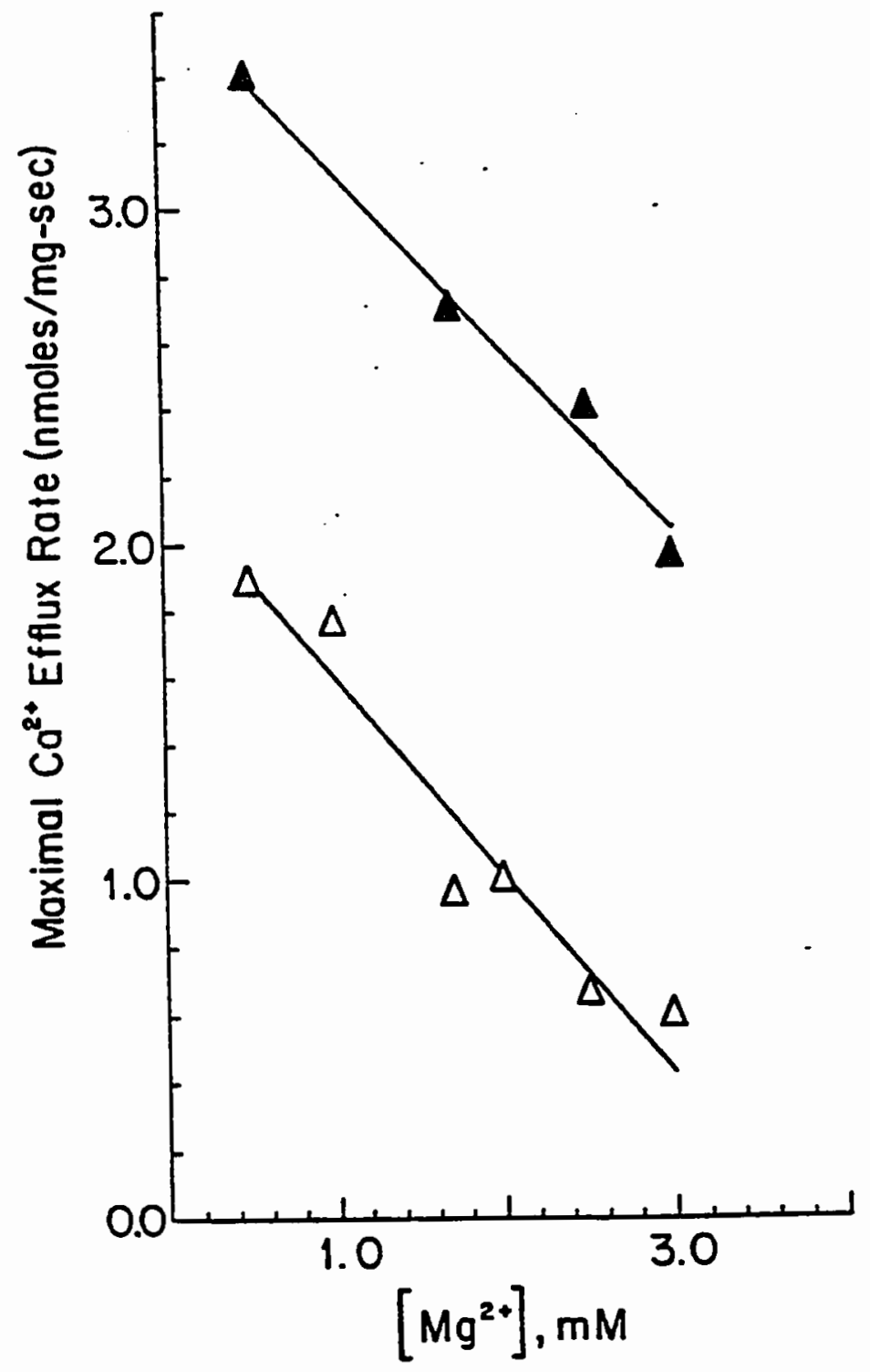

Figure 5. Magnesium dependence of oxidationinduced $\mathrm{Ca}^{2+}$ efflux. SR vesicles. were incubated overnight as described in Figure 4 except the $\mathrm{Mg}^{2+}$ concentration was varied from 0.5 to $3.0 \mathrm{mM}$. Vesicles were diluted into effluxing buffer containing the same $\mathrm{Mg}^{2+}$ concentration. The final protein concentration was $0.2 \mathrm{mg} / \mathrm{mL}$. Efflux was initiated by the addition of $(\Delta) 2$ $\mu \mathrm{M} \mathrm{Cu}{ }^{2+}$ or $(\Delta) 2 \mu \mathrm{M} \mathrm{Cu}^{2+}$ plus $0.5 \mathrm{mM} \mathrm{Mg} \mathrm{Mg}^{2+}$ AMPPCP. 
efflux rate in $\mathrm{nmol} / \mathrm{mg}-\mathrm{sec}$ by the total $\mathrm{Ca}^{2+}$ effluxed), the rate constant $\left(s^{-1}\right)$, within experimental error, is independent of the $\mathrm{Mg}^{2+}$ gradient (Figure 6B). (Note: under these experimental conditions the $\mathrm{Ca}^{2+}$ efflux does not follow true first-order kinetics but mixed order.) Changing the internal $\mathrm{Mg}^{2+}$ concentration does not affect the rate constant for $\mathrm{Ca}^{2+}$ efflux stimulated by $\mathrm{Cu}^{2+} /$ cysteine and adenine nucleotides.

All of the measurements presented were made using the $\mathrm{Ca}^{2+}$ indicator dye, AsIII. To verify these results, vesicles were actively loaded with $10 \mu \mathrm{M} \mathrm{Ca}{ }^{2+}$ using acetyl phosphate and $\mathrm{Ca}^{2+}$ efflux was followed using a $\mathrm{Ca}^{2+}$ selective electrode. The experimental protocol was the same as that described in Figure 3, but in the absence of AsIII. Figure 7, trace 5, shows that under these conditions AMP-PCP induces a slow efflux of $\mathrm{Ca}^{2+}$ (less than $0.2 \mathrm{nmol} / \mathrm{mg}-\mathrm{sec}) . \quad$ In Figure 7 , adenine nucleotide stimulation of $\mathrm{Cu}^{2+} /$ cysteine-induced $\mathrm{Ca}^{2+}$ efflux is shown to be qualitatively the same as seen with AsIII present (Figure 3). The adenine nucleotides tested show the same relative effectiveness in stimulating $\mathrm{Ca}^{2+}$ efflux; however, the $\mathrm{Ca}^{2+}$ efflux rates measured with the electrode are 3-4 times larger than those measured using AsIII. Also, unlike the spectrophotometric measurements, the electrode measurements indicate that the percentage of $\mathrm{Ca}^{2+}$ effluxed is not affected by the presence or absence of nucleotides. 


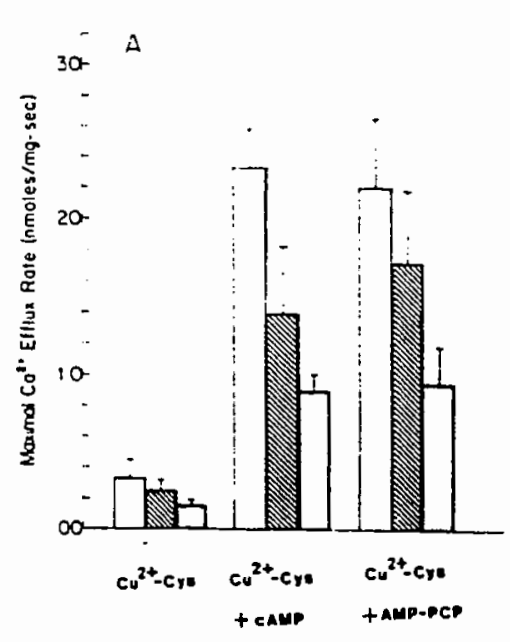

Effluxing Reagent

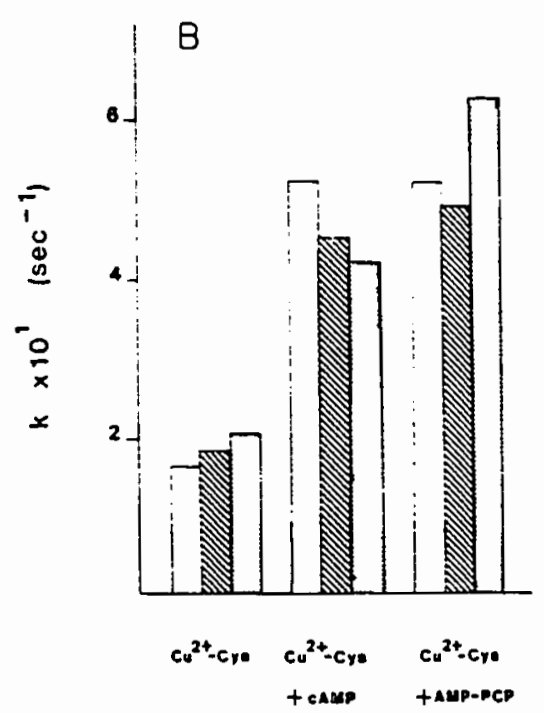

Effluxing Reagent

Figure 6. Effect of internal $\mathrm{Mg}^{2+}$ concentration on $\mathrm{Ca}^{2+}$ efflux from passively loaded SR vesicles. $S R$ vesicles were passively loaded as described in Figure 4 in a buffer containing 0 ( $\square$ ), 3 ( खणी ) or 30 ( $\square$ ) $\mathrm{mM} \mathrm{Mg}{ }^{2+}$. Vesicles were diluted into effluxing buffer containing $10 \mu \mathrm{M}$ cysteine, $100 \mu \mathrm{M}$ AsIII and $3 \mathrm{mM} \mathrm{Mg}^{2+}$. The final protein concentration was $0.2 \mathrm{mg} / \mathrm{mL}$. $\mathrm{Cu}^{2+}(2 \mu \mathrm{M})$ or $2 \mu \mathrm{M}$ $\mathrm{Cu}^{2+}$ plus either $0.5 \mathrm{mM}$ CAMP or $0.5 \mathrm{mM} \mathrm{Mg} \mathrm{Mg}^{2+}$ AMPPCP were added to induce $\mathrm{Ca}^{2+}$ efflux. (A) The efflux rate as a function of internal $\mathrm{Mg}^{2+}$ concentration. (B) The data are normalized with respect to total $\mathrm{Ca}^{2+}$ released and expressed as a rate constant. The error bars on the graph show the standard deviations $(n=3)$. 
The indicator dye, AsIII, appears to be inhibiting $\mathrm{Cu}^{2+} /$ cysteine-induced $\mathrm{Ca}^{2+}$ efflux. The presence of AsIII also decreases the percentage of $\mathrm{Ca}^{2+}$ released by the addition of $\mathrm{Cu}^{2+} /$ cysteine. To confirm this apparent inhibition by AsIII, $\mathrm{Ca}^{2+}$ efflux rates stimulated by $\mathrm{Cu}^{2+} /$ cysteine were measured using ${ }^{45} \mathrm{Ca}^{2+}$ and established millipore filtration techniques (110). Under these experimental conditions AsIII inhibits oxidation-induced efflux by greater than 20\%. When comparing spectrophotometric measurements with AsIII and $\mathrm{Ca}^{2+}$ efflux rates using the $\mathrm{Ca}^{2+}$ electrode, a somewhat larger inhibition by AsIII was observed (Table III).

It has been suggested that AsIII may be inhibiting oxidation-induced efflux by acting as a superoxide radical scavenger. Efflux rates were measured (using the $\mathrm{Ca}^{2+}$ selective electrode) in the presence and absence of 0.2 $\mathrm{mg} / \mathrm{mL}$ superoxide dismutase (SOD) to test this hypothesis. The oxidation-induced efflux rates in the absence and presence of SOD were $1.7 \pm 0.5$ and $1.8 \pm 0.4 \mathrm{nmol} / \mathrm{mg}-\mathrm{sec}$, respectively. This indicates that the production of superoxide radicals does not play a role in the increased rates observed in the absence of AsIII. AsIII alters free cation concentrations which may affect the oxidationinduced efflux rates. The inhibition of a $\mathrm{Ca}^{2+}$-gated cation channel from $S R$ by AsIII has been previously reported (111). 


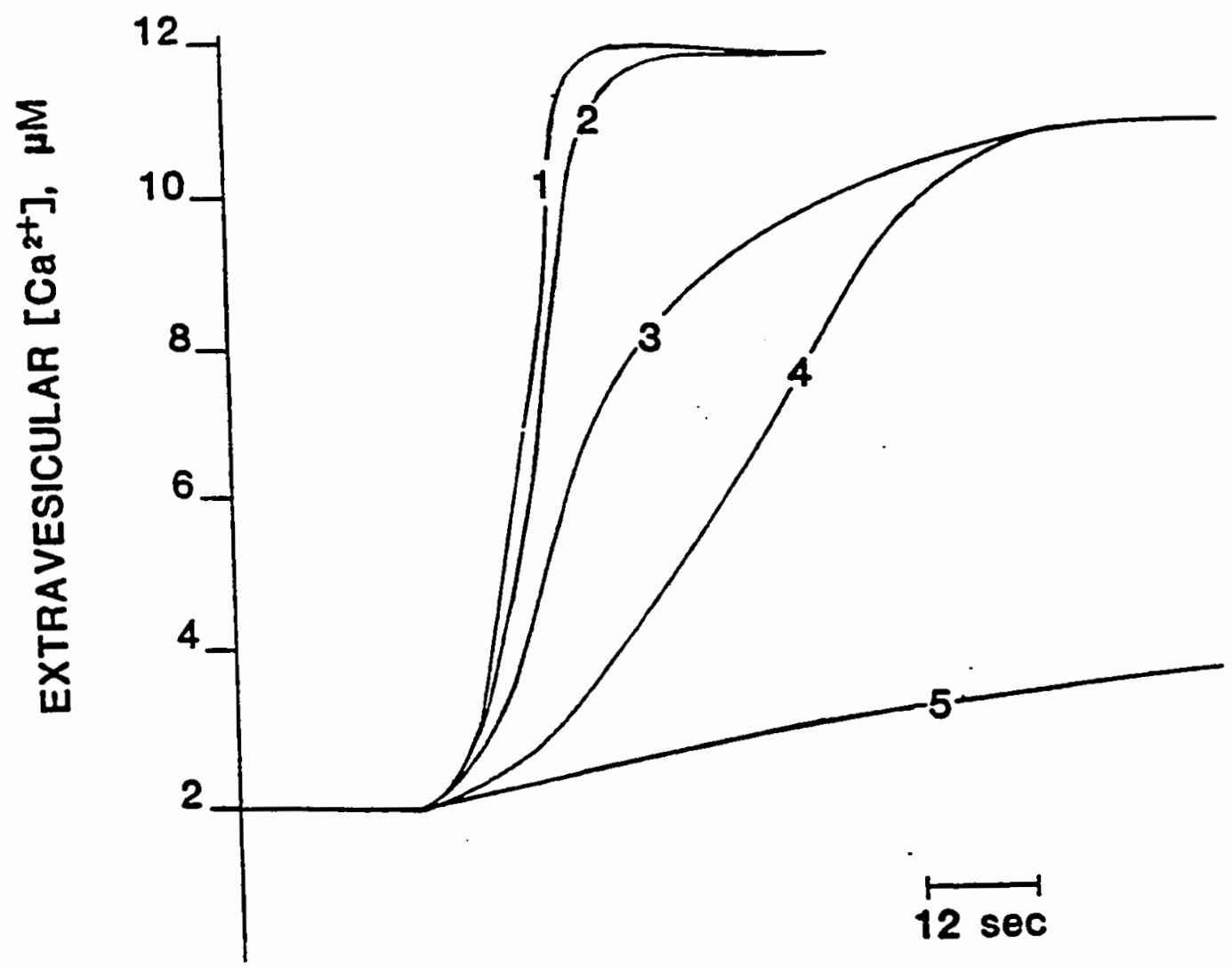

TIME, sec

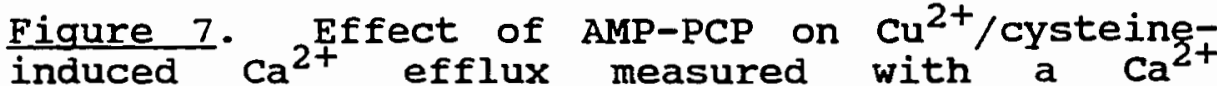
selective electrode. SR vesicles were diluted into uptake buffer (see Figure 3) to a final protein concentration of $0.18 \mathrm{mg} / \mathrm{mL}$ in the presence of $10 \mathrm{mM}$ cysteine. After addition of $20 \mu \mathrm{M} \mathrm{Ca}{ }^{2+}$, uptake was initiated by the addition of $1.0 \mathrm{mM} \mathrm{AcPO} 4$. After accumulation of the added $\mathrm{Ca}^{2+}$, effflux was initiated by the addition of (1) $4 \mu \mathrm{M} \mathrm{Cu}{ }^{2+}+0.5 \mathrm{mM} \mathrm{Mg}{ }^{2+} \mathrm{AMP}-\mathrm{PCP} ;$ (2) $4 \mu \mathrm{M} \mathrm{Cu}^{2+}+$ $0.5 \mathrm{mM}$ CAMP; (3) $4 \mu \mathrm{M} \mathrm{C} \mathrm{u}^{2+}+0.5 \mathrm{mM} \mathrm{AMP;} \mathrm{(4)} 4 \mu \mathrm{M}$ $\mathrm{Cu}^{2+}$; or (5) $0.5 \mathrm{mM} \mathrm{Mg}{ }^{2+}$ AMP-PCP. Maximal efflux rates in nmol/mg-sec are (1) 8.8, (2), 7.9 (3) 3.8 , (4) 1.3 , and (5) 0.2 . 
TABLE III

EFFECT OF ASIII ON OXIDATION AND ADENINE NUCLEOTIDE STIMULATION OF OXIDATION-INDUCED CALCIUM EFFLUX FROM ACTIVELY LOADED VESICLES

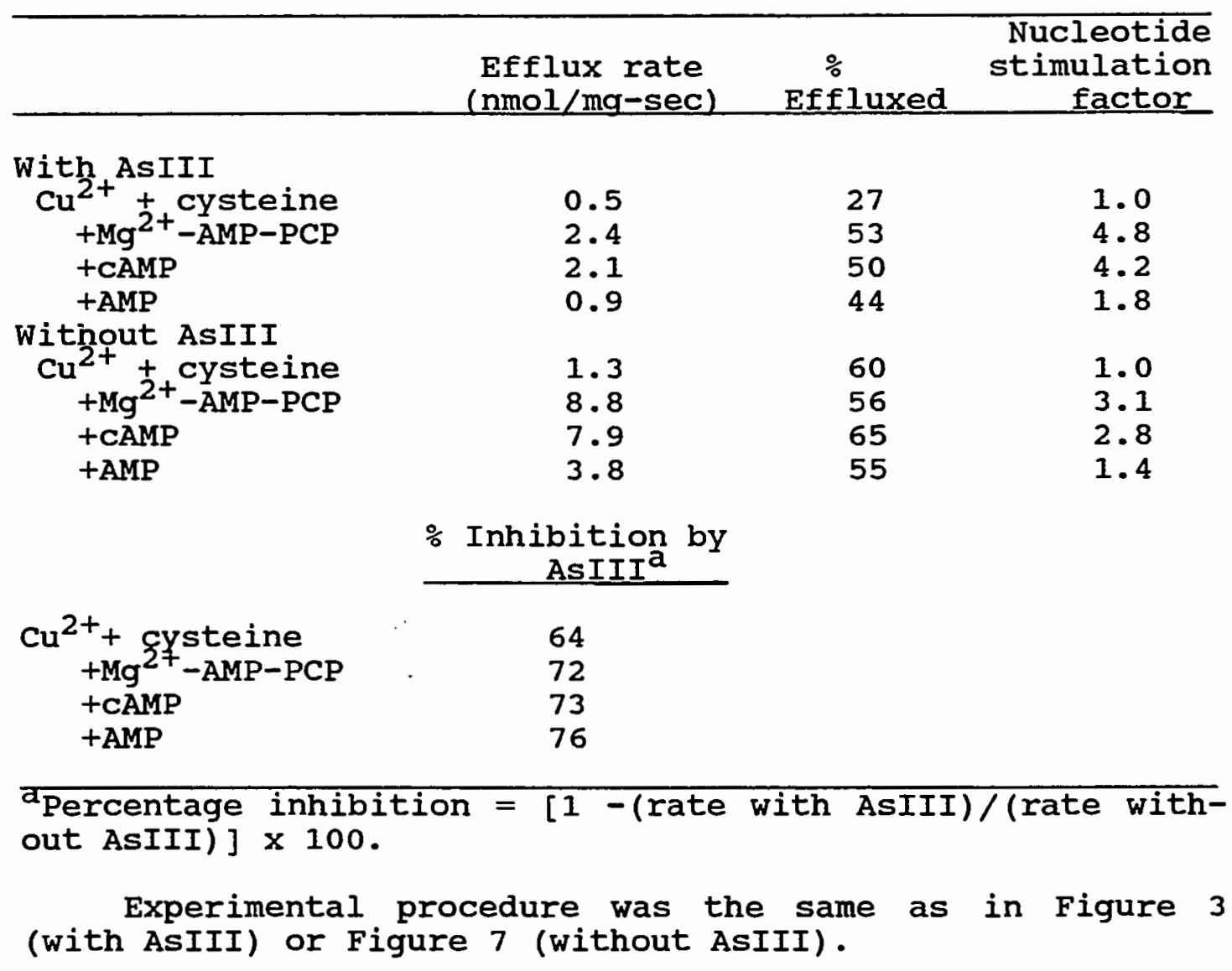


DISCUSSION

By monitoring $\mathrm{Ca}^{2+}$ flux across the SR using either the $\mathrm{Ca}^{2+}$ indicator dye, AsIII, or a $\mathrm{Ca}^{2+}$-selective electrode, it has been shown that various adenine containing nucleotides synergistically stimulate $\mathrm{Cu}^{2+} /$ cysteine (oxidation)-induced $\mathrm{Ca}^{2+}$ efflux from $\mathrm{SR}$ vesicles. If $\mathrm{Ca}^{2+}$ is actively taken up by the SR, using acetyl phosphate as substrate for the pump, efflux induced by the addition of $\mathrm{Cu}^{2+} /$ cysteine is enhanced by the following nucleotides (listed in the order of effectiveness):

$$
\text { ATP }>\text { AMP-PCP }>\text { CAMP }>\text { AMP }>\text { adenine. }
$$

The order of effectiveness is the same as that observed by Meissner in stimulating $\mathrm{Ca}^{2+}$-induced $\mathrm{Ca}^{2+}$ efflux from SR vesicles (68, 112). Morii and Tonomura (58) also measured nucleotide stimulation of $\mathrm{Ca}^{2+}$-induced $\mathrm{Ca}^{2+}$ efflux, but they observed a different relative effectiveness of the nucleotides tested. This discrepancy may be due to different experimental conditions. Morii and Tonomura (58) carried out their experiments at $0^{\circ} \mathrm{C}$ and at $5 \mathrm{mM} \mathrm{MgCl}_{2}$. The experiments reported here were performed at $23^{\circ} \mathrm{C}$ and at $3 \mathrm{mM} \mathrm{MgCl}_{2}$.

of the nucleotides added to stimulate $\mathrm{Cu}^{2+} /$ cysteineinduced $\mathrm{Ca}^{2+}$ efflux, AMP-PCP, the nonhydrolyzable analog of ATP, was the second most effective. Under our experimental conditions ( $3 \mathrm{mM} \mathrm{Mg}^{2+}, \mathrm{pH} 6.8$ ), $\mathrm{Ca}^{2+}$ efflux stimulated by AMP-PCP (in the absence of $\mathrm{Cu}^{2+} /$ cysteine) is slow. AMP-PCP 
$(0.5 \mathrm{mM})$ causes $-60 \%$ efflux of internal $\mathrm{Ca}^{2+}$ at a rate of less than $0.2 \mathrm{nmol} \mathrm{ca}^{2+} / \mathrm{mg}-\mathrm{sec}$. The nucleotide is relatively ineffective in causing $\mathrm{Ca}^{2+}$ release from the SR vesicles but is very effective in stimulating $\mathrm{Cu}^{2+} /$ cysteine-induced $\mathrm{Ca}^{2+}$ efflux. As seen in Figure 5, independent of the external $\mathrm{Mg}^{2+}$ concentration, AMP-PCP increases $\mathrm{Cu}^{2+} /$ cysteine-induced $\mathrm{Ca}^{2+}$ efflux rates by a fixed amount. Although $\mathrm{Cu}^{2+} /$ cysteine-induced $\mathrm{Ca}^{2+}$ efflux is strongly $\mathrm{Mg}^{2+}$ dependent (Figure 5), the enhancement by the addition of $0.5 \mathrm{mM}$ nucleotide is $\mathrm{Mg}^{2+}$ independent. Upon addition of $\mathrm{Cu}^{2+}$ and cysteine to the SR vesicles, the $\mathrm{Ca}^{2+}$ release protein has been covalently modified by oxidation of an exogenous cysteine to a critical sulfhydryl group (22). The binding of the adenine nucleotide may be increasing the number of sulfhydryl groups accessible to oxidation independent of the $\mathrm{Mg}^{2+}$ concentration.

AMP-PCP stimulation of $\mathrm{Cu}^{2+} /$ cysteine-induced $\mathrm{Ca}^{2+}$ efflux shows saturation kinetics with a $k_{M}$ of approximately $0.14 \mathrm{mM}$ (Figure 4) and a Hill coefficient of 1 (not shown). The binding affinity for AMP-PCP is lower than Meissner reports (68) and higher than that measured for AMP by Morii and Tonomura (58). This discrepancy may be due to different $\mathrm{Mg}^{2+}$ concentrations present during the efflux measurements. Meissner used a free $\mathrm{Mg}^{2+}$ concentration of $0.6 \mathrm{mM}$ (68) while Morii and Tonomura (58) used $5 \mathrm{mM} \mathrm{Mg}^{2+}$. In this study the free $\mathrm{Mg}^{2+}$ was $3 \mathrm{mM}$. 
Because the stimulatory effect of the adenine nucleotides on oxidation-induced $\mathrm{Ca}^{2+}$ efflux is synergistic (more than additive), the reactive sites (reactive $-\mathrm{SH}$ and nucleotide binding site) are likely to be located on the same protein or on closely associated proteins. As shown in Figure 7 , the $\mathrm{Ca}^{2+}$ efflux rate with $\mathrm{Cu}^{2+} /$ cysteine alone is $1.3 \mathrm{nmol} / \mathrm{mg}-\mathrm{sec}$, with $\mathrm{Mg}^{2+}-\mathrm{AMP}-\mathrm{PCP}$ alone it is 0.2 $\mathrm{nmol} / \mathrm{mg}-\mathrm{sec}$. However, when the two reagents are added together the $\mathrm{Ca}^{2+}$ efflux rate is $8.8 \mathrm{nmol} / \mathrm{mg}-\mathrm{sec}$. The additive rate would have been $1.5 \mathrm{nmol} / \mathrm{mg}-\mathrm{sec}$; however, the determined rate was approximately $6 x$ larger. This synergistic stimulation indicates that the interaction of the AMP-PCP with the SR somehow facilitates the oxidation reaction or that $-\mathrm{SH}$ oxidation stimulates AMP-PCP-induced $\mathrm{Ca}^{2+}$ release. This may be accomplished by a secondary conformational change of the release protein upon the binding of AMP-PCP thereby possibly increasing exposure of critical sulfhydryls. Arrondo et al. (113) have reported that the binding of ATP to SR vesicles induces a secondary conformational change in the SR proteins by increasing $\alpha-$ helical and $\beta$-antiparallel structures.

Nagasaki and Kasai (57) and Smith et al. (109) have shown that $\mathrm{Mg}^{2+}$ can permeate through the $\mathrm{Ca}^{2+}$-induced $\mathrm{Ca}^{2+}$ release channel. In Figure 6 , we examined the effect of a $\mathrm{Mg}^{2+}$ gradient on the $\mathrm{Ca}^{2+}$ efflux rate triggered by $\mathrm{Cu}^{2+} /$ cysteine and adenine nucleotides. When the data are 
corrected for unequal $\mathrm{Ca}^{2+}$ loading at different internal $\mathrm{Mg}^{2+}$ concentrations, the $\mathrm{Ca}^{2+}$ efflux rate constant $\left(\mathrm{s}^{-1}\right)$, within experimental error, is independent of the internal $\mathrm{Mg}^{2+}$ concentration. If $\mathrm{Ca}^{2+}$ and $\mathrm{Mg}^{2+}$ are effluxing through the same channel, a competition between the two divalent cations (i.e., as the outwardly directed $\mathrm{Mg}^{2+}$ gradient increased, the efflux rate of $\mathrm{Ca}^{2+}$ would decrease) would be expected. A possible explanation for this apparent discrepancy is that the $\mathrm{Ca}^{2+}$ release channel is far from being saturated with either $\mathrm{Mg}^{2+}$ or $\mathrm{Ca}^{2+}$ under the conditions of these experiments.

It has been previously shown that addition of micromolar concentrations of $\mathrm{Cu}^{2+}$ and cysteine leads to rapid efflux of $\mathrm{Ca}^{2+}$ from $\mathrm{SR}$ vesicles (22). The data presented here suggest that the binding of ATP, by itself, is sufficient to synergistically enhance oxidation and heavy metal-induced $\mathrm{Ca}^{2+}$ efflux from SR vesicles. This is supported by the fact that AMP-PCP, a nonhydrolyzable analog of ATP, is almost as effective as ATP at stimulating oxidation-induced $\mathrm{Ca}^{2+}$ efflux. Since AMP-PCP does not dissociate at the $\beta-\gamma$ phosphate bond, the hydrolysis of this bond cannot be essential in the stimulation effect. Nevertheless, ATP is more effective in stimulating oxidation-induced $\mathrm{Ca}^{2+}$ efflux than AMP-PCP. The lower effectiveness of AMP-PCP might be due to slight differences in molecular configurations between the two molecules. An 
alternate possibility is that the stimulatory effect is initiated by the binding of the nucleotide to a specific site and is further enhanced by the hydrolysis of a phosphate bond.

The similarities between $\mathrm{Ca}^{2+}$-induced $\mathrm{Ca}^{2+}$ release and oxidation-induced release are striking. It appears as if the critical sulfhydryl group, which can either bind heavy metals $(110,114)$ or be oxidized (22) to trigger $\mathrm{Ca}^{2+}$ release, must be in close proximity to the, as yet undefined, $\mathrm{Ca}^{2+}$ binding site responsible for triggering $\mathrm{Ca}^{2+}$-induced $\mathrm{Ca}^{2+}$ release. An alternative explanation for the similarity between these two methods of triggering $\mathrm{Ca}^{2+}$ release is that the underlying molecular mechanism behind both methods of triggering release are the same. Perhaps $\mathrm{Ca}^{2+}$ binding is the first of a series of steps that results in the oxidation of a sulfhydryl group to a disulfide. 


\section{CHAPTER IV}

\section{PHOTOOXIDATION OF SARCOPLASMIC RETICULUM VESICLES}

\section{SUMMARY}

Treatment of sarcoplasmic reticulum (SR) vesicles with the photooxidizing dye, rose bengal, increases the permeability of the vesicles to $\mathrm{Ca}^{2+}$ Vesicles actively loaded with $\mathrm{Ca}^{2+}$, using acetyl phosphate as pump substrate, rapidly release accumulated $\mathrm{Ca}^{2+}$ when irradiated in the presence of $3 \mu \mathrm{M}$ rose bengal. Ruthenium red or ATP in the reaction buffer inhibits the release induced by rose bengal. The maximal $\mathrm{Ca}^{2+}$ efflux rate is $\mathrm{Mg}^{2+}$ independent; however, $\mathrm{Mg}^{2+}$ increases an initial lag phase preceding $\mathrm{Ca}^{2+}$ release. At a rose bengal concentration of $0.1 \mu \mathrm{M}, \mathrm{Ca}^{2+}$, $\mathrm{Mg}^{2+}$-ATPase activity is less than 50\% inhibited after 1 minute of exposure, yet all of the $\mathrm{Ca}^{2+}$ has exited from the vesicles with less than 30 seconds of exposure. Heavy SR is $40 \%$ more sensitive to rose bengal than longitudinal SR.

\section{INTRODUCTION}

Investigators for many years have used photosensitive dyes to selectively oxidize amino acid residues in proteins (8-90, 115-122). Rose bengal and methylene blue are two such dyes used to oxidize histidyl residues (101). The 
effect of photooxidation on the $\mathrm{Ca}^{2+}$ permeability of skeletal muscle sarcoplasmic reticulum (SR) is reported in the present chapter.

The SR is an internal membrane system within muscle cells. It controls the myoplasmic $\mathrm{Ca}^{2+}$ concentration thereby regulating contraction and relaxation of skeletal muscle (10). Myoplasmic $\mathrm{Ca}^{2+}$ is accumulated into the SR by the $\mathrm{Ca}^{2+}, \mathrm{Mg}^{2+}$-ATPase. The ATPase has been extensively studied; however, the mechanism by which $\mathrm{Ca}^{2+}$ is released is less well understood.

Several theories have been proposed to describe the link between the depolarization of the transverse tubules and the rapid release of $\mathrm{Ca}^{2+}$ from the SR. The most extensively studied of these theories is $\mathrm{Ca}^{2+}$ induced $\mathrm{Ca}^{2+}$ release (10). $\mathrm{Ca}^{2+}$-induced $\mathrm{Ca}^{2+}$ release is modulated by the extravesicular $\mathrm{Ca}^{2+}$ concentration (57) and it is stimulated by adenine nucleotides $(57,63,68,70,123)$ and caffeine $(62,107,123)$. It is inhibited by local anaesthetics $(62,123)$, ruthenium red $(41,54)$ and $\mathrm{Mg}^{2+}$ $(41,57,62)$. In spite of a large number of studies describing $\mathrm{Ca}^{2+}$-induced $\mathrm{Ca}^{2+}$ release, no chemical description of the $\mathrm{Ca}^{2+}$ binding site exists.

Chemical modification of the SR has also been reported to cause rapid release of $\mathrm{Ca}^{2+}$ from the $\mathrm{SR}$ vesicles (22, $79,82,83,86,114,124-126)$. Oxidation of a reactive thiol induces rapid $\mathrm{Ca}^{2+}$ release from the $\operatorname{SR}(22,82,83$, 
114, 124-126). Oxidation-induced $\mathrm{Ca}^{2+}$ release is stimulated by adenine nucleotides $(81,82,83,124$,$) , and$ inhibited by ruthenium red $(22,82,83,124-125)$, local anaesthetics (22) and $\mathrm{Mg}^{2+}(22,82,83,114,124-126)$. Modification of amino groups has also been shown to stimulate $\mathrm{Ca}^{2+}$ release from passively loaded vesicles ( 86 , 126). Modification of 1 mole lysine and 1-2 mole histidine (87) per mole ATPase have been reported to decrease $\mathrm{Ca}^{2+}$, $\mathrm{Mg}^{2+}$-ATPase activity and uncouple active $\mathrm{Ca}^{2+}$ transport. Photooxidation of SR proteins results in an inhibition of ATPase activity and an uncoupling of $\mathrm{Ca}^{2+}$ transport (8890, 120-121). This effect has been reported to be due to the oxidation of histidyl residues (88-90) or tryptophanyl residues $(90)$.

In the present study, it is reported that photooxidation of the $S R$, using rose bengal as the sensitizer, results in rapid release of accumulated $\mathrm{Ca}^{2+}$. ATP protects the SR from modification. The effect is partially inhibited by ruthenium red and is $\mathrm{Mg}^{2+}$ and $\mathrm{Ca}^{2+}$ independent.

\section{RESULTS}

Figure 8 shows the decrease in ATPase activity and $\mathrm{Ca}^{2+}$ uptake as a function of rose bengal concentration. It is of interest to note that the uptake activity is more sensitive to rose bengal than the ATPase activity. This is 

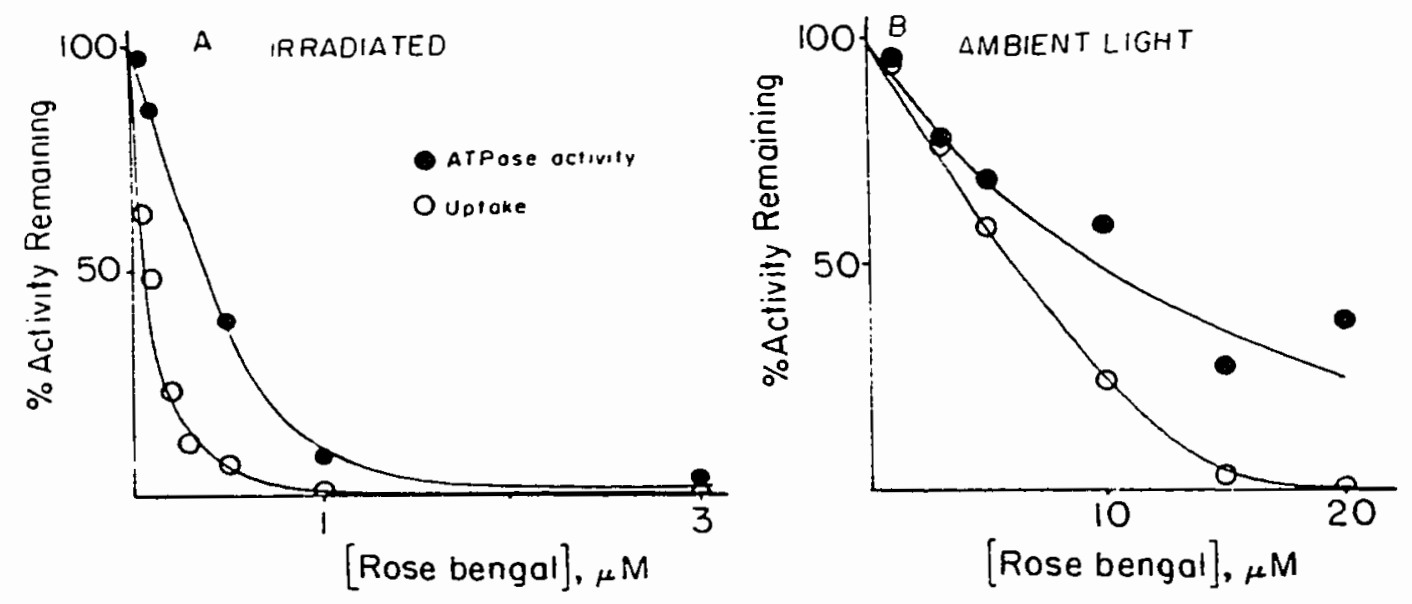

Figure 8. $\mathrm{Ca}^{2+}$ uptake and ATPase activity as a function of rose bengal. SR vesicles were diluted into a buffer containing $100 \mathrm{mM} \mathrm{KCl}, 1 \mathrm{mM}$ $\mathrm{MgCl}_{2}, 20 \mu \mathrm{M} \mathrm{CaCl} 2$ and $50 \mathrm{mM}$ Hepes, $\mathrm{pH} 7.0$ to a final protein concentration of $0.2 \mathrm{mg} / \mathrm{mL}$. The indicated concentration of rose bengal was added and the vesicles were incubated for 1 minute in ambient light (Figure $8 \mathrm{~b}$ ) or irradiated with a 360-watt, broad spectrum light source (Figure 8a). The treated SR vesicles were diluted into an ATPase (O) reaction buffer containing $150 \mathrm{mM}$ $\mathrm{KCl}, 75 \mathrm{mM}$ Hepes, $\mathrm{pH} 7.0,1.5 \mathrm{mM} \mathrm{MgCl}, 10 \mathrm{mg} / \mathrm{mL}$ PEP, $10 \mathrm{mg} / \mathrm{mL}$ PK, $27 \mathrm{mg} / \mathrm{mL} \mathrm{LDH}, \sim 0.4 \mathrm{mg} / \mathrm{mL}$ NADH and $-2 \mu \mathrm{M}$ A23187 to a final protein concentration of $0.018 \mathrm{mg} / \mathrm{mL}$. $1.8 \mathrm{mM}$ ATP was added to start the reaction. The decrease of the absorbance at $340 \mathrm{~nm}$ was followed as a function of time. The \% ATPase activity remaining was calculated by normalizing the ATPase activity of the SR without the addition of rose bengal to be $100 \%$ activity. This represents a $\mathrm{Ca}^{2+}$ dependent ATPase activity of $3.35 \pm 0.10 \mu$ moles $/ \mathrm{mg}$-min. Ca2t uptake ( $O$ ) was determined using APIII. $1 \mathrm{mM} \mathrm{Mg}^{2+}-\mathrm{ATP}$ was added to $1.5 \mathrm{~mL}$ of treated vesicles to initiated calcium uptake. The percentage uptake was determined by dividing the amount of uptake in treated vesicles by the amount of uptake in untreated vesicles. 
consistent with previously reported data (88-90, 120-121). $\mathrm{Ca}^{2+}$ uptake shows a half maximal inhibition $\left(\mathrm{IC}_{50}\right)$ at 0.1 $\mu \mathrm{M}$ for the light reaction $(6.5 \mu \mathrm{M}$ for the dark reaction while ATPase activity has an $I_{50}$ of $\sim 0.5 \mu \mathrm{M}$ for the light reaction (11 $\mu \mathrm{M}$ for the dark reaction). The decrease in uptake prior to decrease of ATPase activity could be a result of an uncoupling of transport from ATPase activity or it could be due to an increase in the $\mathrm{Ca}^{2+}$ permeability of SR vesicles. In this report, the effects of photooxidation on the $\mathrm{Ca}^{2+}$ efflux properties of isolated skeletal SR vesicles are examined.

At low concentrations (less than $3 \mu \mathrm{M}$ ) rose bengal causes rapid $\mathrm{Ca}^{2+}$ efflux from actively loaded SR vesicles when irradiated with a 360-watt, broad-spectrum light source. At concentrations of $5 \mu \mathrm{M}$ or greater, rose bengal causes rapid release of $\mathrm{Ca}^{2+}$ without direct irradiation (see Figure 9). The experiments using high concentrations of rose bengal were carried out under semi-dark conditions (see methods for further description). Experiments performed in the presence of ambient fluorescent light gave the same results as experiment performed in the semi-dark. There is a rapid release of approximately $80 \%$ of the internal $\mathrm{Ca}^{2+}$ with a slower release of the remaining $20 \%$. Figures $10 \mathrm{a}$ and $\mathrm{10b}$ show the $\mathrm{Ca}^{2+}$ efflux rate as a function of the rose bengal concentration. At concentrations higher than $50 \mu \mathrm{M}$, rose bengal binds $\mathrm{Ca}^{2+}$ in a non-specific 


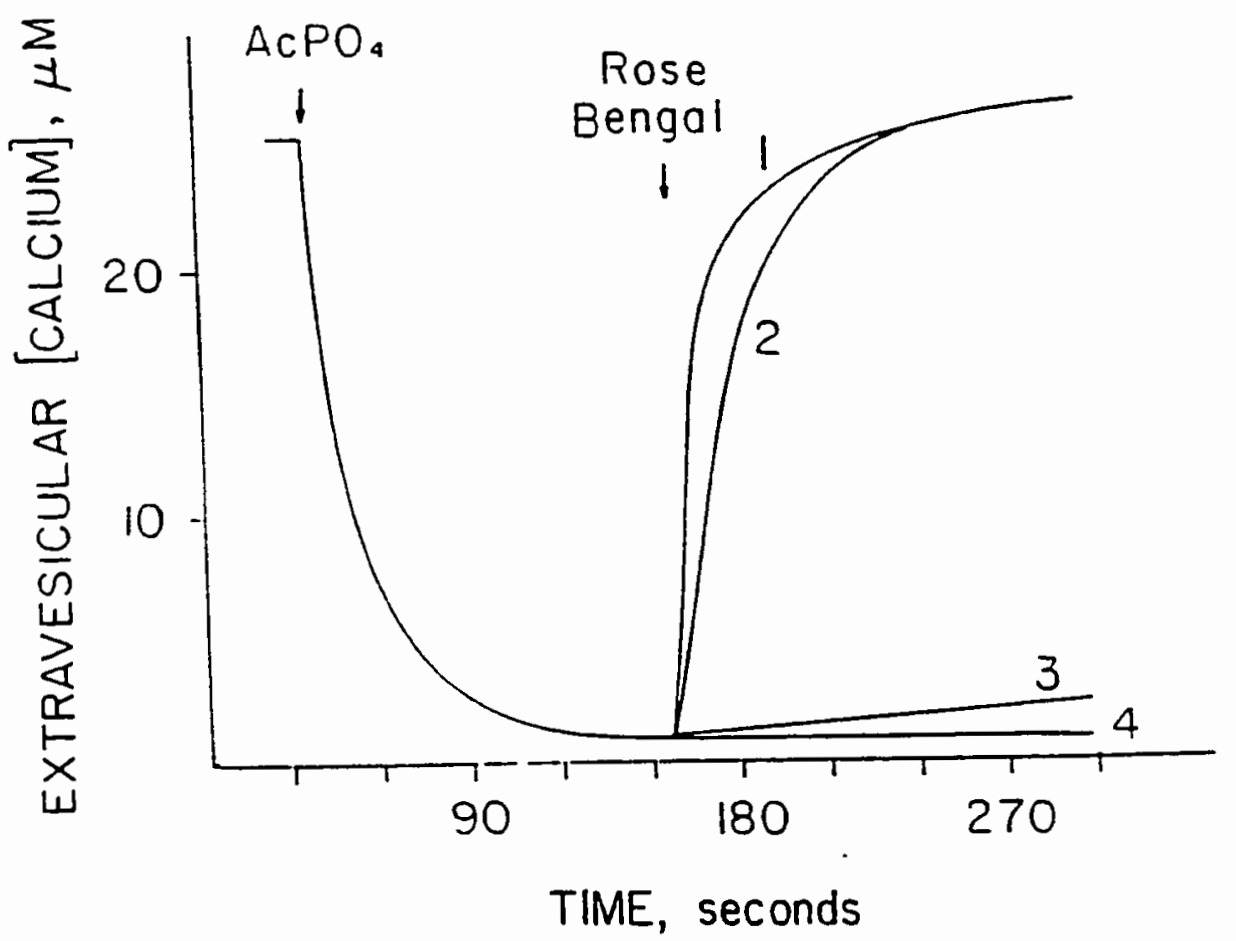

Fiqure 9. Rose bengal-induced $\mathrm{Ca}^{2+}$ efflux from actively loaded $S R$ vesicles. $S R$ vesicles were diluted into uptake buffer $(100 \mathrm{mM} \mathrm{KCl}, 3 \mathrm{mM}$ $\mathrm{MgCl}_{2}, 50 \mathrm{mM}$ Hepes, $\mathrm{pH} \mathrm{7.0)}$ to a final protein concentration of $0.2 \mathrm{mg} / \mathrm{mL}$. One aliquot of $20 \mu \mathrm{M}$ $\mathrm{Ca}^{2+}$ was added and uptake was initiated by the addition of $2.0 \mathrm{mM} \mathrm{AcPO}{ }_{4}$. After accumulation of the added $\mathrm{Ca}^{2+}$, efflux was initiated by the addition of either (1) $5 \mu \mathrm{M}$ rose bengal in the semi-dark or (2) $1 \mu \mathrm{M}$ rose bengal plus irradiation from a 360-watt light source at a distance of $30 \mathrm{~cm}$. As a control, (3) $1 \mu \mathrm{M}$ rose bengal was added in the semi-dark; (4) represents the baseline if no effluxing reagent is added. 
fashion and forms a multi-molecular aggregate (127), therefore high concentrations of rose bengal were avoided. Ruthenium red is known to inhibit $\mathrm{Ca}^{2+}$-induced $\mathrm{Ca}^{2+}$ release $(41,54)$ and oxidation-induced $\mathrm{Ca}^{2+}$ release (22, $82,83,114,125-126)$. It is likely that this inhibition is accomplished by binding of the ruthenium red to the release channel and sterically blocking the release channel. As shown in Table IV, rose bengal-induced $\mathrm{Ca}^{2+}$ efflux is inhibited by micromolar concentration of ruthenium red. The ruthenium red must be present in the reaction buffer to inhibit rose bengal-induced $\mathrm{Ca}^{2+}$ efflux. If ruthenium red is added after the rose bengal, no inhibition or blockage of $\mathrm{Ca}^{2+}$ efflux is observed. This suggests that ruthenium red blocks rose bengal interaction with the $\mathrm{Ca}^{2+}$ transport system in the $\mathrm{SR}$ or it somehow interferes with the photooxidation reaction. The rate of $\mathrm{Ca}^{2+}$ efflux in the presence of $10 \mu \mathrm{M}$ ruthenium red in the reaction buffer is slowed by $\sim 60 \%$ in the semi-dark reaction and $-88 \%$ in the light reaction. However, the total percentage of $\mathrm{Ca}^{2+}$ release is not reduced by ruthenium red.

The ruthenium red may be preventing rose bengal from being photo-reactive thereby preventing the production of singlet oxygen. The $\lambda_{\max }$ of rose bengal $=549 \mathrm{~nm}$, the $\lambda_{\max }$ of ruthenium red $=535 \mathrm{~nm}$. When $1 \mu \mathrm{M}$ rose bengal is mixed with $1 \mu \mathrm{M}$ ruthenium red a complex is formed with a $\lambda_{\max }$ of $526 \mathrm{~nm}$. Methylene blue, a cationic non-binding 


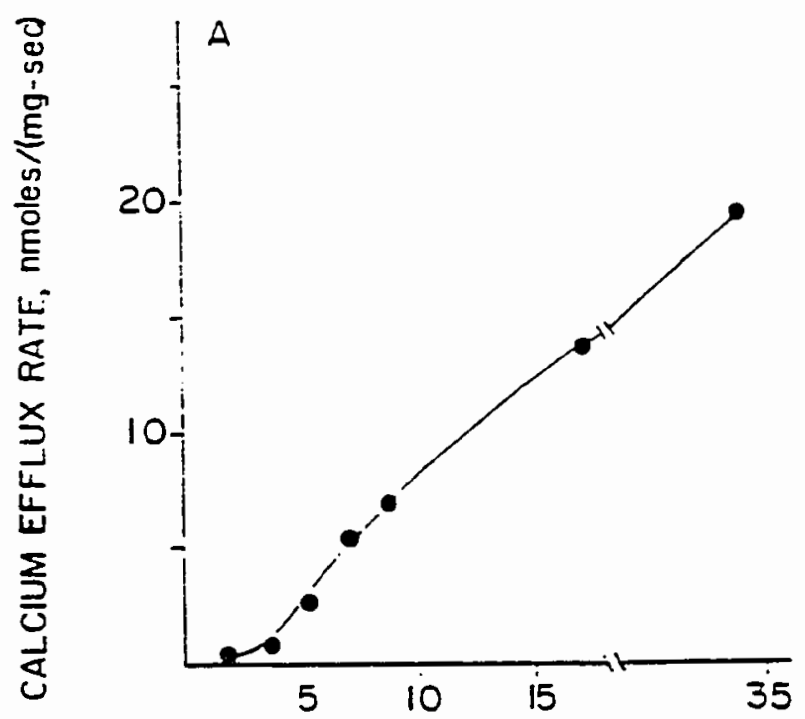

[ROSE BENGAL', $\mu M$

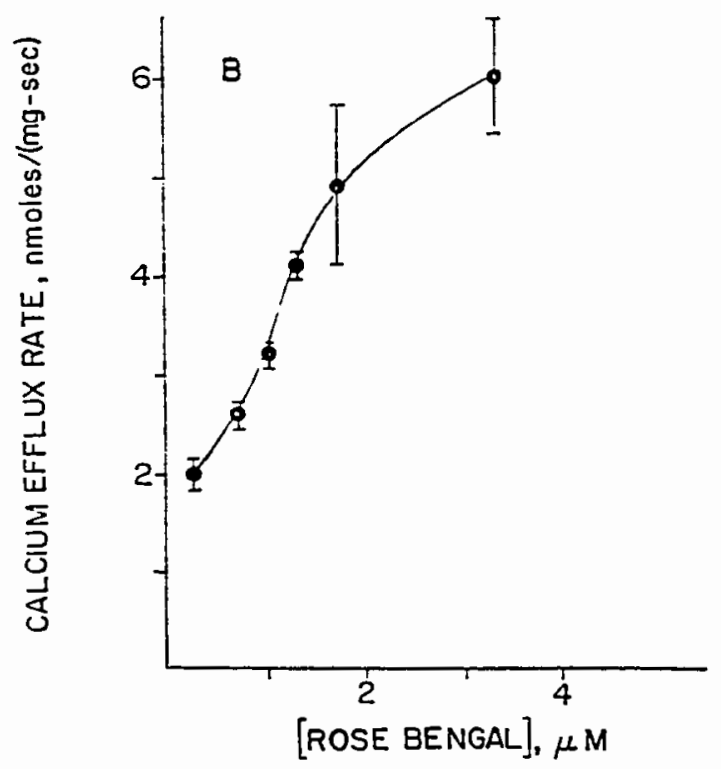

Figure 10. Concentration dependence of rose bengal-induced $\mathrm{Ca}^{2+}$ efflux. SR vesicles were actively loaded as described in Figure 9. After accumulation of $\mathrm{Ca}^{2+}$, efflux was initiated by the addition of various concentrations of rose bengal in the semi-dark (10a) or with the addition of irradiation as described in Figure 9 (10b). Figure $10 a$ shows data from a representative experiment. Figure $10 \mathrm{~b}$ shows the mean and standard deviation for data points run in triplicate. 
TABLE IV

COMPARISON OF THE EFFECT OF VARIOUS REAGENTS ON CALCIUM EFFLUX RATES FROM ROSE BENGAL TREATED VESICLES

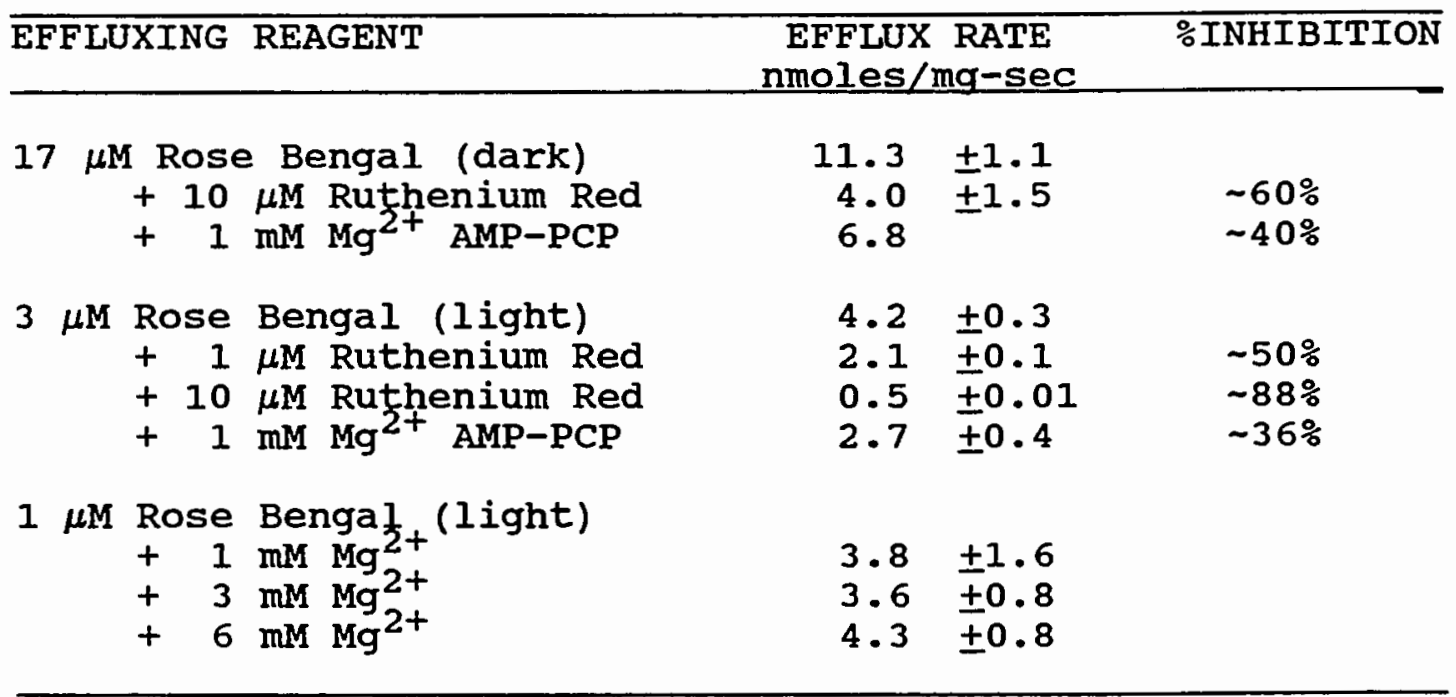

SR vesicles were actively loaded as described in Figure 9. After accumulation of the added calcium, the reagent to be tested was added, then efflux was initiated by the addition of rose bengal. Percent inhibition was calculated by comparing the $\mathrm{Ca}^{2+}$ efflux rate to the rate initiated by rose bengal alone The standard deviation shown is for $n>3$ data points. 
dye, has a $\lambda_{\max }=665 \mathrm{~nm}$. No shift of the $\lambda_{\max }$ or intensity of absorbance of methylene blue was observed in the presence of ruthenium red indicating that there was little, if any, dye-dye interaction or photon shielding (see Figure 11).

The photodynamic action observed in the efflux experiments probably proceeds via a singlet oxygen intermediate. To test whether ruthenium red inhibition of rose bengal-induced $\mathrm{Ca}^{2+}$ release was caused by inhibition of singlet oxygen production, the method described by Kraljic et al. (105) was used. In this method, the triplet state of the sensitizer transfers its energy to oxygen resulting in singlet oxygen formation. The singlet oxygen oxidizes imidazole to a transannular peroxide intermediate (see $r \times 2-5$ in chapter II) with the subsequent bleaching of p-nitrosodimethylaniline (RNO). Figure 12 shows the bleaching effect of rose bengal and methylene blue in the presence or absence of ruthenium red. Ruthenium red prevents the production of singlet oxygen by rose bengal but not methylene blue. Therefore, the inhibition of $\mathrm{Ca}^{2+}$ release induced by $3 \mu \mathrm{M}$ irradiated rose bengal may be due interference of ruthenium red with the singlet oxygen production. The complex formed when ruthenium red and rose bengal are added together seems to be photodynamically inactive. 

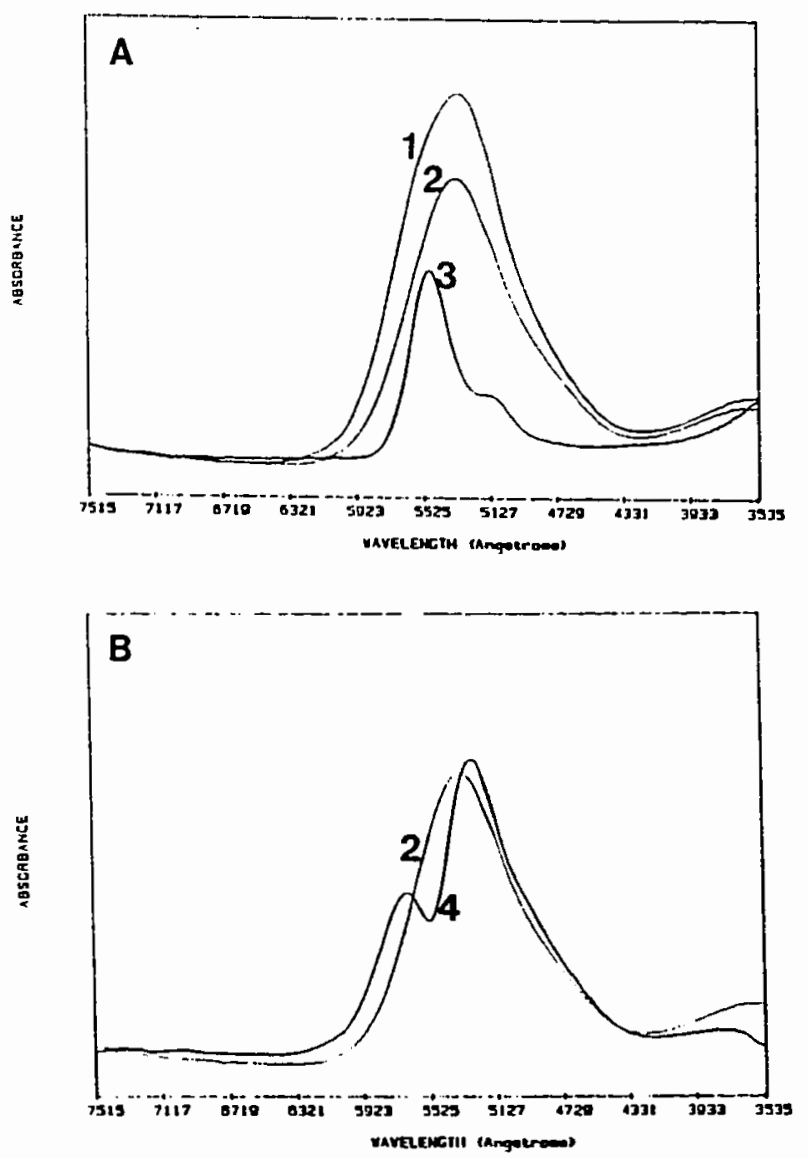

Figure 11. Spectra of rose bengal and methylene blue in the presence or absence of ruthenium red. The absorbance spectrum of $1 \mu \mathrm{M}$ rose bengal ( $\mathrm{A}$ : spectrum 3), $1 \mu \mathrm{M}$ ruthenium red (A: spectrum 2) or $1 \mu \mathrm{M}$ rose bengal $+1 \mu \mathrm{M}$ ruthenium red ( $\mathrm{A}$ : spectrum 1) was determined. In $B$ the difference between spectrum 1 and spectrum 3 (represented by \#4) is overlayed on spectrum 2. Since they do not match it indicates that a complex is being formed. 

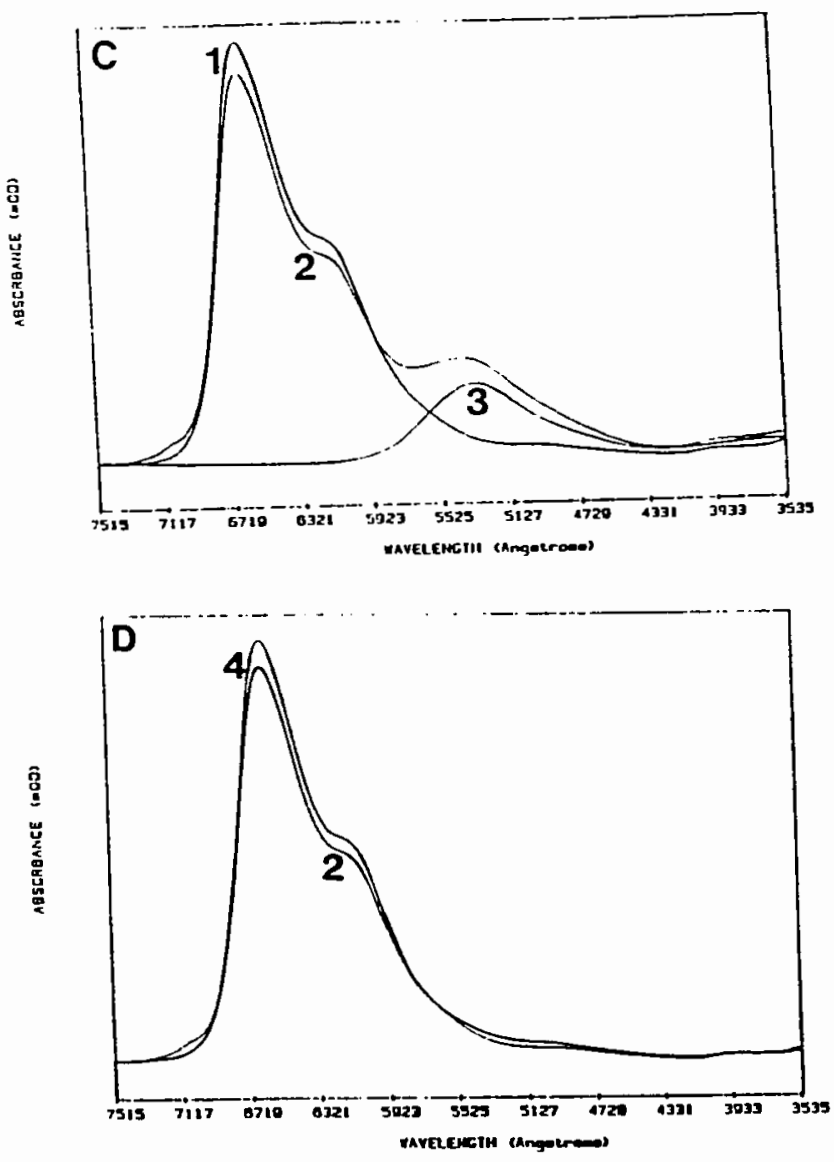

Figure 11b. Spectra of rose bengal and methylene blue in the presence or absence of ruthenium red. The absorbance spectrum of $1 \mu \mathrm{M}$ methylene blue (C: spectrum 2), $3 \mu \mathrm{M}$ ruthenium red (C: spectrum 3) or $1 \mu \mathrm{M}$ methylene blue $+3 \mu \mathrm{M}$ ruthenium red (C: spectrum 1) was determined. In $D$ the difference between spectrum 1 and spectrum 3 (represented by \#4) is overlayed on spectrum 2. The two curves match indicating that there is no dye-dye interaction. 

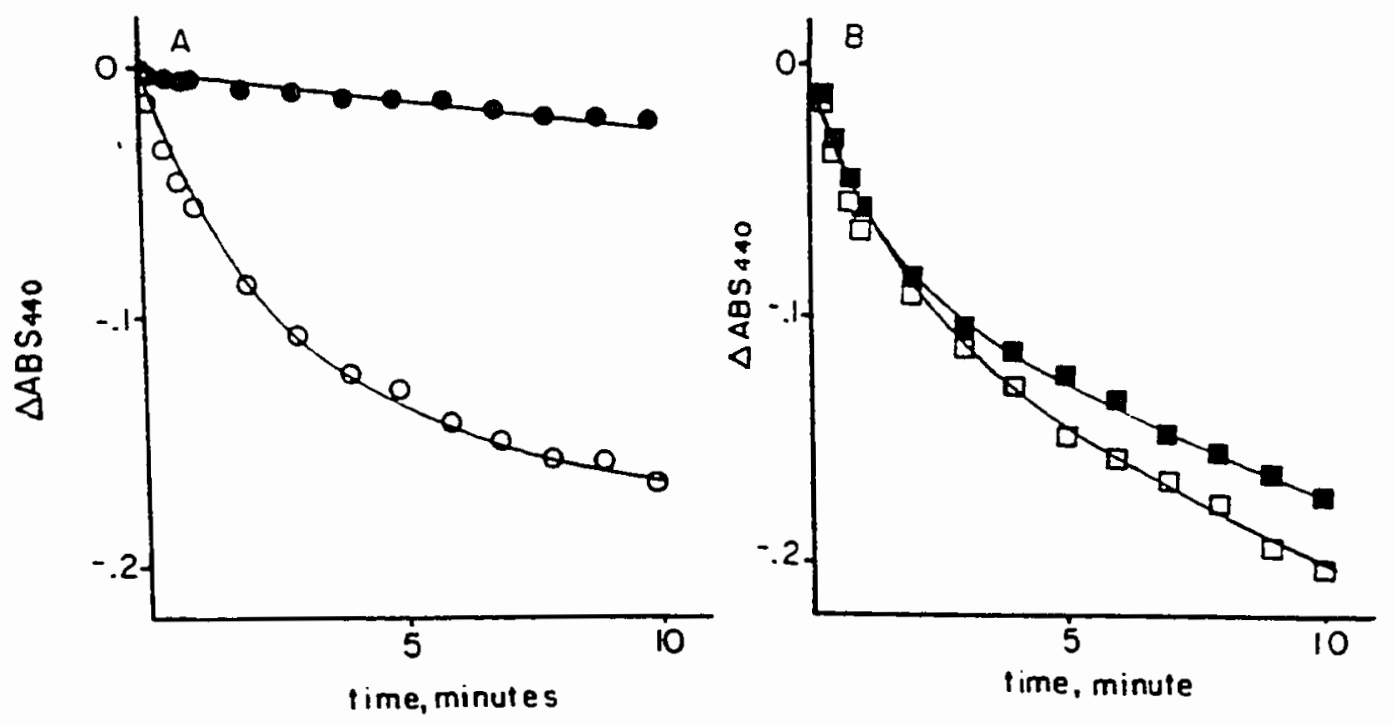

Figure 12. Detection of singlet oxygen production. The reaction solution contained 50 $\mu \mathrm{M}$ RNO, $8 \mathrm{mM}$ imidazole in $100 \mathrm{mM} \mathrm{KCl}, 50 \mathrm{mM}$ Hepes, $\mathrm{pH} 7.0$ buffer, $3 \mu \mathrm{M}$ rose bengal in presence ( $)$ ) or absence (O) of $10 \mu \mathrm{M}$ ruthenium red or $20 \mu \mathrm{M}$ methylene blue in the presence ( or absence ( $\square$ ) or ruthenium red. The solution was then illuminated with a 360-watt broad spectrum light source and the decrease in Abs 440 was followed as a function of time. 
Ruthenium red did not interfere with the photodynamic action of methylene blue. Therefore, the $\mathrm{Ca}^{2+}$ releasing action of methylene blue was examined in the presence and absence of ruthenium red. It can be seen in Figure 13 that ruthenium red does not protect the SR from the action of methylene blue at irradiation times between 1 minute and 10 minutes. The amount of $\mathrm{Ca}^{2+}$ effluxed is almost the same when actively loaded SR vesicles are treated with $10 \mu \mathrm{M}$ methylene blue in the presence or absence of $10 \mu \mathrm{M}$ ruthenium red. Therefore, the photooxidation target on the SR is not likely a ruthenium red sensitive component.

The rose bengal action at concentrations greater than $5 \mu \mathrm{M}$ is independent of photooxidation therefore photon shielding cannot explain the protective action of ruthenium red on the "dark" reaction. Rose bengal is known to bind to the SR $(90,116,120-121)$ and partition into lipid bilayers (116). The binding of the dye may interact with the membrane resulting in non-specific leakiness. The binding of ruthenium red to the membrane may prevent the binding of rose bengal to these sites. From spectral data, it has been shown that rose bengal and ruthenium red form some type of complex. Therefore, it is more likely that this complex either does not interact with the "Ca ${ }^{2+}$ release site", or does not incorporate into the bilayer even in the dark.

Table $V$ shows the effect of rose bengal on asolectin vesicles (ALV) loaded with $\mathrm{Ca}^{2+}$. Using the $\mathrm{Ca}^{2+}$-selective 


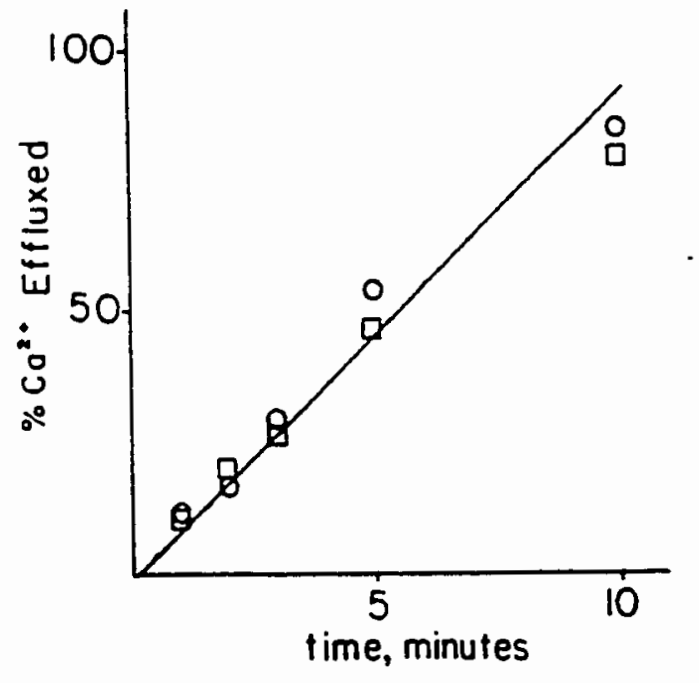

Figure 13. Methylene blue-induced $\mathrm{Ca}^{2+}$ release. $S R$ vesicles were actively loaded as described in Figure 9 using APIII. $10 \mu \mathrm{M}$ methylene blue, in the presence $(\square)$ or absence $(\square)$ of $10 \mu \mathrm{M}$ ruthenium red was added before uptake was started. After all the added $\mathrm{Ca}^{2+}$ had been accumulated, the sample was removed from the spectrophotometer. The sample then was irradiated for the specified time and returned to the spectrophotometer. The increase in the dye signal indicated was directly related to the amount of $\mathrm{Ca}^{2+}$ that had effluxed from the vesicles. To determine the amount of $\mathrm{Ca}^{2+}$ remaining in the vesicles, A23187 was added. The percentage $\mathrm{Ca}^{2+}$ effluxed was calculated by dividing the amount of $\mathrm{Ca}^{2+}$ effluxed by the total amount of $\mathrm{Ca}^{2+}$ in the vesicles before the addition of methylene blue. 
TABLE V

ROSE BENGAL-INDUCED CALCIUM RELEASE FROM ASOLECTIN VESICLES

EFFLUXING CONDITION

$0 \mu \mathrm{M}$ rose bengal

$3 \mu \mathrm{M}$ rose bengal +1 minute light

+2 minute light

$10 \mu \mathrm{M}$ rose bengal (dark)

+4 minutes

+8 minutes

$\mathrm{Ca}^{2+}$ IN $\mathrm{ALV}$

$5.7 \mu \mathrm{M}$

$5.7 \mu \mathrm{M}$

$5.4 \mu \mathrm{M}$

$5.5 \mu \mathrm{M}$

$5.2 \mu \mathrm{M}$
\% EFFLUXED

0

0

$\sim 4 \frac{9}{8}$

$-3 \%$

$\sim 9 \%$

Asolectin vesicles, prepared as described in chapter II, were diluted $75 \mathrm{x}$ into $100 \mathrm{mM} \mathrm{KCl}, 50 \mathrm{mM}$ Hepes, $\mathrm{pH} 7.0$, $1 \mathrm{mM} \mathrm{Mg}^{2+}$. Rpse bengal was added and the light source turned on. $\mathrm{Ca}^{2+}$ efflux was followed using $100 \mu \mathrm{M}$ of the $\mathrm{Ca}^{2+}$-sensitive dye APIII. 
dye, antipyrylazo III, the $\mathrm{Ca}^{2+}$ remaining in the vesicles after treatment was measured. As can be seen, $10 \mu \mathrm{M}$ rose bengal did not significantly increase the permeability of the ALV to $\mathrm{Ca}^{2+}$. The incubation of the ALV with $3 \mu \mathrm{M}$ rose bengal and irradiated for 1 or 2 minutes also resulted in no increase in the $\mathrm{Ca}^{2+}$ permeability of the ALV. These results indicate that the action of the rose bengal is not likely to be caused by oxidation of the lipid component of the $S R$ vesicles.

The physiological $\mathrm{Ca}^{2+}$ release pathway from $\mathrm{SR}$ is believed to be localized in the junctional region adjacent to the transverse tubule. $\mathrm{Ca}^{2+}$-induced (10) and -SH oxidation-induced (22) $\mathrm{Ca}^{2+}$ release have been shown to be specific for $S R$ vesicles derived from the terminal cisternae region (HSR). As shown in Figure 14, $\mathrm{Ca}^{2+}$ efflux induced by rose bengal is $40 \%$ more effective in HSR than in $S R$ derived from the longitudinal region of the SR (LSR). The LSR is essentially devoid of $\mathrm{Ca}^{2+}$ release channel, therefore the increased $\mathrm{Ca}^{2+}$ permeability of LSR in the presence of rose bengal is likely to be due to modification of some component other than the $\mathrm{Ca}^{2+}$ release channel.

As shown in Chapter III of this thesis, the presence of adenine nucleotides stimulates oxidation-induced $\mathrm{Ca}^{2+}$ release (-SH oxidation) (81, 83, 124). Adenine nucleotides are also known to stimulate $\mathrm{Ca}^{2+}$-induced $\mathrm{Ca}^{2+}$ release (57, $63,68,70,123)$. In an attempt to determine if the 


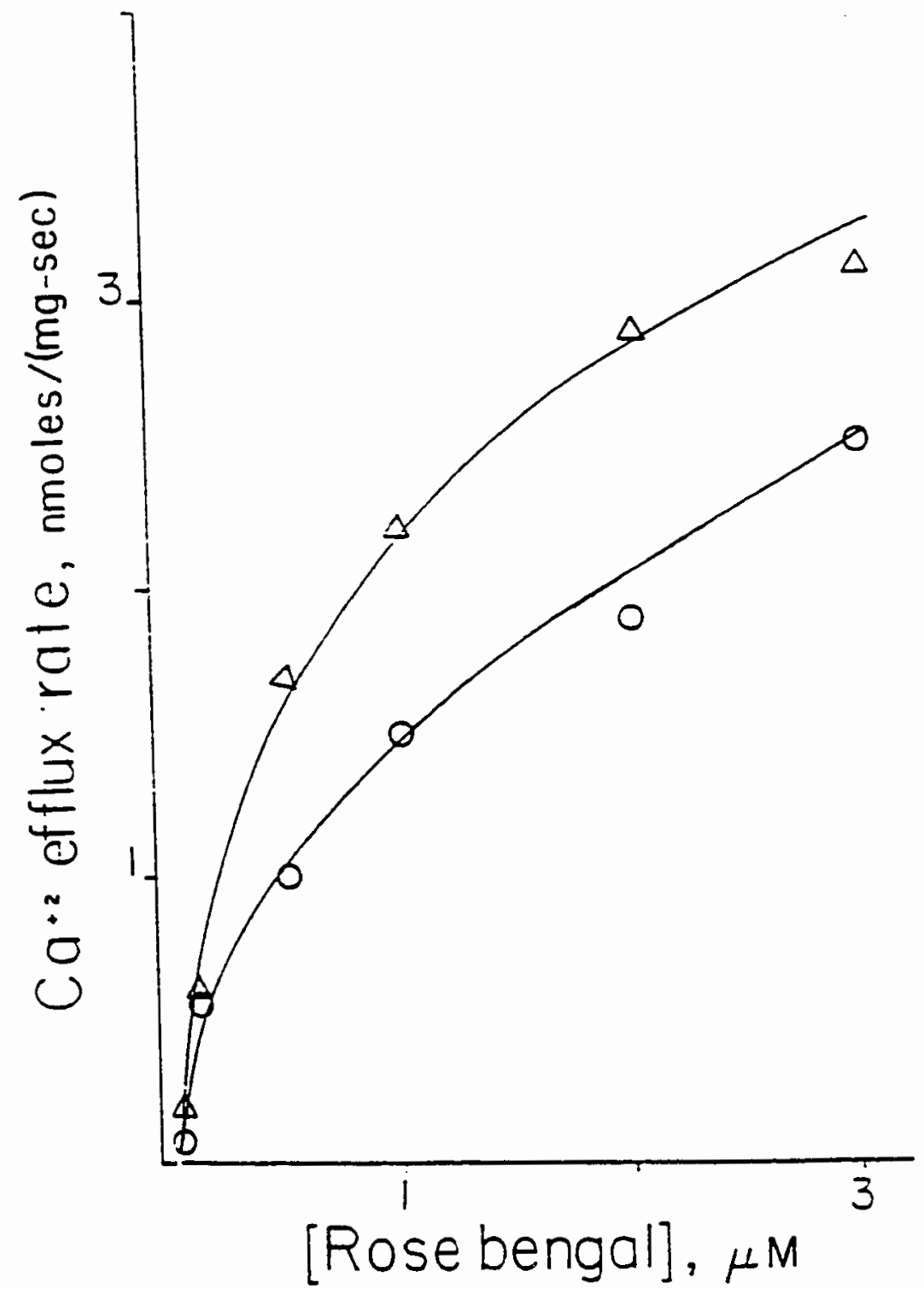

Figure 14. Comparison of rose bengal-induced $\mathrm{Ca}^{2+}$ release from $\mathrm{HSR}$ and LSR. HSR ( $\triangle$ ) or LSR (O) vesicles were actively loaded as described in Figure 9. After accumulation of $\mathrm{Ca}^{2+}$, efflux was initiated by the addition of various concentrations of rose bengal plus illumination. 
adenine nucleotide binding site might be the photodynamic target, the interaction between rose bengal-induced $\mathrm{Ca}^{2+}$ efflux and adenine nucleotide stimulation of $\mathrm{Ca}^{2+}$ release was monitored. As seen in Table IV, efflux rates induced by rose bengal in the presence of $1.0 \mathrm{mM} \mathrm{Mg}^{2+}-\mathrm{AMP}-\mathrm{PCP}$ are inhibited $-40 \%$. The presence of AMP-PCP appears to protect the photooxidation target.

Unlike oxidation-induced $\mathrm{Ca}^{2+}$ efflux which is inhibited by increasing concentrations of $\mathrm{Mg}^{2+}(22,8283$, 124-125), the rose bengal-induced $\mathrm{Ca}^{2+}$ efflux rate is not affected by the external $\mathrm{Mg}^{2+}$ concentration. Table IV shows that at $\mathrm{Mg}^{2+}$ concentrations as high as $6 \mathrm{mM}$ the rose bengal-induced $\mathrm{Ca}^{2+}$ efflux rates remaining unaltered. Figure 15 shows that rose bengal-induced $\mathrm{Ca}^{2+}$ efflux rates are only slightly affected by the external $\mathrm{Ca}^{2+}$ concentration. The $\mathrm{Ca}^{2+}$ efflux rate decreases slightly with increasing external $\mathrm{Ca}^{2+}$ concentration. This suggests that high $(100 \mu \mathrm{M})$ concentrations of $\mathrm{Ca}^{2+}$ may slightly protect the photooxidation site. The $\mathrm{Ca}^{2+}$ dependent profile of rose bengal-induced $\mathrm{Ca}^{2+}$ release is considerably different than the $\mathrm{Ca}^{2+}$ dependence of $\mathrm{Ca}^{2+}$-induced $\mathrm{Ca}^{2+}$ release $(49,57-58)$, or oxidation induced release (83).

In addition to triggering rapid $\mathrm{Ca}^{2+}$ release from actively loaded SR vesicles, rose bengal is shown to trigger $\mathrm{Ca}^{2+}$ release from passively loaded vesicles. Figure $16 \mathrm{a}$ shows that the amount of $\mathrm{Ca}^{2+}$ remaining in the 


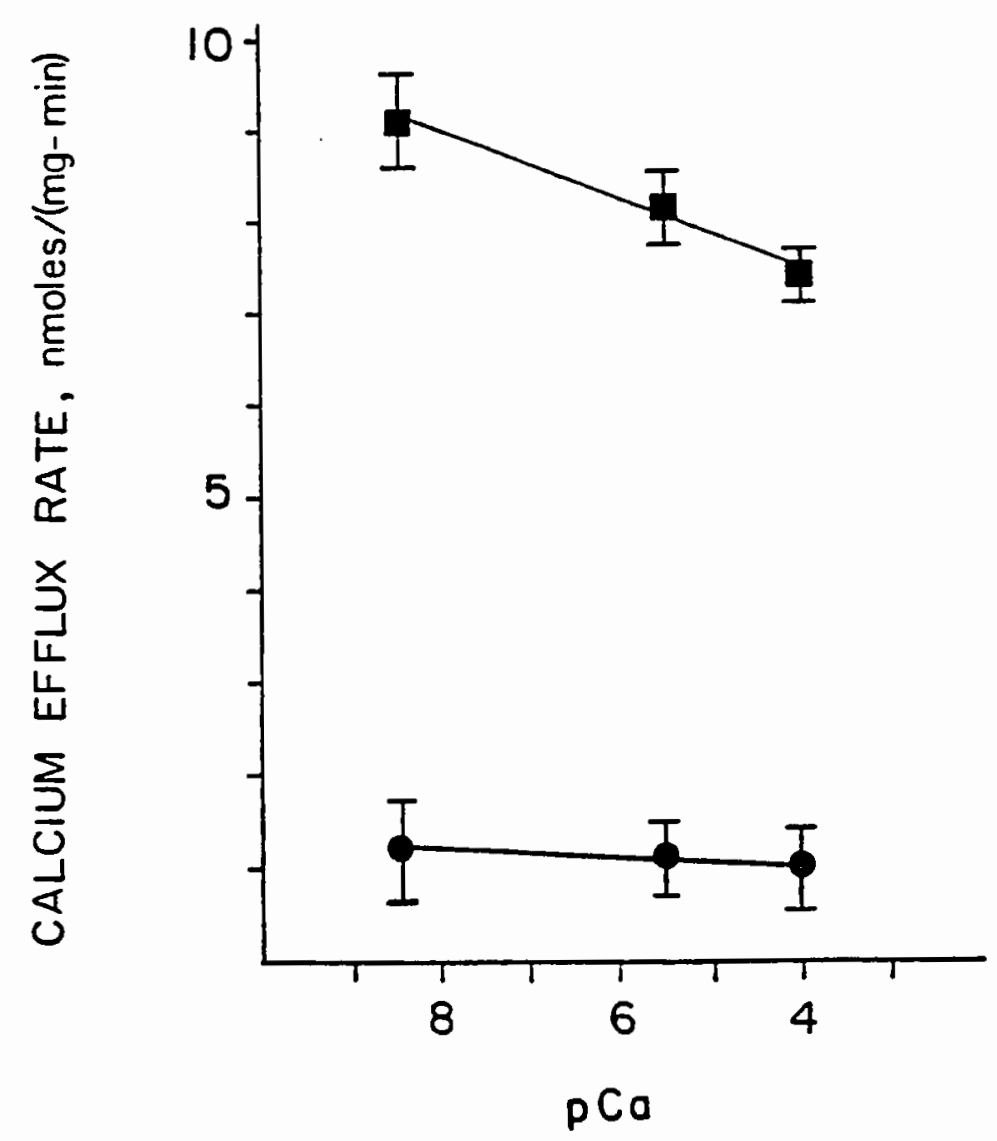

Fiqure 15 . $\mathrm{Ca}^{2+}$ dependence of rose bengalinduced $\mathrm{Ca}^{2+}$ efflux. SR vesicles were incubated overnight at $0^{\circ} \mathrm{C}$ in a medjum containing $100 \mathrm{mM}$ $\mathrm{KCl}, 5 \mathrm{mM} \mathrm{MgCl}_{2}$, and $1 \mathrm{mM}{ }^{4} \mathrm{CaCl}_{2}$, $50 \mathrm{mM}$ Hepes, $\mathrm{pH} 7.0$ at a protein concentration of $10 \mathrm{mg} / \mathrm{mL}$. Vesicles were diluted 50x into effluxing buffer containing $100 \mathrm{mM} \mathrm{KCl}, 5 \mathrm{mM} \mathrm{\textrm {MCl } _ { 2 }}$, $50 \mathrm{mM}$ Hepes, $\mathrm{pH} 7.0$, with various concentrations of $\mathrm{Ca}^{2}$ buffered to the desired concentration with EGTA. The final $\mathrm{Ca}^{2+}$ concentration was calculated using the stability constants reported by Fabiato (148). The samples were irradiated with a 360watt light source in the presence ( $\square$ ) or absence ( ) of $200 \mathrm{nM}$ rose bengal. After a specified time, aliquots (containing $0.04 \mathrm{mg}$ of SR protein) were filtered through a millipore filter (.45 micron) and washed with $1 \mathrm{~mL}$ of buffer containing high concentrations of unlabeled $\mathrm{Ca}^{2+}$ and $\mathrm{Mg}^{2+}(5 \mathrm{mM}$ each). The filter was suspended in scintillation fluid and counted. Efflux rates were determined by calculating the absolute value of the slope of a plot of ${ }^{45} \mathrm{Ca}^{2+}$ remaining in the vesicles (nmoles/mg) versus time (minute). 
vesicles decreases with the increasing time of exposure to rose bengal. In Figure 16b, SR vesicles were incubated with various concentrations of rose bengal for 5 minutes, and the amount of $\mathrm{Ca}^{2+}$ remaining in the vesicles was measured. The amount of $\mathrm{Ca}^{2+}$ remaining in the vesicles decreases with increasing concentration of rose bengal until $50 \mathrm{nM}$ rose bengal. Between $50 \mathrm{nM}$ and $100 \mathrm{nM}$ rose bengal there is no difference in the amount of $\mathrm{Ca}^{2+}$ release after 5 minutes $(\sim 70 \%)$; however, at $1 \mu \mathrm{M}$ rose bengal essentially all of the $\mathrm{Ca}^{2+}$ has been released within 5 minutes. This biphasic behavior may be due to an interaction with two types of sites. Modification of a highly reactive site causes release of $70 \%$ of the $\mathrm{Ca}^{2+}$ while the remaining $30 \%$ is released at slightly higher concentrations of rose bengal. Unlike the earlier figures (Figures 8-10) in which $\mathrm{Ca}^{2+}$ had been actively accumulated and $\mathrm{Ca}^{2+}$ release was triggered by the addition of rose bengal, these experiments, using passively loaded vesicles, were carried out at significantly lower rose bengal concentrations, while the vesicles were incubated with rose bengal for significantly longer periods of time.

\section{DISCUSSION}

It has been previously shown that oxidation of sulfhydryl groups on the $S R$ results in rapid release of internal $\mathrm{Ca}^{2+}(22,82,83,124-125)$. This effect is 

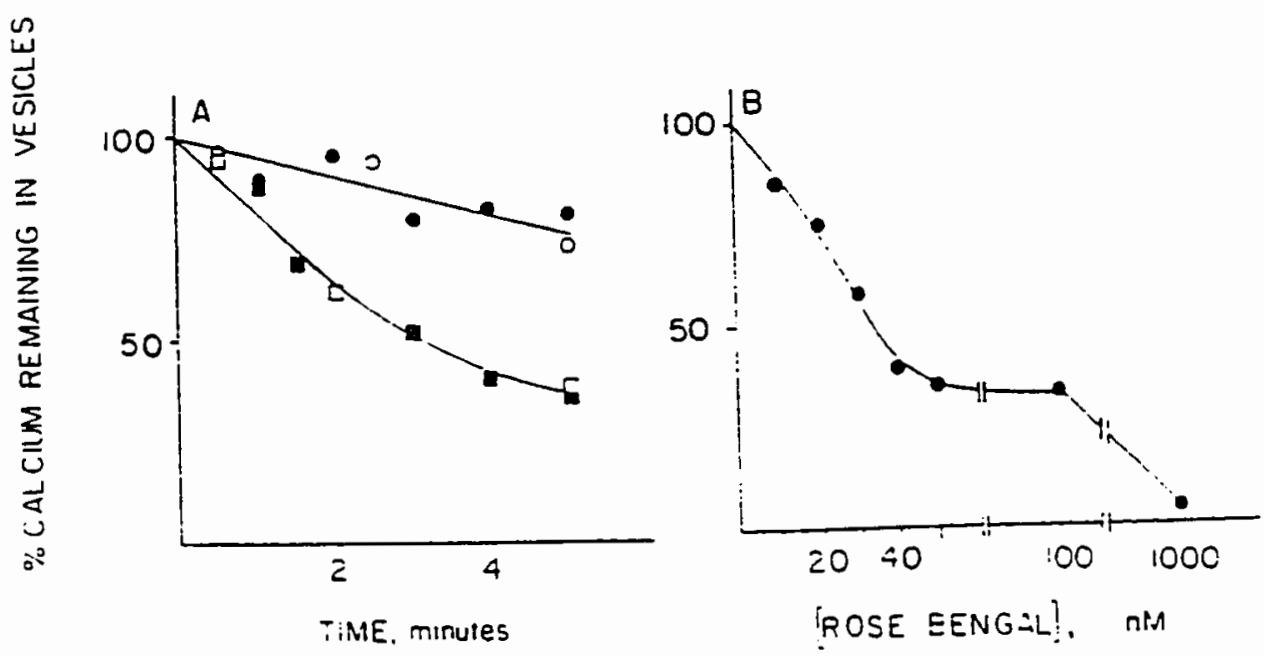

Fiqure 16. Rose bengal-induced $\mathrm{Ca}^{2+}$ efflux from passively loaded vesicles. SR vesicles were incubated overnight as described in Figure 4. SR vesicles were diluted into a buffer containing $100 \mathrm{mM} \mathrm{KCl}, 5 \mathrm{mM} \mathrm{MgCl}_{2}, 50 \mathrm{mM}$ Hepes, $\mathrm{pH} 7.0$ and various concentrations of rose bengal. The samples were irradiated with a 360-watt light source at $30 \mathrm{~cm}$ for the designated time. $100 \mu \mathrm{M}$ AsIII was then added, an absorbance baseline established, and $-1.0 \mu M, A 23187$ added to determine the amount of $\mathrm{Ca}^{2+}$ remaining in the vesicles. One aliquot of $4-8 \mu \mathrm{M} \mathrm{Ca}{ }^{2+}$ was added to calibrate the AsIII-Ca ${ }^{2+}$ signal. The percentage remaining in the vesicles was calculated by using the amount of A23187 releasable $\mathrm{Ca}^{2+}$ from untreated $S R$ vesicles a 100\%. Figure 16a shows the amount of $\mathrm{Ca}^{2+}$ release as a function of time at a rose bengal concentration of $(O) 10 \mathrm{nM},(O) 20$ $\mathrm{nM},(\square) 50 \mathrm{nM}$ and $(\square) 100 \mathrm{nM}$. Figure 16b shows the dependence on rose bengal concentration after incubation for 5 minutes. 
stimulated by adenine nucleotides $(22,82,83,124-125)$ and inhibited by $\mathrm{Mg}^{2+}(22,82,83,124-125)$ and ruthenium red $(22,82,83,124-125)$. In this chapter, it is shown that photooxidation of the $S R$ by rose bengal induces rapid release of the internal $\mathrm{Ca}^{2+}$. Unlike -sH oxidation, photooxidation is not $\mathrm{Mg}^{2+}$ dependent, and $\mathrm{Ca}^{2+}$ release is only partially inhibited by ruthenium red. The addition of ruthenium red $(10 \mu \mathrm{M})$ prior to the addition of rose bengal (17 $\mu \mathrm{M}$ in the dark) leads to a $-60 \%$ inhibition of the $\mathrm{Ca}^{2+}$ release rate. The inhibition of the photooxidation action of $3 \mu \mathrm{M}$ rose bengal by ruthenium red is most likely due to formation of an photo inactive complex between rose bengal and ruthenium red. The presence of ruthenium red totally inhibits the production of singlet oxygen by rose bengal. It has been shown that methylene blue is an effective singlet oxygen producer even in the presence of ruthenium red. Methylene blue-induced $\mathrm{Ca}^{2+}$ release is not inhibited by ruthenium red, suggesting that $\mathrm{Ca}^{2+}$ release induced by methylene blue in the presence of light is not caused by an interaction with the ruthenium red sensitive $\mathrm{Ca}^{2+}$ release channel. It is also possible that the $\mathrm{Ca}^{2+}$ release channel is altered by photooxidation in such a way that it is no longer sensitive to ruthenium red.

$\mathrm{Mg}^{2+}$ may alter efflux rates by binding to the $\mathrm{Ca}^{2+}$ activator site. Increasing $\mathrm{Mg}^{2+}$ inhibits $\mathrm{Ca}^{2+}$ efflux rates stimulated by $-\mathrm{SH}$ oxidation (22) and $\mathrm{Ca}^{2+}(41,57,62)$. 
Photooxidation of the SR removes the $\mathrm{Mg}^{2+}$ dependence of the $\mathrm{Ca}^{2+}$ efflux rate. Similarly, the $\mathrm{Ca}^{2+}$ dependence of the $\mathrm{Ca}^{2+}$ release rate triggered by rose bengal is considerably different than release triggered by adenine nucleotides $(68,70)$, or via sulfhydryl oxidation (83). This implies that either 1) $\mathrm{Ca}^{2+} / \mathrm{Mg}^{2+}$ binding site(s) is (are) susceptible to photooxidation or 2) photomodification may alter the normal gating mechanism of the $\mathrm{Ca}^{2+}$ release protein so dramatically that many of the normal modulators of $\mathrm{Ca}^{2+}$ transport no longer effectively interact or 3) photooxidation-induced $\mathrm{Ca}^{2+}$ release is through an SR protein component different from the $\mathrm{Ca}^{2+}$ release protein. AMP-PCP protection of the SR from photooxidation with rose bengal suggests that the photomodification site is part of or close to an adenine nucleotide binding site. All the known modulators of $\mathrm{Ca}^{2+}$ release $(10,57,68,123)$ affect rose bengal-stimulated $\mathrm{Ca}^{2+}$ release differently than previously observed for $\mathrm{Ca}^{2+}$-induced or oxidation-induced $\mathrm{Ca}^{2+}$ release. This different response could be due to a disruption of communication between the gating mechanism and the modulatory site. Alternatively, $\mathrm{Ca}^{2+}$ release induced by rose bengal may involve a totally different molecular interaction with the $\mathrm{Ca}^{2+}$. transport system of the SR. It is also possible that the $\mathrm{Ca}^{2+}$ release observed here is through a pathway completely different and distinct from the $\mathrm{Ca}^{2+}$ release channel. 
The ISR is susceptible to the action of rose bengal even though LSR is essentially devoid of $\mathrm{Ca}^{2+}$ release channels. Moreover, rose bengal-induced $\mathrm{Ca}^{2+}$ release is $\approx 40 \%$ more effective in HSR than in LSR. This suggests that there is a photo-reactive component in HSR that is found at a higher density in the terminal cisternae region of the SR than in the longitudinal SR. The possibility that the rose bengal might be affecting the integrity of the membrane by oxidizing the phospholipids was examined. It was shown that the action of rose bengal did not significantly increase $\mathrm{Ca}^{2+}$ permeability of $\mathrm{ALV}$ loaded with $\mathrm{Ca}^{2+}$ suggesting that rose bengal-induced $\mathrm{Ca}^{2+}$ release is probably not due to the oxidation of membrane lipids. Rose bengal is a binding dye which can partition into the lipids $(90,116)$ and possibly disrupt protein/1ipid interactions. There are also other cation/anionic channels present throughout the entire SR membrane system (57, 130). Photomodification may affect any or all of these channels, and disrupt their specificity. As a result of this, $\mathrm{Ca}^{2+}$ may now be transported through a system which normally transports monovalent cations or anions. The possibility that photooxidizable targets are reactive sites on ionic channels other than the $\mathrm{Ca}^{2+}$ release channel found in the terminal cisternae has been examined, however no conclusive evidence has been found (see Chapter 6). 
Preliminary data indicate that the photo-reactive site may be a histidyl residue. Histidyl residues have previously been reported as photooxidation targets on SR vesicles (87-90). Kondo and Kasai (90) reported the possibility of tryptophan modification by the photodynamic action of xanthene dyes. Watson and Haynes (121) reported that photomodification of SR vesicles resulted in crosslinking of some of the SR proteins. There is some crosslinking of $S R$ proteins when $S R$ vesicles are irradiated in the presence of $3 \mu \mathrm{M}$ rose bengal for 30 seconds or longer (see Chapter 6). At 30 seconds there is a loss of two minor protein components, -61 and $-135 \mathrm{~K}$ daltons, observed on SDS-PAGE. At $3 \mu \mathrm{M}$ rose bengal (plus irradiation) all the $\mathrm{Ca}^{2+}$ is effluxed within 30 seconds. Further work needs to be done before definite conclusions can be made regarding the importance of this photo-induced crosslinking.

In summary, very low concentrations of rose bengal induce rapid $\mathrm{Ca}^{2+}$ efflux from $\mathrm{SR}$ vesicles. This effect is partially inhibited by ruthenium red and AMP-PCP but is unaffected by $\mathrm{Mg}^{2+}$. The membrane lipids are unaffected by rose bengal in the presence or absence of light. HSR is $\sim 40 \%$ more sensitive to photooxidation than LSR. There is a photo-reactive target which is found at a higher density in vesicles derived from the terminal cisternae than from 
those derived from the longitudinal $S R$. This reactive component may be the $\mathrm{Ca}^{2+}$ release channel. 
CHAPTER V

THE ROLE OF HISTIDYL RESIDUES IN CALCIUM EFFLUX FROM SARCOPLASMIC RETICULUM VESICLES

\section{SUMMARY}

Photooxidation of $S R$ vesicles results in the appearance of an absorbance band at $250 \mathrm{~nm}$ after 30 seconds of illumination. After 10 minutes of illumination a second absorbance band appears at $-306 \mathrm{~nm}$. These bands appear to result from oxidation of histidyl and tryptophanyl residues, respectively. The presence of $40 \mathrm{mM}$ histidine in the effluxing buffer inhibits $\mathrm{Ca}^{2+}$ efflux rates $\sim 40 \%$. The presence of $40 \mathrm{mM}$ cysteine or lysine did not affect the efflux rates. Ethoxyformic anhydride (EFA), a histidine modifying reagent, induces $\mathrm{Ca}^{2+}$ efflux from SR vesicles. similar to rose bengal-induced $\mathrm{Ca}^{2+}$ efflux, EFA-induced $\mathrm{Ca}^{2+}$ efflux is $\mathrm{Mg}^{2+}$ independent and is inhibited by ATP. High $\mathrm{Mg}^{2+}$ concentrations increase the time between the addition of EFA and the initiation of $\mathrm{Ca}^{2+}$ release indicating there is some protection of the reaction site by the presence of $\mathrm{Mg}^{2+}$ even though the maximal efflux rates are $\mathrm{Mg}^{2+}$ independent. The AMP-PCP protection of SR proteins from modification with EFA is similar to noncompetitive inhibition observed in some enzyme systems. 
INTRODUCTION

Elucidating the functional role of a particular amino acid in a transport protein is an important task in describing the molecular basis for transport. one way to determine the role of amino acids is through chemical modification. Sulfhydryl oxidation (22) and lysine modification $(86,126)$ have been shown to enhance $\mathrm{Ca}^{2+}$ efflux in the SR. The modification of free carboxylic groups results in the decrease of $\mathrm{Ca}^{2+}$ fluxes in $\mathrm{SR}$ vesicles (129-131).

Tenu et al. (87) report that treatment of the SR with EFA results in the modification of 1 mole lysine and 1-2 mole histidine per mole of ATPase. This decreases $\mathrm{Ca}^{2+}$, $\mathrm{Mg}^{2+}$-ATPase activity and uncouples active $\mathrm{Ca}^{2+}$ transport from ATPase activity. Coffey et al. (132) reported that the modification of histidyl residues was not important in ATPase activity or $\mathrm{Ca}^{2+}$ uptake. However, photooxidation experiments suggest that histidyl residues (88-90) or possibly tryptophanyl residues (90) are involved in active $\mathrm{Ca}^{2+}$ transport.

\section{RESULTS}

In Chapter IV, it has been shown that photooxidation of $S R$ vesicles results in rapid release of the internal $\mathrm{Ca}^{2+}$. It is of interest to determine the target for this photooxidation reaction since several amino acids are 
susceptible to oxidation, including cysteine, histidine, tryptophan and tyrosine. It has previously been reported that histidine oxidation, via a singlet oxygen mechanism, proceeds more quickly than the photooxidation of other amino acids (101).

Table VI shows that rose bengal-induced $\mathrm{Ca}^{2+}$ efflux rates, both in the dark and light, are inhibited by a large excess of histidine. However, a large excess of cysteine does not inhibit $\mathrm{Ca}^{2+}$ efflux induced by rose bengal. These data are consistent with, but not conclusive for, the involvement of histidyl residues in the photooxidation process.

Photooxidation of proteins has been reported to induce crosslinking of the $\mathrm{Ca}^{2+}, \mathrm{Mg}^{2+}$-ATPase (121). Among the possible intermediate products of histidine photooxidation are aldehydes which can subsequently condense with an amino group resulting in the crosslinking of proteins. This crosslinking can be prevented by either succinylation of free amino groups or the addition of excess free amino groups (101). Although this secondary reaction (aldehyde condensation) is relatively slow, crosslinking of SR proteins may result, producing a non-specific leakiness of the vesicles. To test if crosslinking was responsible for the $\mathrm{Ca}^{2+}$ efflux observed upon the addition of rose bengal, 
TABLE VI

COMPARISON OF THE EFFECT OF VARIOUS REAGENTS ON CALCIUM EFFLUX RATES FROM ROSE BENGAL TREATED VESICLES

\begin{tabular}{|c|c|c|c|c|}
\hline \multicolumn{2}{|c|}{ EFFLUXING REAGENT } & \multicolumn{2}{|c|}{$\begin{array}{c}\text { EFFLUX RATE } \\
\text { nmoles/mg-sec }\end{array}$} & $\%$ INHIBITION \\
\hline $\begin{array}{r}17 \mu \mathrm{M} \\
3 \mu \mathrm{M}\end{array}$ & $\begin{array}{l}\text { rose bengal (dark) } \\
+40 \mathrm{mM} \text { Histidine } \\
+40 \mathrm{mM} \text { Cysteine } \\
\text { rose bengal (light) } \\
+40 \mathrm{mM} \text { Histidine } \\
+40 \mathrm{mM} \text { Cysteine } \\
+40 \mathrm{mM} \text { Lysine }\end{array}$ & $\begin{array}{r}11.3 \\
8.0 \\
13.1 \\
4.2 \\
2.1 \\
4.6 \\
4.1\end{array}$ & $\begin{array}{l} \pm 1.1 \\
\pm 0.4 \\
\pm 3.0 \\
\pm 0.3 \\
\pm 0.6 \\
\pm 0.2 \\
\pm 0.01\end{array}$ & $\begin{array}{c}-30 \% \\
0 \\
-50 \% \\
0 \\
0\end{array}$ \\
\hline
\end{tabular}

SR vesicles were actively loaded as described in Figure 9. After accumulation of the added calcium, the reagent to be tested was added, then efflux was initiated by the addition of rose bengal. Percentage inhibition was calculated by comparing the $\mathrm{Ca}^{2+}$ efflux rate to the rate initiated by rose bengal alone. The standard deviation shown is for $n \geq 3$ data points. 
a large excess of lysine was added to the reaction buffer. The presence of the lysine should prevent protein crosslinking due to a condensation reaction between aldehydes formed and free amino groups on the proteins. In Table VI, it can be seen that the presence of the lysine did not alter the rose bengal-induced $\mathrm{Ca}^{2+}$ efflux rate.

Figure 17 shows the absorption spectrum resulting from photooxidation of histidine and tryptophan. As can be seen, the photooxidation of histidine (Figure 17a) is evidenced by the appearance of an absorbance peak at 233 $\mathrm{nm}$, while tryptophan photooxidation (Figure 17b) shows an increased absorbance at $\approx 301 \mathrm{~nm}$. Photooxidation of the SR results in an increase in the absorbance at $-250 \mathrm{~nm}$, a valley at $290 \mathrm{~nm}$, and after 10 minutes of illumination a second absorbance peak appears at $306 \mathrm{~nm}$. The peak at 250 $\mathrm{nm}$ probably corresponds to the $233 \mathrm{~nm}$ histidine peak. The red shift of the $\lambda_{\max }$ may be due to the environment in which the affected residue resides. The first photooxidation target on the $S R$ may be a histidyl residue followed at later times by the photooxidation of tryptophanyl residues.

Photooxidation of histidyl resides proceeds rapidly at $\mathrm{pH} 7.0$ and often shows a $\mathrm{pH}$ dependence similar to a titration curve of a monoprotic acid with a $\mathrm{pk}_{\mathrm{a}} \sim 7.0$. Tryptophan is more sensitive to photooxidation at $\mathrm{pH} 4.0$ than is histidine (101). The $\mathrm{pH}$ dependence of rose bengal- 

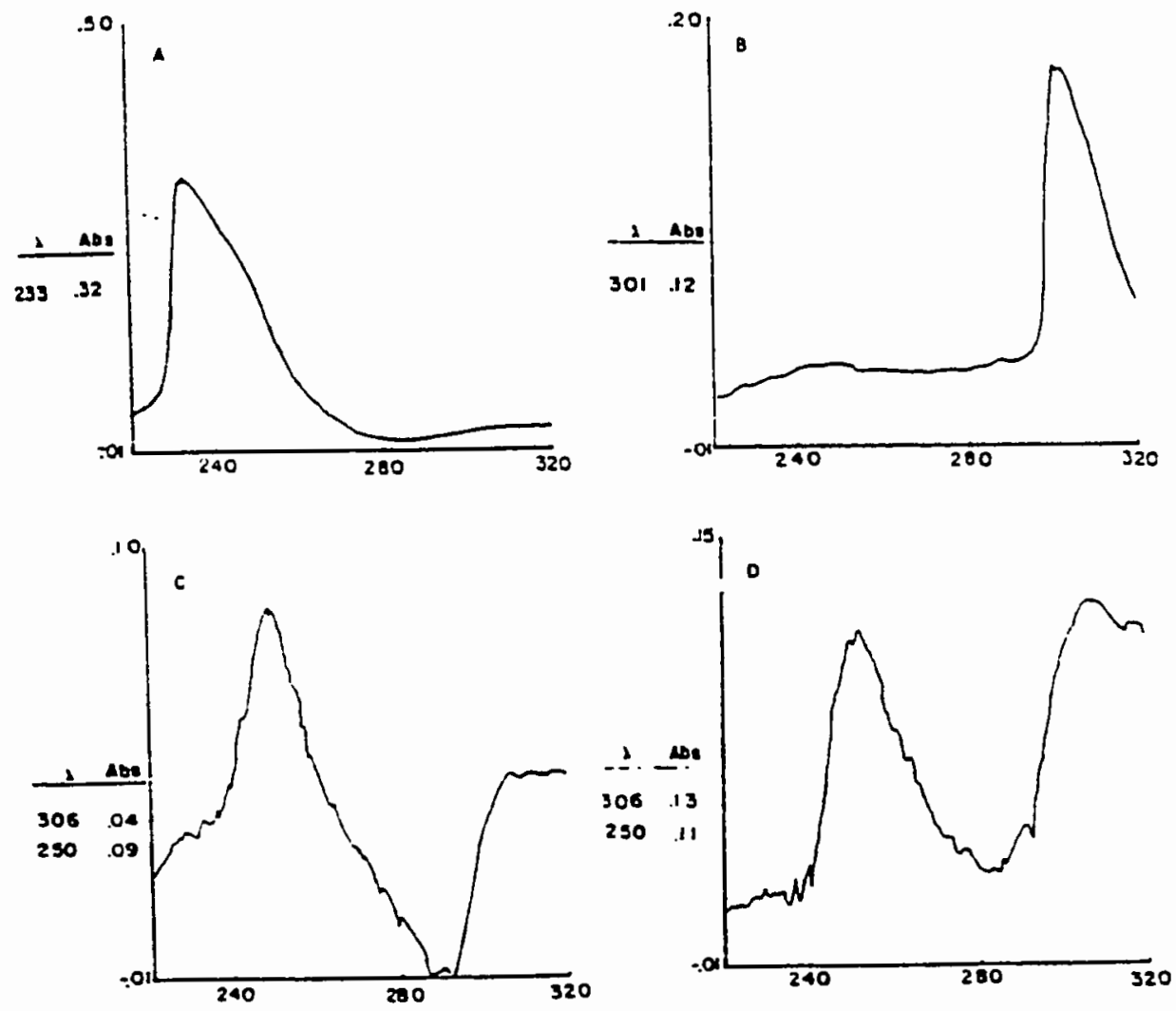

Figure 17. Difference absorbance spectra of histidine, tryptophan and SR vesicles after photooxidation. A buffer containing $100 \mathrm{mM} \mathrm{KCl}$, $50 \mathrm{mM}$ Hepes, $\mathrm{pH} 7.0,1 \mu \mathrm{M}$ rose bengal with (A) 5 $\mathrm{mM}$ histidine or (B) $5 \mathrm{mM}$ tryptophan was irradiated for 1 minute and the absorbance spectrum was measured. SR vesicles were diluted to a protein concentration of $0.2 \mathrm{mg} / \mathrm{mL}$ in the same buffer. 1 MM rose bengal was added and a sample baseline established. The sample was then irradiated for 1 minute (C) or 10 minutes (D) using a 360-watt broad spectrum light source at a distance of $-30 \mathrm{~cm}$. After irradiation, a spectrum of the sample was run. 
induced $\mathrm{Ca}^{2+}$ release is unusual because the $\mathrm{SR}$ is more sensitive to photooxidation at $\mathrm{pH} 6.0$ than at $\mathrm{pH} 8.0$ (Figure 18). It should be noted that the calculated rate constant (initial rate/amount of $\mathrm{Ca}^{2+}$ released) is less dramatically affected by $\mathrm{pH}$ than the measured $\mathrm{Ca}^{2+}$ efflux rate. The amount of $\mathrm{Ca}^{2+}$ released by rose bengal at $\mathrm{pH} 8.0$ is less than at $\mathrm{pH}$ 6.0. At high $\mathrm{pH}$ there appears to be fewer sites that can be oxidized by rose bengal. This unusual $\mathrm{pH}$ dependence suggests that the reactive histidine is influenced by the microenvironment in which it resides. The histidyl residue may form an ion pair with another amino acid thereby altering its reactivity (133-135). Another possibility, which is less likely, is that the photooxidation target is a tryptophanyl residue instead of a histidyl residue.

Figure 19 shows that after accumulation of added $\mathrm{Ca}^{2+}$ into the $S R$ vesicles the addition of millimolar concentrations of EFA, a histidine modifying reagent, results in the efflux of most of the accumulated $\mathrm{Ca}^{2+}$. There is a lag phase which decreases as the EFA concentration increases. The EFA-induced maximal $\mathrm{Ca}^{2+}$ efflux rate is $\mathrm{Mg}^{2+}$ independent; however, the lag phase increases with increasing $\mathrm{Mg}^{2+}$ concentration. This is similar to the results seen with rose bengal-induced $\mathrm{Ca}^{2+}$ release (see Chapter IV). Figure 20 shows that the $\mathrm{SR}$ is protected from EFA modification by the presence of $\mathrm{Mg}^{2+}$ as 


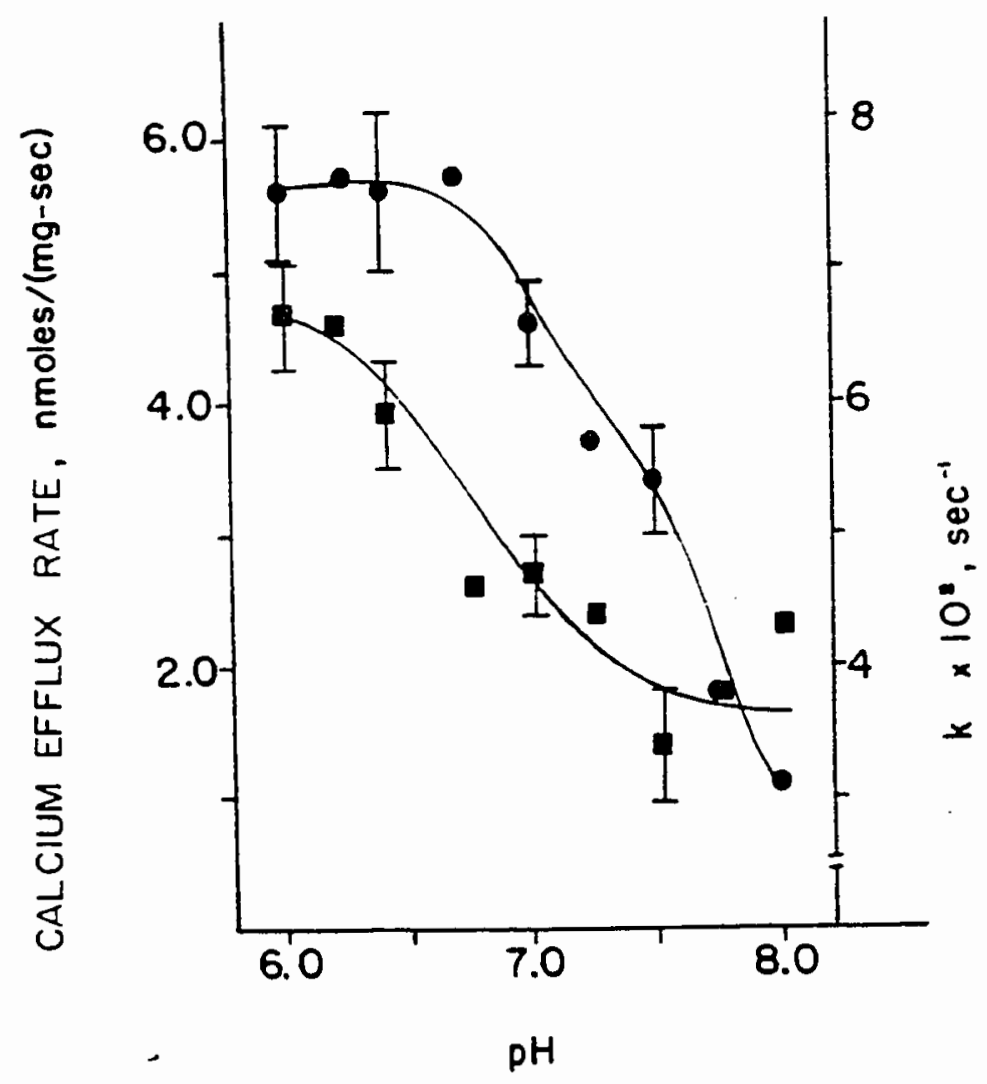

Figure 18.2 The $\mathrm{pH}$ dependence of rose bengalinduced $\mathrm{Ca}^{2}+$ efflux. SR vesicles were actively loaded as described in Figure 9 with the exception of the $\mathrm{pH}$. Buffers of various $\mathrm{pH}$ values ranging from $\mathrm{pH} 6.0$ to 8,0 were used. After accumulation of the added $\mathrm{Ca}^{2+}$, efflux was initiated by the addition of $5 \mu \mathrm{M}$ rose bengal in the semi-dark. The rate constant, $\mathbf{k}(\square)$, was calculated by dividing the maximal efflux rate ( ) by the total amount of $\mathrm{Ca}^{2+}$ released by rose bengal under these experimental conditions. Data with error bars represent experimental points run in triplicate. Data without error bars are data points run only once. 


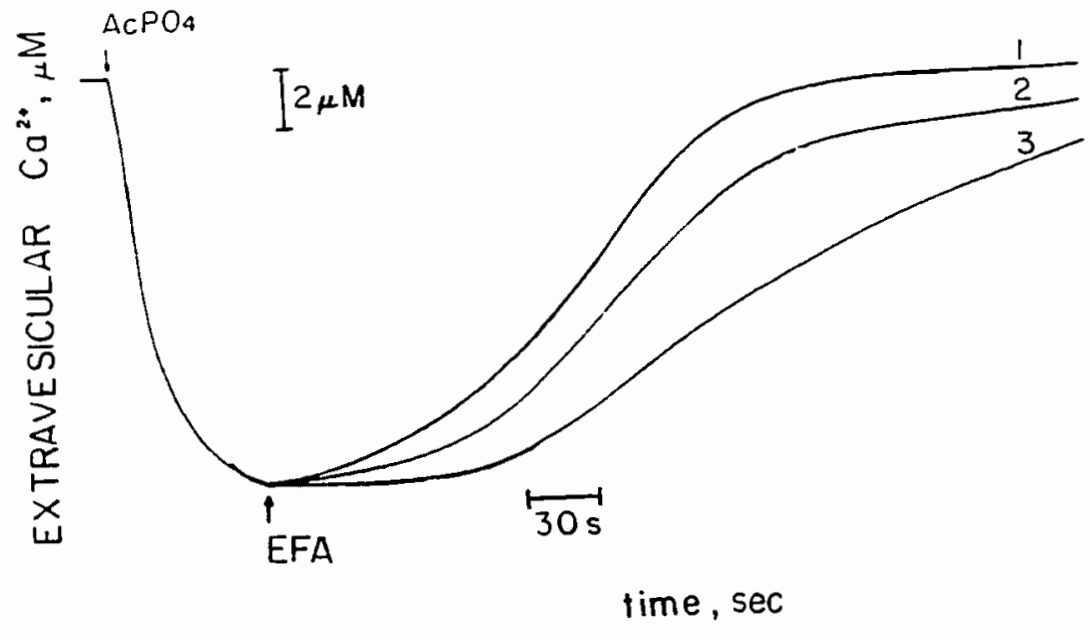

Figure 19. EFA stimulation of $\mathrm{Ca}^{2+}$ efflux from $S R$ vesicles. $\quad S R$ vesicles $(0.2 \mathrm{mg} / \mathrm{mL})$ were actively loaded with $\mathrm{Ca}^{2+}$ as described in Figure 9. After accumulation of the $\mathrm{Ca}^{2+}, 5 \mathrm{mM}$ (\#1), $1.0 \mathrm{mM}$ (\#2) or $0.5 \mathrm{mM}$ (\#3) EFA was added to initiate $\mathrm{Ca}^{2+}$ efflux. 
evidenced by the increased lag phase at increased $\mathrm{Mg}^{2+}$ concentrations. The EFA-induced $\mathrm{Ca}^{2+}$ efflux rates are $0.5,0.45$ and 0.3 nmoles/mg-sec in 1,3 or $6 \mathrm{mM} \mathrm{Mg}^{2+}$ buffer, respectively. These rates are the same within experimental error.

Table VII demonstrates that the maximal $\mathrm{Ca}^{2+}$ efflux rate induced by rose bengal or by EFA is $\mathrm{Mg}^{2+}$ independent, while $-\mathrm{SH}$ oxidation-induced $\mathrm{Ca}^{2+}$ release is strongly $\mathrm{Mg}^{2+}$ dependent. There is a lag phase between the addition of the effluxing reagent and release of the $\mathrm{Ca}^{2+}$ from the SR vesicles. The lag phase increases as the $\mathrm{Mg}^{2+}$ concentration increases (as indicated by the $t_{1 / 2}$ ); however, the maximal efflux remains constant. Unlike oxidation-induced $\mathrm{Ca}^{2+}$ efflux $(22,82,125)$, which is inhibited by increasing concentrations of $\mathrm{Mg}^{2+}$, rose bengal-induced $\mathrm{Ca}^{2+}$ efflux rates are not affected by external $\mathrm{Mg}^{2+}$ concentrations. The lag phase, however, does slightly increase with increasing $\mathrm{Mg}^{2+}$. The rose bengal interaction with histidine results in destruction of the imidazole ring, while EFA modifies one of the nitrogens in the inidazole ring. If the histidine (presumably the nitrogen) is part of the $\mathrm{Mg}^{2+}$ binding site, modification of the imidazole ring by EFA might also remove the $\mathrm{Mg}^{2+}$ dependence of $\mathrm{Ca}^{2+}$ efflux. As seen in Table VII, $\mathrm{Ca}^{2+}$ efflux following the modification of the SR with EFA is $\mathrm{Mg}^{2+}$ independent. However, as evidenced by the large 


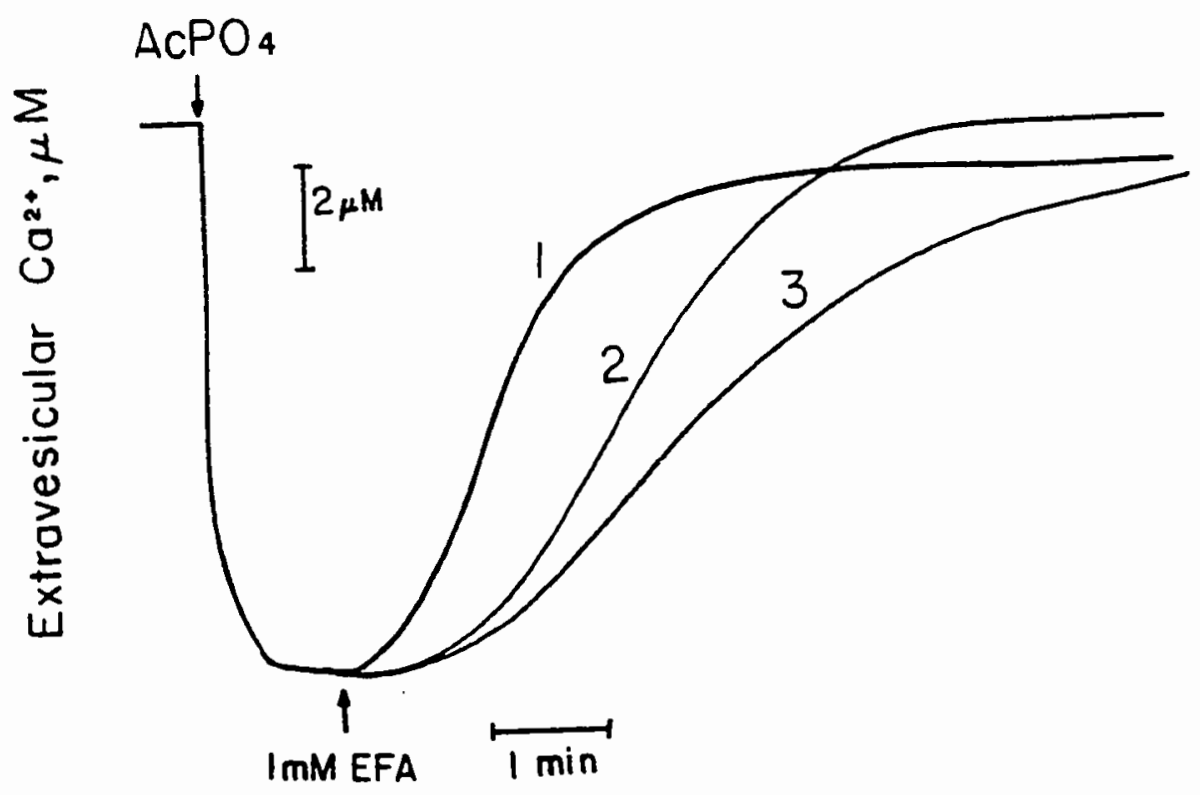

Time, minute

Fiqure 20. $\mathrm{Mg}^{2+}$ dependence of EFA-induced $\mathrm{Ca}^{2+}$ efflux. SR vesicles $(0.2 \mathrm{mg} / \mathrm{mL})$ were actively loaded with $\mathrm{Ca}^{2+}$ as described in Figure 9 with the exception of $\mathrm{Mg}^{2+}$ concentration. The $\mathrm{Mg}^{2+}$ concentration was varjed between 1) $1.0 \mathrm{mM}, 2$ ) $3.0 \mathrm{mM}$ and 3) $6.0 \mathrm{mM} \mathrm{\textrm {Mg } ^ { 2 }}$. 
TABLE VII

MAGNESIUM DEPENDENCE OF CALCIUM EFFLUX FROM ACTIVELY LOADED VESICLES

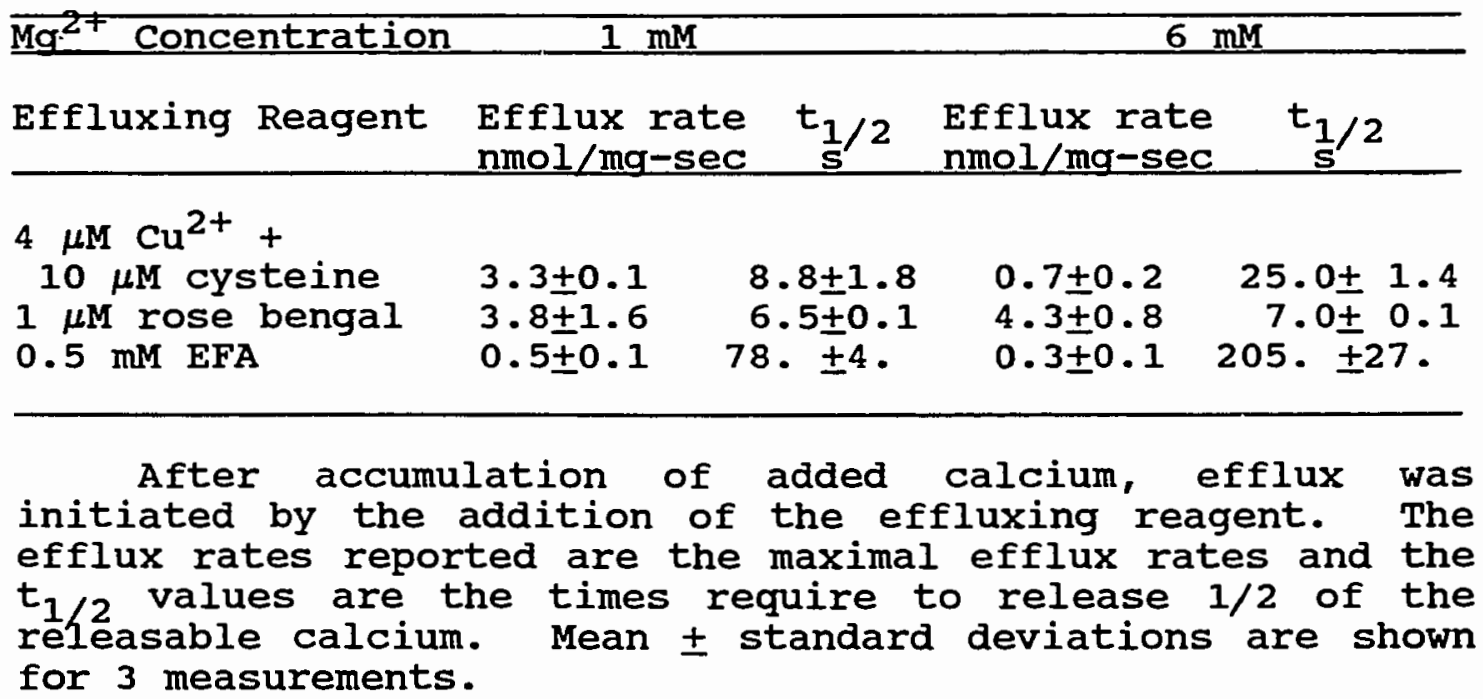


increase in the lag phase, the $S R$ is protected from EFA modification by the presence of increased concentrations of $\mathrm{Mg}^{2+}$. Therefore, a histidine may be part of the $\mathrm{Mg}^{2+}$ binding site.

It has been previously shown that the presence of adenine nucleotides stimulates oxidation-induced $\mathrm{Ca}^{2+}$ release $(81,83)$. Adenine nucleotides are also known to stimulate $\mathrm{Ca}^{2+}$-induced $\mathrm{Ca}^{2+}$ release $(68,123)$. It is known that histidines are often founa in nucleotide binding sites (127, 136-139) and are often involved in the active sites of enzymes (133-134). In chapter IV of this dissertation, it is shown that photooxidation of the SR is inhibited by $\mathrm{Mg}^{2+}$-AMP-PCP. To determine if the adenine nucleotide binding site associated with inhibition of photooxidationinduced $\mathrm{Ca}^{2+}$ release also contains a histidyl residue, histidine modification by EFA was monitored in the presence and absence of AMP-PCP.

similar to rose bengal-induced $\mathrm{Ca}^{2+}$ release, EFAinduced $\mathrm{Ca}^{2+}$ release is inhibited by adenine nucleotides. When EFA reacts with the imidazole group (histidyl residues) a chromophore (N-ethoxyformylimidazole) is formed. This chromophore absorbs strongly at $242 \mathrm{~nm}$ [ $\epsilon=$ $\left.3.2 \times 10^{3} \mathrm{M}^{-1} \mathrm{~cm}^{-1}(102)\right]$. Figure 21 shows that the rate of histidine modification induced by EFA is inhibited by AMP-PCP with a $\mathrm{K}_{\mathrm{I}}=50 \mu \mathrm{M}$. In the presence or absence of AMP-PCP, 78 or 124 nmoles histidine/mg SR protein are 


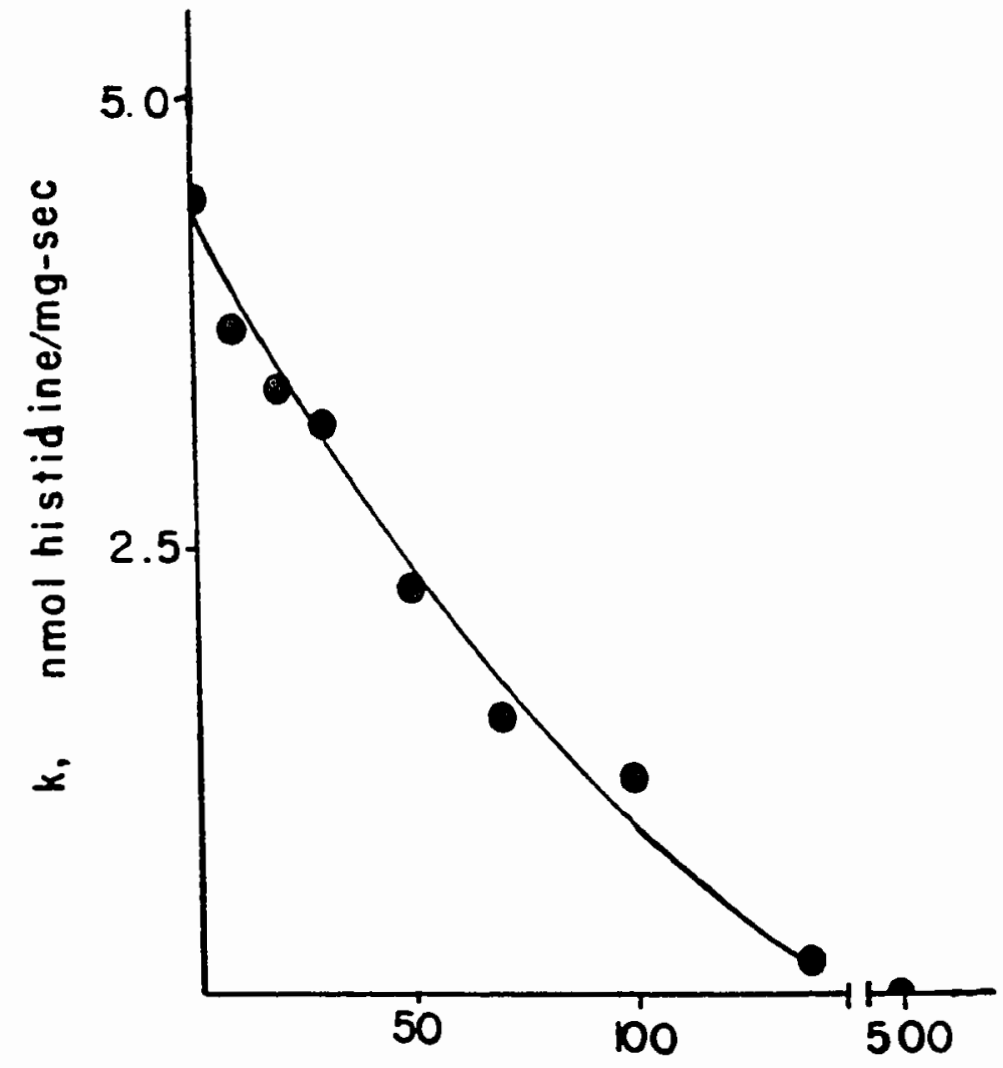

$[A M P-P C P], \mu M$

Figure 21. The effect of AMP-PCP concentration on the rate of histidine modification by EFA. SR vesicles, $(0.7 \mathrm{mg} / \mathrm{mL})$ were diluted into $100 \mathrm{mM}$ $\mathrm{KCl}$, $50 \mathrm{mM}$ Hepes, $\mathrm{pH} 7.0,1 \mathrm{mM}$ free $\mathrm{Mg}^{2+}$ buffer containing various concentrations of AMP-PCP. An absorbance baseline was established and $2.0 \mathrm{mM}$ EFA was added. The change in $\mathrm{Abs}_{242}$ was followed as a function of time. 
modified respectively. As can be seen in Figure 22, the rate of histidine modification unexpectedly shows saturation kinetics similar to an enzyme system even though the histidine residue is covalently modified. The modification has a $V \max =4.6$ nmoles histidine modified/mg-sec and a $\mathrm{Km}=4 \mathrm{mM}$. AMP-PCP inhibits modification of histidyl residues similar to noncompetitive inhibition in enzyme systems. The $\mathrm{Km}$ is not altered; however, the $\operatorname{Vmax}$ is decreased to 2.4 nmoles histidine modified/mg-sec. This seems to indicate that the EFA modification site is not on the adenine nucleotide binding site. However, AMP-PCP may induce a conformational change on a SR protein such that reactive histidines are less accessible.

\section{DISCUSSION}

It has previously been shown that oxidation of sulfhydryl groups on the $S R$ results in rapid release of internal $\mathrm{Ca}^{2+}(22,82,83,114,125)$. This effect is stimulated by adenine nucleotides $(81,83)$ and inhibited by $\mathrm{Mg}^{2+}(22,82,83,114,125)$. In Chapter IV, the photooxidation of the SR by micromolar concentrations of rose bengal is discussed. Unlike -SH oxidation, photooxidation-induced $\mathrm{Ca}^{2+}$ release shows no $\mathrm{Mg}^{2+}$ dependence and is inhibited by adenine nucleotides. In this Chapter, it is shown that modification of the SR with 

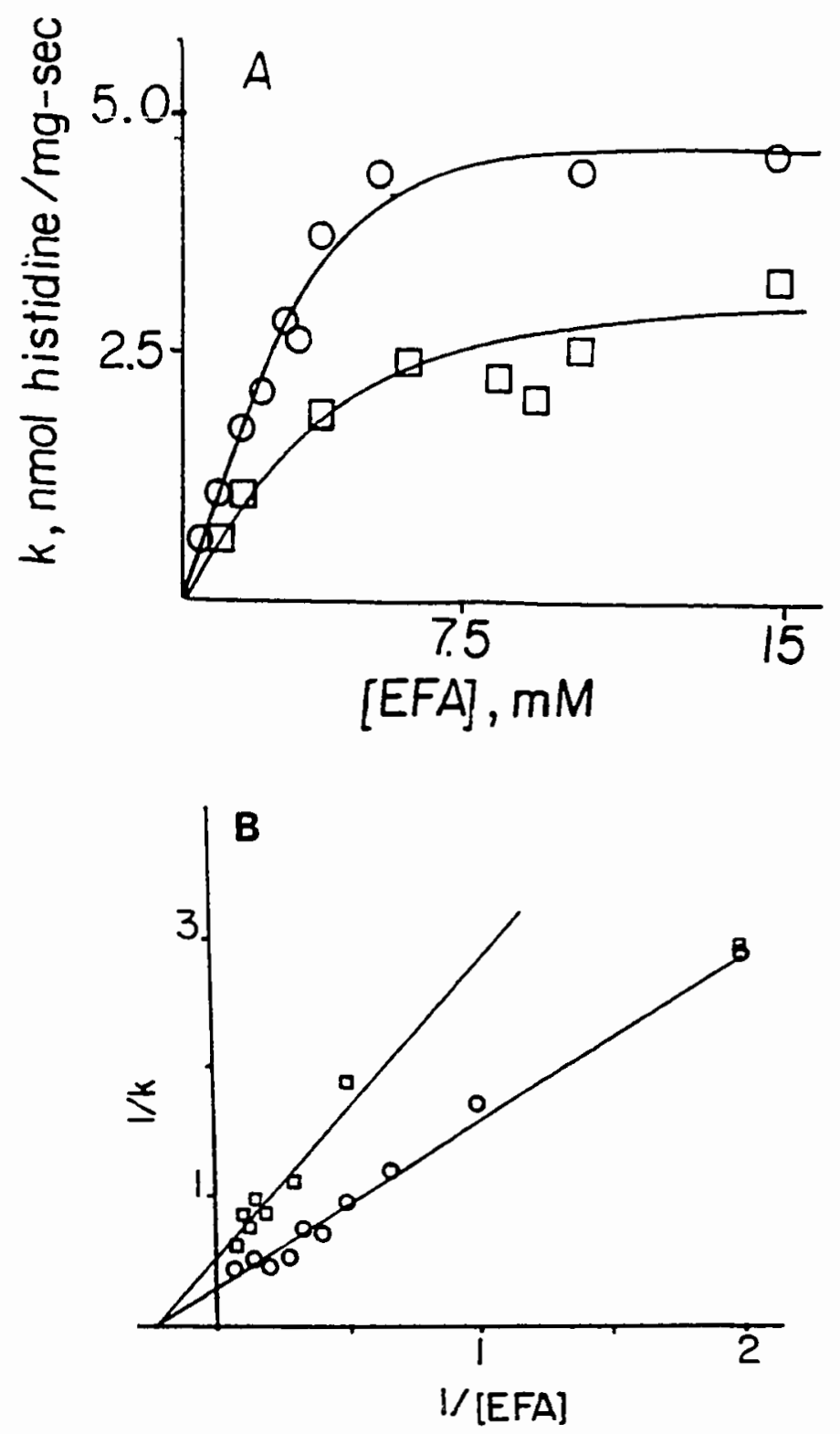

Figure 22. The concentration dependence of EFA modification of histidyl residues. SR vesicles were diluted as described in Figure 21 in the presence $(\square)$ or absence $(O)$ of $50 \mu \mathrm{M}$ AMPPCP. Various concentrations of EFA were added and the change in $\mathrm{Abs}_{242}$ was followed as $a$ function of time. (A) The rate as a function of EFA concentration. (B) A Lineweaver-Burk plot of the data. The $K_{M}=4.0$ or $3.9 \mathrm{mM}$ in the absence or presence of AMP-PCP respectively. The $v_{\max }=3.2$ or 1.7 nmoles histidine modified/mgsec in the absence or presence of AMP-PCP respectively. 
millinolar concentrations of EFA, a histidine specific reagent, induces $\mathrm{Ca}^{2+}$ efflux from SR vesicles. The maximal EFA-induced $\mathrm{Ca}^{2+}$ efflux rates are $\mathrm{Mg}^{2+}$ independent and are inhibited by ATP.

Millimolar concentrations of $\mathrm{Mg}^{2+}$ inhibit $\mathrm{Ca}^{2+}$ efflux rates triggered by various known stimulators of $\mathrm{Ca}^{2+}$ release by binding to the $\mathrm{Ca}^{2+}$ activator site. Increasing $\mathrm{Mg}^{2+}$ affects both the $\mathrm{t}_{1 / 2}$ and the $\mathrm{Ca}^{2+}$ efflux rate of $-\mathrm{SH}$ oxidation induced $\mathrm{Ca}^{2+}$ release (Table VII). Photooxidation-induced maximal $\mathrm{Ca}^{2+}$ efflux rates are $\mathrm{Mg}^{2+}$ independent. Nevertheless, there is some lengthening of the lag phase (the period between the addition of efflux reagent and the initiation of $\mathrm{Ca}^{2+}$ release) with increased $\mathrm{Mg}^{2+}$. While this lag phase is only slightly modified by increasing $\mathrm{Mg}^{2+}$ concentrations when release is triggered by rose bengal, EFA-induced $\mathrm{Ca}^{2+}$ release is much more dramatically affected by $\mathrm{Mg}^{2+}$. Table VII shows an approximately 3 -fold increase in $t_{1 / 2}$ and $a$ constant maximal efflux rate when EFA is used to induce $\mathrm{Ca}^{2+}$ efflux at $6 \mathrm{mM} \mathrm{Mg}^{2+}$ compared to values obtained at $1 \mathrm{mM} \mathrm{Mg}^{2+}$. The $\mathrm{Ca}^{2+}$ dependence of the $\mathrm{Ca}^{2+}$ release rate triggered by rose bengal (Chapter IV) is also considerably different than release triggered by adenine nucleotides $(68,70)$, or via sulhydryl oxidation (83). This altered $\mathrm{Mg}^{2+}$ and $\mathrm{Ca}^{2+}$ dependence may be caused by: 1) the $\mathrm{Mg}^{2+/} \mathrm{Ca}^{2+}$ binding site(s) may contain a histidyl residue, which is being 
modified by rose bengal and EFA; 2) histidine modification alters the normal gating mechanism of the $\mathrm{Ca}^{2+}$ release protein so dramatically that it no longer responds to $\mathrm{Mg}^{2+}$ or 3) $\mathrm{Ca}^{2+}$ release induced by histidine modification is directed toward a SR transport protein other than the $\mathrm{Ca}^{2+}$ release protein.

It is known that histidines are present in ATP and NAD binding sites in soluble enzymes (127, 136-139). Figure 22 shows that EFA modification of the SR has Michaelis-Menten type kinetics with a Vmax $=4.6$ nmoles histidine modified/mg-sec and $a K_{M}=4.0 \mathrm{mM}$. In the presence of 50 $\mu M$ AMP-PCP, the $\operatorname{Vmax}$ and $K_{M}$ of EFA modification are 2.4 nmoles histidine modified/mg-second and $3.9 \mathrm{mM}$ respectively, indicating the AMP-PCP inhibition is noncompetitive. The $\mathrm{K}_{I}$ for ATP inhibition of EFA-induced $\mathrm{Ca}^{2+}$ release is $50 \mu \mathrm{M}$. These data suggest there is a histidyl residue, which may be part of the $\mathrm{Mg}^{2+}$ binding site, in close proximity to the ATP binding site associated with the $\mathrm{Ca}^{2+}$ release protein. Tenu et al. (87) reported that histidine modification of the SR (using EFA) was not in the ATP binding site on the $\mathrm{Ca}^{2+}, \mathrm{Mg}^{2+}$-ATPase, but that histidine modification induces a conformational change resulting in altered ATP binding.

known modulators of $\mathrm{Ca}^{2+}$ release $(10,57,68,123)$ affect rose bengal-stimulated $\mathrm{Ca}^{2+}$ release or EFA-induced $\mathrm{Ca}^{2+}$ release differently than previously observed for $\mathrm{Ca}^{2+}$ 
induced or oxidation-induced $\mathrm{Ca}^{2+}$ release. This altered response could be due to a disruption of communication between the gating mechanism and the modulatory site. Alternatively, the mechanism by which rose bengal/EFA stimulates $\mathrm{Ca}^{2+}$ release may involve a totally different molecular interaction with the ion transport systems of the SR.

The $\mathrm{pH}$ profile of the $\mathrm{Ca}^{2+}$ efflux rate induced by photooxidation is unusual (Figure 18). Yu et al. (88) showed that the inhibition of $\mathrm{Ca}^{2+}, \mathrm{Mg}^{2+}$-ATPase activity by rose bengal followed a more typical $\mathrm{pH}$ dependence. The $\mathrm{pH}$ dependence they observed was similar to a titration curve for a monoprotic amino acid with a $\mathrm{pk}_{\mathrm{a}}$ around 7.0. The modification of the histidine in the $\mathrm{Ca}^{2+}, \mathrm{Mg}^{2+}$-ATPase was more reactive in the unprotonated form. Rose bengalinduced $\mathrm{Ca}^{2+}$ efflux rate decreases with an increase in $\mathrm{pH}$ suggesting that the most reactive form of this histidine is the protonated species. The pK may be altered by the secondary and tertiary protein structure surrounding the histidyl residue. Trimm et al. (22) showed that pH dependence of $-\mathrm{SH}$ oxidation-induced $\mathrm{Ca}^{2+}$ release is optimal at $\mathrm{pH}$ 7.0. The efflux rate decreases above and below $\mathrm{pH}$ 7.0. Brockelhurst $(133-134)$ reports two models that generate $\mathrm{pH}$ profiles similar to the one reported in this study. The reaction center he describes contains either two reactive protonic and one unreactive protonic state or 
a three reactive protonic state. The $\mathrm{pH}$ profiles modeled by Brockelhurst are for a two amino acid ion pair and cover the $\mathrm{pH}$ range from 4-10. The $\mathrm{pH}$ profile observed in Figure 18 covers a $\mathrm{pH}$ range from 6-8. It is, therefore, not possible to determine which of these two models best fits the data presented here. However, the pH profile of rose bengal-induced $\mathrm{Ca}^{2+}$ release suggests that a reactive histidine may form an ion pair, possibly with the reactive cysteine described by Trimm et al. (22), if histidine modification occurs on the $\mathrm{Ca}^{2+}$ release channel. Cysteinehistidine ion pairs are reported in soluble enzymes (133134, 137-138). Papain a has cysteine/histidine ion pair (133-135) and shows a pH profile (135) similar to the one observed here.

The theory that the photooxidation site on the SR is a histidyl residue is further supported by the fact that excess histidine in the effluxing buffer decreases $\mathrm{Ca}^{2+}$ efflux rates induced by rose bengal by $\sim 40 \%$ Cysteine or lysine in the reaction buffer have no effect on the release rates. Also, when SR residues are photooxidized in the presence of rose bengal for 1 minute, a strong absorbance maximum appears at $-250 \mathrm{~nm}$ which is attributed to the photooxidation of histidine. At longer illumination times a second absorbance maximum appears at $-306 \mathrm{~nm}$ with a depressed absorbance at $290 \mathrm{~nm}$. Photooxidation of a solution of $5 \mathrm{mM}$ histidine or tryptophan shows an $\lambda_{\max }-233$ 
$\mathrm{nm}$ or $-301 \mathrm{~nm}$, respectively. The photooxidation of $5 \mathrm{~mm}$ lysine or methionine does not produce an increased absorbance between 220 and $320 \mathrm{~nm}$. The photooxidation of cysteine produces a valley around $240 \mathrm{~nm}$ presumably from the production of cystine. The peak observed at $\sim 250 \mathrm{~nm}$ when the SR is photooxidized is likely due to the photooxidation of histidyl residues. The red shift is likely to be due to the microenvironment in which the histidine resides. The peak at $-306 \mathrm{~nm}$ appears after significantly longer illumination time indicating that slow photooxidation of tryptophan may also occur. since photooxidation-induced $\mathrm{Ca}^{2+}$ efflux is essentially complete within 30 seconds, it is unlikely that the oxidation of the tryptophanyl residues is responsible for inducing rapid $\mathrm{Ca}^{2+}$ efflux. It is likely that the photooxidation target on the $\mathrm{SR}$ is a histidyl residue. 
CHAPTER VI

SUMMARY AND PROJECTIONS

The work in this thesis was inspired in part by the research of Dr. Jonathan Trimm (22). He showed that the addition of micromolar concentrations of $\mathrm{Cu}^{2+}$ and cysteine to $S R$ vesicles actively loaded with $\mathrm{Ca}^{2+}$ resulted in the rapid efflux of the accumulated $\mathrm{Ca}^{2+}$. When these experiments were repeated with passively loaded vesicles (i.e. in the absence of ATP) the $\mathrm{Ca}^{2+}$ efflux rates were significantly slower. Also $\mathrm{Cu}^{2+} /$ cysteine-induced $\mathrm{Ca}^{2+}$ efflux rates from vesicles actively loaded with $\mathrm{Ca}^{2+}$ using $\mathrm{ACPO}_{4}$ as substrate were approximately $4 \mathrm{x}$ less sensitive to $\mathrm{Cu}^{2+} /$ cysteine than were vesicles actively loaded using ATP. This suggested that ATP stimulates oxidation-induced $\mathrm{Ca}^{2+}$ efflux.

Subsequently, it was shown that adenine nucleotides did, in fact, stimulate oxidation-induced as well as heavy metal-induced $\mathrm{Ca}^{2+}$ efflux with an order of effectiveness as follows:

$$
\text { ATP > AMP-PCP > CAMP > AMP > adenine }
$$

The relative effectiveness of these different adenine containing nucleotides in stimulating oxidation-induced $\mathrm{Ca}^{2+}$ releases is the same as in stimulating $\mathrm{Ca}^{2+}$-induced 
release (68). The stimulatory effect is synergistic, indicating that the $\mathrm{ATP}$ and $\mathrm{Cu}^{2+} /$ cysteine are also affecting two distinct tightly coupled sites. Oxidationinduced $\mathrm{Ca}^{2+}$ efflux is strongly inhibited by high external $\mathrm{Mg}^{2+}$ but only slightly inhibited by high internal $\mathrm{Mg}^{2+}$. The $\mathrm{Mg}^{2+}$ on the myoplasmic face of the SR is a much more potent inhibitor of $\mathrm{Ca}^{2+}$ release activity than $\mathrm{Mg}^{2}$ on the lumenal face. As a result of this study (81), it was concluded that $\mathrm{Mg}^{2+}$ binding to a site on the myoplasmic face of the $S R$ results in closing of the $-S H$ oxidation gating mechanism. Perhaps even more significant was the finding that both $\mathrm{Ca}^{2+}$-induced and oxidation-induced $\mathrm{Ca}^{2+}$ release are stimulated in an almost identical fashion by adenine containing nucleotides. It appears as if a common SR protein component is triggered by both methods of stimulating $\mathrm{Ca}^{2+}$ release.

oxidation-induced $\mathrm{Ca}^{2+}$ release shows an unusual $\mathrm{pH}$ dependence (22). The optimal $\mathrm{pH}$ of the reaction is 7.0 unlike a free uncomplexed cysteine which has a pK 8.3 (13). This unusual $\mathrm{pH}$ dependence led me to hypothesize that another amino acid may be influencing the reactive thiol. Since histidine is known to hydrogen bond to cysteine in soluble proteins (133-135) and histidyl residues are found in the adenine nucleotide binding sties of some enzymes (136-139), it seemed possible that a histidine could be located in close proximity to the reactive thiol. If the 
reaction site did contain a cysteine complexed to a histidine, the oxidation of this histidyl residue might alter the reactivity of the thiol and/or the ATP stimulatory effect.

Using photooxidation and covalent modification techniques, the modification of histidyl residues has been shown to increase the $\mathrm{Ca}^{2+}$ permeability of $\mathrm{SR}$ vesicles. Rose bengal, a halogen substituted xanthene dye, induces rapid $\mathrm{Ca}^{2+}$ efflux from $\mathrm{SR}$ vesicles. At concentrations below $3 \mu \mathrm{M}$ the reaction requires irradiation while above 3 $\mu \mathrm{M}$ the reaction proceeds in the absence of light. Unlike oxidation-induced $\mathrm{Ca}^{2+}$ release, rose bengal-induced $\mathrm{Ca}^{2+}$ release is $\mathrm{Mg}^{2+}$ independent. It is also inhibited by ATP and is only partially inhibited by ruthenium red. Rose bengal-induced $\mathrm{Ca}^{2+}$ release is only partially selective for the SR derived from the terminal cisternae (HSR). Nonspecific oxidation of membrane lipids is not responsible for the photooxidation stimulation of $\mathrm{Ca}^{2+}$ release observed in SR vesicles. Yet, LSR vesicles which are presumably devoid of the $\mathrm{Ca}^{2+}$ release channel respond to stimulation by rose bengal. HSR is 40\% more sensitive to rose bengal than is LSR. The photooxidation target present in the ISR may be a ruthenium red insensitive $\mathrm{Ca}^{2+}$ channel or some other transport system which has been modified such that it now transports $\mathrm{Ca}^{2+}$. The data, discussed in chapter IV, provide a foundation for the study of photooxidation- 
induced ion permeability in the SR. It is also of environmental significance because xanthene dyes are used in cosmetics, medical procedures and until recently were used as food colorings. The results shown in chapter IV indicate that these dyes are not benign and nontoxic but that they can oxidize a biological membrane whose function is critical for normal muscle function.

EFA, a histidine modifying reagent, induces $\mathrm{Ca}^{2+}$ efflux from $S R$ vesicles. The histidine modification results in the production of a chromophore with a strong absorbance at $242 \mathrm{~nm}$. By following the change in $\mathrm{Abs}_{242}$, it was observed that histidine modification by EFA followed kinetics similar to saturation kinetics found in enzyme systems with a $K_{M}=4.0 \mathrm{mM}$ and a $V_{\max }=4.6$ nmoles histidine modified/mg-sec. The $K_{M}$ in the presence or absence of AMP-PCP remained the same, however the $\mathrm{V}_{\max }$ decreased to 2.4 nmoles histidine modified/mg-sec in the presence of $50 \mu \mathrm{M}$ AMP-PCP. The inhibition of EFA-induced $\mathrm{Ca}^{2+}$ efflux rates by AMP-PCP are the result of AMP-PCP affecting the reaction rate of histidine modification, not the rate of release subsequent to modification. The inhibition of EFA modification by AMP-PCP is similar to non-competitive inhibition observed in enzyme kinetics suggesting that the reactive histidine(s) is(are) near to but is(are) not part of the ATP binding site. 
Rose bengal-induced and EFA-induced maximal $\mathrm{Ca}^{2+}$ efflux rates are $\mathrm{Mg}^{2+}$ independent. However, as the $\mathrm{Mg}^{2+}$ concentration increased, EFA-induced $\mathrm{Ca}^{2+}$ efflux showed a lengthening of the lag phase (i. e., the time between the addition of the effluxing reagent and the beginning of the efflux). This suggests that $\mathrm{Mg}^{2+}$ affords some protective effect to the SR against histidine modification by EFA. The rate of histidine modification, as measured by the production of the chromophore, is also $\mathrm{Mg}^{2+}$ independent and shows a similar increased time lag associated with increased $\mathrm{Mg}^{2+}$ concentration. These data, discussed in Chapter V, show that ATP affects the rate of histidine modification in a non-competitive fashion and $\mathrm{Mg}^{2+}$ somehow protects the SR from modification by EFA and rose bengal. ATP and $\mathrm{Mg}^{2+}$ also affect the $\mathrm{Ca}^{2+}$ release process. The reactive histidine may be in or close to a $\mathrm{Mg}^{2+}$ binding site and is affected by the binding of ATP to the SR.

Photooxidation-induced and EFA-induced $\mathrm{Ca}^{2+}$ release react differently to known modulators of $\mathrm{Ca}^{2+}$ release than does either $\mathrm{Ca}^{2+}$-induced or oxidation-induced $\mathrm{Ca}^{2+}$ release. The modification of histidyl residues may alter the $\mathrm{Ca}^{2+}$ release system such that it is no longer responsive to known modulators. Alternatively, the histidine modification effect may be on a completely different protein. Photooxidation-induced $\mathrm{Ca}^{2+}$ is more effective in HSR than in LSR. The increased reactivity of the HSR may be due to 
a reactive component which is found more in HSR than in ISR. This reactive component may be the $\mathrm{Ca}^{2+}$ release channel. It is also possible that the increased sensitivity of HSR to photooxidation is the result of the modification of several different types of channels. These channels may or may not include the $\mathrm{Ca}^{2+}$ release protein.

According to Meissner (11), in addition to the $\mathrm{Ca}^{2+}$ release pathway, the SR contains two or three independent ion channels: 1) a $\mathrm{K}^{+}, \mathrm{Na}^{+}$channel, 2) an anion channel and 3) a $\mathrm{H}^{+}$channel. The $\mathrm{H}^{+}$channel may be the same as the anion channel. The $\mathrm{K}^{+}$channel is inhibited by $\mathrm{Ag}^{+}$with a $\mathrm{K}_{\mathrm{I}}=0.4 \mu \mathrm{M}(140)$. Cesium and $\mathrm{Ca}^{2+}$ also inhibit the potassium channel by binding to the cis side (corresponding to the myoplasmic side) of the lipid bilayer (141-142). Bis-quarternary ammonium compounds inhibit the $\mathrm{K}^{+}$ conductance when added to the trans (corresponding to the lumen side of the membrane) side of the lipid bilayer (143146).

It is of interest to determine whether the rose bengal-induced $\mathrm{Ca}^{2+}$ release is through a $\mathrm{K}^{+}$channel altered so dramatically that it now conducts $\mathrm{Ca}^{2+}$. As can be seen in Figure 23, the rose bengal-induced $\mathrm{Ca}^{2+}$ release is not inhibited in the presence of $\mathrm{Cs}^{+}$ions. $\mathrm{Ag}^{+}$is known to induce $\mathrm{Ca}^{2+}$ release from $\mathrm{SR}$ vesicles with a specificity of HSR over ISR (114). Silver-induced $\mathrm{Ca}^{2+}$ release is also strongly $\mathrm{Mg}^{2+}$ dependent. In order to minimize $\mathrm{Ca}^{2+}$ 
transport through the $\mathrm{Ca}^{2+}$ release protein, $\mathrm{Ca}^{2+}$ release was assayed using LSR vesicles in the presence of high $\mathrm{Mg}^{2+}$. No $\mathrm{Ca}^{2+}$ was released by the addition of $0.5 \mu \mathrm{M}$ silver and rose bengal-induced (10 $\mu \mathrm{M}$ rose bengal) $\mathrm{Ca}^{2+}$ release rates were not significantly altered by pretreatment with sufficient $\mathrm{Ag}^{+}$to presumable close down the $\mathrm{K}^{+}$channels from SR (Table VIII). These results (Cs ${ }^{+}$ and $\mathrm{Ag}^{+}$effects) do not, however, conclusively rule out the involvement of the $\mathrm{K}^{+}$channel in the observed rose bengal-induced $\mathrm{Ca}^{2+}$ release. Although $\mathrm{Ag}^{+}$and $\mathrm{Cs}^{+}$are known to inhibit an unmodified $\mathrm{K}^{+}$channel they may not inhibit the $\mathrm{K}^{+}$channel subsequent to rose bengal modification of the channel.

Kasai (145) reports that the anion channel found in the SR is similar to the anion channel in red blood cells. Both channels are inhibited by DIDS $\left(4,4^{\prime}\right.$-diisothiocyanostilbene-2,2' disulfonic acid) and SITS (4-acetoamido-4'isothiocyano-2,2'-stilbene-disulfonic acid) which apparently bind to the myo(cyto)plasmic side of the membrane. It has been reported (148-149) that photooxidation, using eosin thiocyanate as sensitizer, of the anion channel in red blood cells increases the cation permeability of the red blood cell. SR vesicles treated with $25 \mu M$ DIDS are still sensitive to photooxidation resulting in rapid release of accumulated $\mathrm{Ca}^{2+}$. Table IX shows that incubation of the SR with DIDS for either 1 


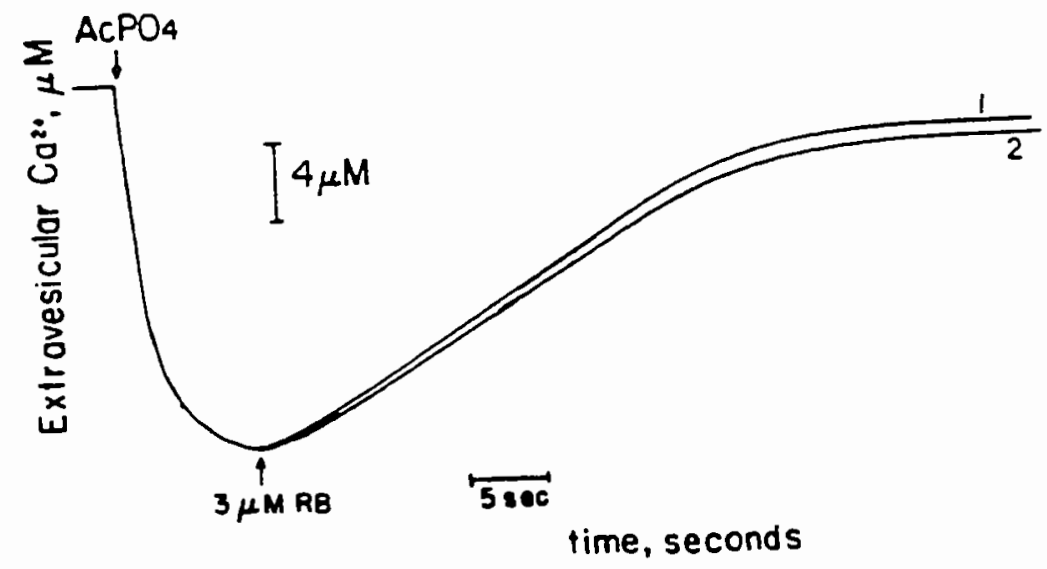

Figure 23. The effect of $\mathrm{Cs}^{+}$ions on photooxidation-induced $\mathrm{Ca}^{2+}$ release. $\mathrm{SR}$ vesicles were actively loaded with $\mathrm{Ca}^{2+}$ as described in Figure 9 either in $100 \mathrm{mM} \mathrm{KCl} \mathrm{(1)} \mathrm{or} 100 \mathrm{mM} \mathrm{CsCl}$ (2). 


\section{TABLE VIII}

THE EFFECT OF SILVER ON PHOTOOXIDATION-INDUCED $\mathrm{Ca}^{2+}$ RELEASE FROM LSR VESICLES

LSR vesicles were actively loaded as described in Figure 9 in the presence of APIII and $6 \mathrm{mM} \mathrm{Mg}^{2+}$. After accumulation of the added $\mathrm{Ca}^{2+}, 0.5 \mu \mathrm{M} \mathrm{Ag} \mathrm{Al}^{+}$was added. $\mathrm{Ca}^{\frac{1}{2}+}$ efflux. Controls in the absence of $\mathrm{Ag}^{+}$were run. 
TABLE IX

THE EFFECT OF DIDS ON PHOTOOXIDATION-INDUCED $\mathrm{Ca}^{2+}$ RELEASE FROM SR VESICLES

EFFLUXING CONDITION

EFFLUX RATE nmoles/mg-sec

Pretreated with DIDS

1 minute

60 minute

Untreated

1 minute

60 minute

$$
\begin{aligned}
& 1.8 \pm .1 \\
& 1.4 \pm .2 \\
& 1.7 \pm .02 \\
& 1.6 \pm .1
\end{aligned}
$$

SR vesicles were preincubated for 1 or 60 minutes in the presence or absence of $25 \mu \mathrm{M}$ DIDS. SR vesicles were then actively loaded as described in Figure 9. After accumulation of the added $\mathrm{Ca}^{2+}, 1_{2} \mu \mathrm{M}$ rose bengal plus illumination was added to initiate $\mathrm{Ca}^{2+}$ efflux. 
minute or 1 hour does not affect photooxidation-induced $\mathrm{Ca}^{2+}$ efflux rates.

Currently the participation of the $\mathrm{K}^{+} / \mathrm{Cl}^{-}$channel(s) in rose bengal-induced $\mathrm{Ca}^{2+}$ efflux is being studied in our laboratory using planar bilayer and single channel techniques. Hopefully these studies will lend some information regarding the characteristics of ion channels in the SR membrane.

Crosslinking of membrane proteins is a valuable tool to study the arrangement of proteins within the membrane. Figure 24 shows the crosslinking of SR membrane proteins at various times of illumination in the presence (Figure 24b) or absence (Figure $24 \mathrm{a}$ ) of lysine. $3 \mu \mathrm{M}$ rose bengal plus illumination results in the disappearance of minor SR membrane proteins on SDS-PAGE after 30 seconds of illumination (Figure 24, lane 8). After 5 minutes illumination in the presence of $3 \mu \mathrm{M}$ rose bengal (lane 6) the majority of SR proteins are crosslinked. There is also an apparent loss of density in the protein band corresponding to $-91 \mathrm{~K}$ daltons. In addition there is an increase of proteins in the high molecular weight region of the gel. The presence of the lysine did not totally prevent the crosslinking observed here. The crosslinking of the proteins under these condition, therefore, likely either proceeds by some mechanism other than aldehyde/amine 
A

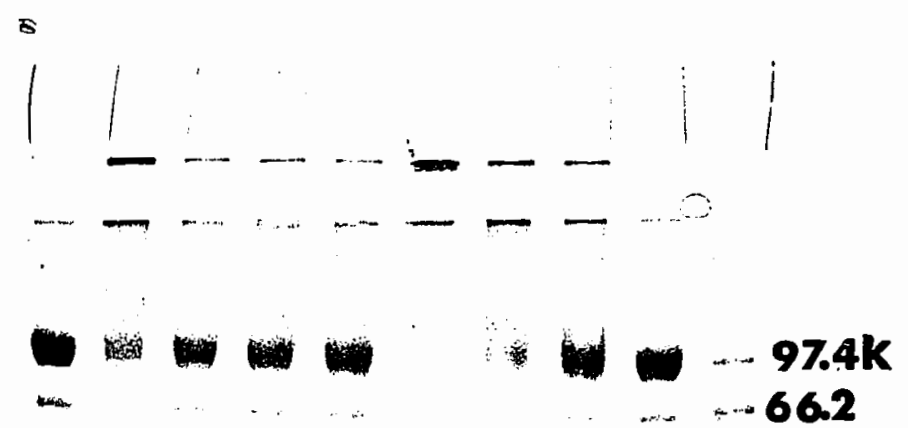

31.0

21.5

\section{$\begin{array}{llllllllll}1 & 2 & 3 & 4 & 5 & 6 & 7 & 8 & 9 & 10\end{array}$}

Figure 24. The effect of photooxidation on SDSPAGE pattern of $S R$ proteins. $1.0 \mathrm{mg} / \mathrm{ml} \mathrm{SR}$ vesicles were treated with $3 \mu \mathrm{M}$ rose bengal and illuminated for 30 seconds (lane 8), 1 minute (lane 7) or 5 .minutes (lane 6 ). SR vesicles were also incubated with $10 \mu \mathrm{M}$ rose bengal in the dark for 30 seconds (lane 5), 1 minute (lane 4) or 5 minutes (lane 3). SR vesicles treated with $100 \mathrm{nM}$ rose bengal for 5 minutes are shown in lane 2 . Lanes 1 and 9 are SR vesicles in the absence of rose bengal, treated with 5 or 0 minutes of irradiation, respectively. Lane 10 shows known molecular weight markers. The treatment of SR vesicles was done in the presence (B) or absence of (A) $40 \mathrm{mM}$ lysine. After treatment of the $S R$, the vesicles were diluted into sample buffer to stop the reaction. SDS-PAGE was run according to the procedure described in chapter II. 
B
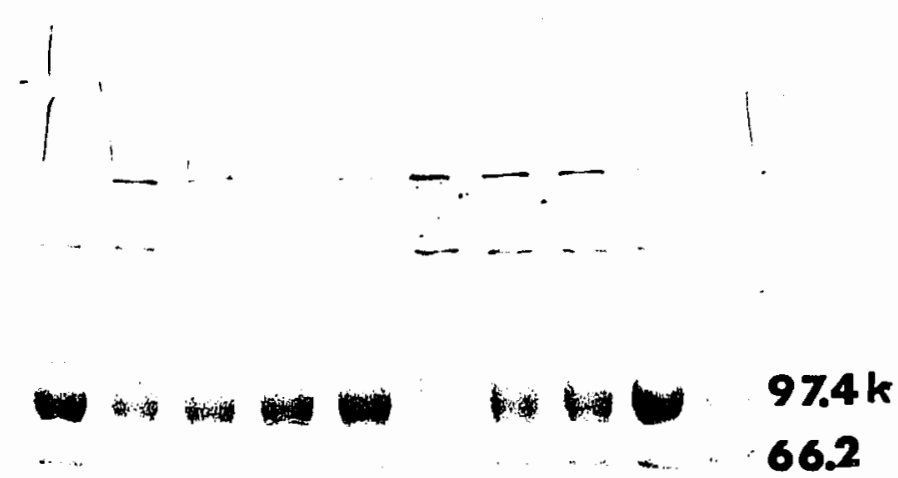

31.0

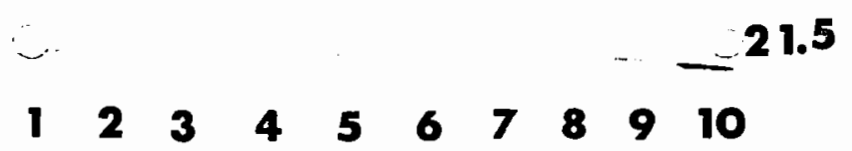

Figure 24B. The effect of photooxidation on SDSPAGE pattern of SR proteins. 
condensation or the added lysine is not accessible to the modified histidine. Photooxidation of the SR for 5 minutes with $100 \mathrm{nM}$ rose bengal also results in the disappearance of the same minor component. Crosslinking of these minor components could possibly contribute to the increased $\mathrm{Ca}^{2+}$ permeability of $S R$ vesicles upon photooxidation.

The increased $\mathrm{Ca}^{2+}$ permeability observed in the dark reaction of rose bengal-induced $\mathrm{Ca}^{2+}$ efflux experiments probably is not due to crosslinking of proteins. When SR vesicles are treated with $10 \mu \mathrm{M}$ rose bengal in the dark there is a rapid efflux of internal $\mathrm{Ca}^{2+}$. Essentially all of the $\mathrm{Ca}^{2+}$ has effluxed from the vesicles under these conditions within 30 seconds yet there is very little observable crosslinking of membrane proteins when SR vesicles were incubated with $10 \mu \mathrm{M}$ rose bengal for as long as 5 minutes. $\mathrm{Ca}^{2+}$ efflux from vesicles treated with $10 \mu \mathrm{M}$ rose bengal in the dark is not likely to be the result of crosslinking of membrane proteins.

Pooler et al. (115-118) has been able to label proteins of the red blood cell membrane using a xanthene derivatized dye, Eosin maleimide. In Figure 25, it is shown that the xanthene dyes, Eosin B and Erythrosin B are able to induce $\mathrm{Ca}^{2+}$ release from actively loaded SR vesicles. The effect seen with these two dyes is significantly slower than the effect seen with rose bengal. The increased efficiency of rose bengal as a 
photooxidizable sensitizer is related to its ability to partition into bilayers. Pooler et al. (117-118) reported that the efficiency of Eosin B to photooxidize the anion channel of red blood cells increased dramatically when it (Eosin B) was derivatized with maleimide. Eosin B and Eosin B maleimide are both capable of producing singlet oxygen with the same efficiency. The increased effect that Pooler et al. (117-118) reported was probably due to the covalent binding of the maleimide to a membrane component. It may be prssible to label $S R$ membrane proteins with the Eosin maleimide (which has a very high fluoresence) and follow the crosslinking pattern of SR membrane proteins. This type of experiment could provide valuable information regarding the arrangement of the $S R$ membrane proteins.

In conclusion, the data in this thesis provide new and valuable information describing the $\mathrm{Ca}^{2+}$ release pathway of SR vesicles. Oxidation-induced $\mathrm{Ca}^{2+}$ efflux is synergistically stimulated by ATP and is inhibited by $\mathrm{Mg}^{2+}$ binding to an inhibitory site on the myoplasmic face of the membrane. The similarities between $\mathrm{Ca}^{2+}$-induced and oxidation-induced $\mathrm{Ca}^{2+}$ release are striking. It appears as if the reactive thiol may be in close proximity to the, as yet, undefined $\mathrm{Ca}^{2+}$ binding site responsible for triggering $\mathrm{Ca}^{2+}$-induced $\mathrm{Ca}^{2+}$ release. Perhaps the binding of $\mathrm{Ca}^{2+}$ is the first of a series of steps that results in the oxidation of a reactive thiol. 


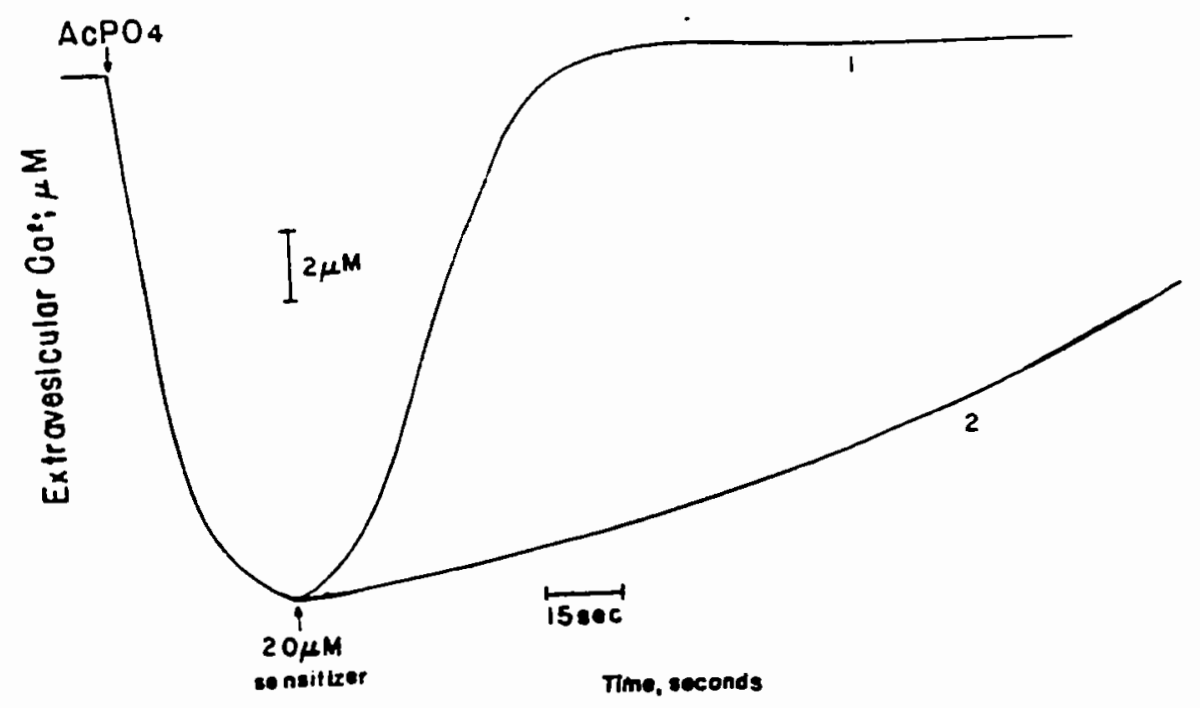

Figure 25. The effect of photooxidation-induced $\mathrm{Ca}^{2+}$ release from $\mathrm{SR}$ vesicles using erythrosin $\mathrm{B}$ and eosin $B$ as sensitizer. SR vesicles were actively loaded with $\mathrm{Ca}^{2+}$ as described in Figure 9. $\mathrm{Ca}^{2+}$ efflux was initiated by the addition of 20 uM of either (1) erythrosin B or (2) eosin B. 
Photooxidation of a histidyl residue increases the $\mathrm{Ca}^{2+}$ permeability of $\mathrm{SR}$ vesicles. This effect is not inhibited by ruthenium red. Photomodification of the SR is delayed in the presence of high concentrations of $\mathrm{Mg}^{2+}$ but the $\mathrm{Ca}^{2+}$ efflux rates are $\mathrm{Mg}^{2+}$ independent. EFA, another histidine modifying reagent, also increases $\mathrm{Ca}^{2+}$ permeability of $S R$ vesicles. EFA modification of $S R$ vesicles is inhibited by ATP similar to noncompetitive inhibition observed in enzyme kinetics indicating that the histidine is not part of the ATP binding site. EFA-induced maximal $\mathrm{Ca}^{2+}$ efflux rates are $\mathrm{Mg}^{2+}$ independent however, high concentrations of $\mathrm{Mg}^{2+}$ results in a delay of the initiation of efflux after the EFA has been added. Therefore, $\mathrm{Mg}^{2+}$ does afford some protection to $\mathrm{SR}$ vesicles treated with EFA.

SR derived from the terminal cisternae is only $40 \%$ more sensitive to photooxidation than longitudinal SR. The photooxidation effect is not on membrane lipids but on a protein component which may be an ion transport system, other than the $\mathrm{Ca}^{2+}$ release protein, altered in such a way that it now transports $\mathrm{Ca}^{2+}$. Hopefully, the data presented in this thesis will be used as a foundation for the study of different SR ion channels and their arrangement in the membrane. 


\section{REFERENCES}

1. Lehninger, A. L. (1982) Principles of Biochemistry. Worth Publisher, Inc., New York.

2. Stryer, L. (1981) Biochemistry, 2nd ed.. W. H. Freeman and Co., San Francisco.

3. Zubay, G. (1983) Biochemistry. Addison-Wesley Publishing Co., Menlo Park, California.

4. Weissmann, G. and Clarborne, R. (eds.) (1975) Cell Membranes: Biochemistry, Cell Biology, and Pathology. H. P. Publishing Co., New York.

5. Capaldi, R. A. (1974) Sci. Am. 230:26-33.

6. Singer, S. J. and Nicolson, G. L. (1972) Science 175:720-721.

7. Lodish, H. F. and Rothman, J. E. (1979) Sci. Am. $240: 48-63$.

8. Carafoli, E. (1987) Ann. Rev. Biochem. 56:395-433.

9. Campbell, A. K. (1986) Cell Calcium 7:285-295.

10. Martonosi, A. N. (1984) Physiological Reviews 64:124 1306.

11. Meissner, G. (1988) in Methods in Enzymology, v. 157 Part Q, Fleischer, S. and Fleischer, B., eds., Academic Press, pp 417-436.

12. Martonosi, A. N. (1982) in calcium and cell Function, vol. 3 Cheung, W. Y., ed., Academic Press, pp 37-102.

13. DeMeis, L. (1981) The Sarcoplasmic Reticulum Transport and Energy Transduction. Wiley-Interscience, New York.

14. Fairhurst, A. S., and Hasselbach, W. (1970) Eur. J. Biochem. 13: 504-509.

15. Lau, Y. H., Caswell, A. H., Brunschwig, J.P. (1977) J. Biol. Chem. 252: 5566-5574. 
16. Lau, Y.H., Caswell, A. H., Brunschwig, J.P., Baerwald, R. J., and Garcia, M. (1979) J. Biol. Chem. 254: 540546 .

17. Chu, A., Dixon, M.C., Saito, A., Seiler, S. and Fleischer, S. (1988) in Methods in Enzymology, v. 157 Part Q, Fleischer, $S$ and Fleischer, B., eds., Academic Press, pp 36-45.

18. Campbell, K. P. and Shamoo, A.E. (1980) J. Membr. Biol. 56: 241-248.

19. Meissner, G. (1975) Biochim.Biophys. Acta 389: 51-55.

20. Lai, F.A., Erichson, H.P., Rousseau, E., Liu, Q.Y., and Meissner, G. (1988) Nature 331: 315.

21. Mitchell, R. D., Palade, P., and Fleischer, S., (1984) J. Cell Biol. 96:875-885.

22. Trimm, J.L., Salama, G., and Abramson, J.J. (1986) J. Biol. Chem. 261: 16092-16098.

23. Meissner, G., Rousseau, E., Lai, F.A., Lin, Q.Y., and Anderson, K.A. (1988) Mol. Cell. Biochem. 82: 59-66.

24. Berman, M.C. (1982) Biochim, Biophys. Acta.694: 95121.

25. Schneider, M. F. (1981) Annu. Rev. Physiol. 43:507517.

26. Gilly, w. F. (1981) in The Regulation of Muscle Contraction: Excitation-Contraction coupling. Grinnell, A. D. and Brazier, M. A. B., eds., Academic Press, pp. 3-22.

27. Franzini-Armstrong, C., Heuser, J. E., Reese, T.S., Somlyo, A. P. and Somlyo, A. V. (1978) J. Physiol. London 283: $133-140$.

28. Schneider, M.F. and Chandler, W.K. (1973) Nature London 242: 244-246.

29. Baylor, S.M., Chandler, W.K., and Marshall, M.W. (1982) J. Physiol, London 331: 139-177.

30. Blinks, J.R., Prendergast, F.B., and Allen, D.G. (1976) Pharmacol. Rev. 28: 1-93.

31. Blinks, J.R., Wier, W.G., Hess, P., and Prendergast, F.G. (1982) Prog. Biophys. Mol. Biol. 40: 1-114. 
32. Ebashi, S. (1976) Annu. Rev. Physicol. 38: 293-311.

33. Ebashi, S., and Endo, M. (1968) Prog. Biophys. Mol. Biol. 18: 123-137.

34. Fabiato, A. (1982) Can. J. Physiol. Pharmacol. 60: 556-567.

35. Eisenberg, E., and Greene, L.E. (1980) Annu. Rev. Physiol. 42: 293-309.

36. Lymn, R.W. (1979) Annu. Rev Biophys. Bioenerg. 8: 145163.

37. Fabiato, A. and Fabiato, F. (1979) Annu. Rev. Physiol. 41: $476+484$.

38. Chandler, W. K., Rakowsky, R. F. and Schneider, M. F., (1976) J. Physiol. London 254: 285-316.

39. Horowicz, P. and Schneider, M. F. (1981) J. Physiol. London 314: 565-596.

40. Horowicz, P. and Schneider, M. F. (1981) J. Physiol. London 314:595-633.

41. Ohnishi, S. T. (1979) J. Biochem, Tokyo 86:1147-1150.

42. Fabiato, A. (1981) in The Mechanism of Gated Calcium Transport Across Biological Membranes, Ohnishi, S. E. and Endo, M., eds. Academic Press, pp.237-255.

43. Stephenson, E, W. (1982) Can. J. Physiol. Pharmacol. $60: 417-426$.

44. Stephenson, E. W. (1981) Am. J. Physiol. 240: C1-C19.

45. Bianchi, C.P., and Bolton, T.C. (1966) J. Pharmacol. Exp. Ther. 151: 456-463.

46. Bianchi, C. P. and Bolton, T.C. (1967) J. Pharmacol. Exp. Ther. 157: 388-405.

47. Endo, M., Tanaka, M. and Ogawa, Y. (1970) Nature London 228: $34-36$.

48. Ford, L.E. and Podolsky, R.J. (1970) Science 167: 5869. 
49. Endo, M. (1981) in The Mechanism of Gated Calcium Transport Across Biological Membranes, Ohnishi, S. T. and Endo, M., eds., Academic Press, pp 257-264.

50. Fabiato, A. (1982) Federation Proc. 41: 2238-2244.

51. Winegrad, S. (1982) Annu. Rev. Physiol. 44: 451-462.

52. Fabiato, A. and Fabiato, F. (1979) Nature London 281: 146-148.

53. Miyamoto, H., and Racker, E. (1981) FEBS Lett. 133: $235-238$.

54. Miyamoto, H., and Racker, E. (1982) J. Membr. Biol. 66: 193-201.

55. Ohnishi, S. T. (1981) in The Mechanism of Gated Calcium Transport Across Biological Membranes. Ohnishi, S. T. and Endo.M., eds., Academic Press, pp. 275-293.

56. Meissner, G. (1983) Mol. Cell. Biochem. 55: 65-75.

57. Nagasaki, K., and Kasai, M. (1983) J. Biochem. Tokyo 94: 1101-1109.

58. Morii, H., and Tonomura. (1983) J. Biohchem. Tokyo $93: 1271-1285$.

59. Endo, M. (1977) Physiol. Rev. 57: 71-108.

60. Endo, M., Kakuta, Y., and Kitazawa, T. (1981) in The Regulation of Muscle Contraction: ExcitationContraction Coupling. Grinnell, A. D. and Brazier, M. A. B., eds., Academic Press, pp. 181-195.

61. Frank, G. B. (1982) Can. J. Physiol. Pharmacol. $60: 427-439$.

62. Kirino, Y., Osakabe, M., and Shimizu, H. (1983) J. Biochem. Tokyo 94: 1111-1118.

63. Ogawa, Y., and Ebashi, S. (1976) J. Biochem. Tokyo $80: 1149-1157$.

64. Ogawa, Y., Kurebayashi, N., and Harafuji, H. (1981) in The Mechanism of Gated Calcium Transport Across Biological Membranes, Ohnishi, S. T., and Endo, M., eds., Academic Press, pp. 265-273.

65. Endo, M. (1975) Proc. Jpn. Acad. 51: 479-484. 
66. Ford, L.E., and Podolsky, R.J. (1972) J. Physiol, London 223: 1-19.

67. Kirino, Y., and Shimizu, H. (1982) J. Biochem. Tokyo 92 : $1287-1296$.

68. Meissner, G. (1984) J. Biol. Chem. 259: 2365-2374.

69. Smith, J.S., Coronado, R., and Meissner, G. (1986) J. Gen Physiol.88: 573-588.

70. Meissner, G. (1986) Biochemistry 25: 244-251.

71. Endo, M. (1977) Physiol. Rev. 57: 71.

72. Dupont, Y. (1977) Eur. J. Biochem. 72: 185-190.

73. Somlyo, A.V. (1979) J. Cell Biol. 80: 743-750.

74. Somlyo, A.V., Gonzales-Serrator, H.G., Shuman, H., Mcclellan, G., and Somlyo, A.P. (1981) J. Cell Biol. 90: 577-594.

75. Beeler, T., Russell, J. T., and Martonosi, A. (1979) Eur. J. Biochem. 95: 579-591.

76. Meissner, G., and McKinley, D. (1976) J. Membr. Biol. 30: 79-98.

77. Martonosi, A., and Feretos, R. (1965) J. Biol. Chem. 239: 648-658.

78. Bindoli, A., and Fleischer, S. (1983) Arch. Biochem. Biophys. 221: 458-466.

79. Abramson, J.J., Trimm, J.L., Weden, L., and Salama, G. (1983) Proc. Natl. Acad. Sci. USA 80: 1526-1530.

80. Chiu, V.C.K., Mouring, D., and Haynes, D.H. (1983) J. Bioenerg. Biemembr. 15: 13-25.

81. Stuart, J., and Abramson, J. J. (1988) Arch. Biochem. and Biophysics. 264: 125-134.

82. Abramson, J. J., Cronin, J. R., and Salama, G. (1988) Arch. Biochem. Biophys. 263: 245-255.

83. Abramson, J. J., Buck, E., Salama, G., Casida, J. E., and Pessah, I. N. (1988) J. Biol. Chem., 263:1875018758 . 
84. Ferrans, V.F. (1978) Cancer Treat. Rep. 62: 955-961.

85. Zarzato, F., Salviati, G., Fachinetti, T., and Volpe, P. (1985) J. Biol. Chem. 260: 7349-7355.

86. Shoshan-Barmatz, V. (1987) Biochem. J. 243: 165-173.

87. Tenu, J.P., Ghelis, C., Leger, D.S. and Carreite, J. (1976) J. Biol. Chem. 254: 4323-4329.

88. Yu, B.P., Masoro, R.J., and Bertrand, H.A. (1974) Biochemistry 13: 5083-5087.

89. Martonosi, A, Boland, R. and Halpin, R. A. (1972) Cold Spring Harper Symp., Quart. Biol. 37:455-468.

90. Kondo, M. and Kasai, M (1974) Photochem. Photobiol. $19: 35-41$.

91. Caswell, A. H., Brandt, N. R., Brunschwig, J. P., and Kawamoto, R. M. (1988) in Methods in Enzymology, $v$. 157 Part Q, Fleischer, S. and Fleischer, B., eds., Academic Press, pp 68-84.

92. Lau, Y. H., Caswell, A. H., and Brunschwig, J. P. (1977) J. Biol. Chem. 252: 5565.

93. Meissner, G. (1986) J. Biol Chem. 261:6300-6306.

94. Pessah, I. N., Stambuk, R. A., and Casida, J.E. (1987) Molec. Pharmacol. 31: 232-238.

95. Pessah, I. N., Francini, A. O., Scales, D. J., Waterhouse, A. L., and Casida, J. (1986) J Biol. Chem. $62: 8643-8648$.

96. Chadwick, C. C., Inui, M. and Fleischer, S. (1988) J. Biol. Chem 263:10872-10877.

97. Meissner, G., Rousseau, E. and Lai, F. A. (1989) J. Biol. Chem. 264:1715-1722.

98. MacLennan, D. H. (1970) J. Biol. Chem. 245:4508-4518.

99. Kalckar, H. M. (1947) J. Biol. Chem. 196:461-475.

100. Chance, B., Legallais, V., Sorge, J., and Graham, N. (1975) Anal. Biochem. 66:498-514.

101. Means, G. E. and Feeney, R. E. (1971) Chemical Modification of Proteins. Holden-Day, Inc., San Francisco. 
102. Muhlrad, A., Hegyi, G. and Horanyi, M. (1969) Biochim. Biophys. Acta. 181:184-189.

103. Tipton, K. F. (1978) Techniques in Protein and Enzyme Biochemistry, B112. The Netherlands: Elsevier/NorthHolland Biomedical Press, pp 5-9.

104. Laemmli, U. K. (1970) Nature 227:680-685.

105. Kraljic, J., Mohsni, S. E. and Arvis, M (1978) Photochem. Photobiol. 27:531-537.

106. Ohnishi, S. (1979) J. Biochem. 86:1147-1150.

107. Su, J. Y., and Hasselbach, W. (1984) Pflugers Arch. $400: 14-21$.

108. Millman, M. S., and Azari, J. (1977) Biochem. Biophys. Res. Commun. 78:60-66.

109. Smith, J. S., Coronade, R., and Meissner, G. (1985) Nature (London) 316:446-449.

110. Abramson, J. J., Trimm, J. L., Weden, L., and Salama, G., (1983) Proc. Natl. Acad. Sci. USA 80:1526-1530.

111. Yamamoto, N., and Kasai, M. (1982) J. Biochem. 92:485496.

112. Meissner, G., Darling, E., and Eveleth, J. (1986) Biochenistry 25:236-244.

113. Arrondo, J. L. R., Urbaneja, M. A., Goni, F. M., Macarulia, J. M., and Sarzala, G.- (1985) Biochem. Biophys. Res. Commun. 128:1159-1163

114. Salama, G., and Abramson, J. (1984) J. Biol. Chem. 259:13363-13369.

115. Pooler, J. P. and Valenzeno, D. P. (1979) Photochem. Photobiol. 30:581-584.

116. Pooler, J. P. and Valenzeno, D. P. (1979) Photochem. Photobiol. 30:491-498.

117. Pooler, J. P. and Girotta, A. W. (1986) Photochem. Photobiol. 44:495-499.

118. Pooler, J. P. (1988) Photochem. Photobiol. 47:369-376. 
119. Nigg, E., Kessller, M. and Cherry, R. J. (1979) Biochim. Biophy. Acta 550-328-340.

120. Morris, S. J., Silbergeld, E. K., Brown, R. R., and Haynes, D. H. (1982) Biochem. Biophys. Res. Commun. 104:1306-1311.

121. Watson, B. D. and Haynes, D. H. (1982) Chem. Biol. Interact. 41:313-325.

122. Ray, W. J., Jr. and Koshland, D. E., Jr. (1962) J. Biol. Chem. 237:2493-2505.

123. Morii, H. and Tonomura, Y. (1983) J. Membr. Biol. $66: 1993-2001$.

124. Nagura, S., Kawasaki, T., Taguchi, $T$ and Kasai, $M$. (1988) J. Biochem. 104:461-465.

125. Zaidi, N. F., Lagenaur, C. F., Abramson, J. J., Pessah, I. N., and Salama, G. (1988) J. Biol. Chem., submitted.

126. Shoshan-Barmatz, V. (1986) Biochem. J. 240:509-517.

127. Neckers, D. C. (1987) J. Chem. Education 64:649-656.

128. Meissner, G. and Allen, R. (1981) J. Biol. Chem. 256: 6413-6419.

129. Argaman, A. and Shoshan-Barmatz, V. (1988) J. Biol. Chem. 263:6315-6321.

130. Degani, C. and Boyer, P. D. (1973) J. Biol. Chem. $248: 8222-8226$.

131. Bastidi, F., Meissner, G., Fleischer, S. and Post, R. L. (1973) J. Biol. Chem. 248:8385-8391.

132. Coffey, R. L., Lagwinska, E., oliver, M., and Martonosi, A. (1975) Arch. Biochem. Biophys. 170:3748 .

133. Brocklehurst, K. (1979) Int. J. Biochem. 10:259-274.

134. Brocklehurst, K. (1974) Tetrahedron 30:2397-2407.

135. Lewis, S. D., Johnson, F. A. and Shafer, J. A. (1981) Biochemistry 20:48-51.

136. Valaitis, A. P., Roe, L. G. and Kemp, R. G. (1987) J. Biol. Chem. 262:5044-5048. 
137. Tsai, C. S., Wand, A. J., Godin, J. R. P., and Buchanan, G. W. (1982) Arch. Biochem. Biophys. 217: 721-729.

138. Mol, J. A., Docter, R., Hennemann, G. and Visser, T.J. (1984) Biochem. Biophys. Res. Commun. 120:28-36.

139. Cole, S. C. J., and Yon, R. J. (1986) Biochemistry 25: 7168-7174.

140. Miller, C. and Rosenberg, R. L. (1979) Biochemistry $18: 1138-1146$.

141. Cukierman, S., Yellen, G. and Miller, C. (1985) Biophys. J. 48:477-484.

142. Coronado, R., Rosenberg, R. L. and Miller, C. (1980) J. Gen. Physiol. 76:425-446.

143. Miller, C. (1982) J. Gen. Physiol. 79:869-891.

144. Garcia, A. M., Miller, C. (1984) J. Gen. Physiol. 83:819-839.

145. Kasai, M. (1981) J. Biochem. 89:943-953.

146. Grinstein, S. and Rothstein (1978) Biochim. Biophys. Acta $508: 236-245$.

147. Lukacovic, M. F., Toon, M. R. and Solomon, A. (1984) Biochim. Biophys. Acta 772:313-320.

148. Fabiato, A and Fabiato, F. (1979) J. Physiol., Paris. 75:463-505. 